Universidade de Brasília - UnB

Faculdade de Ciência da Informação - FCI

Programa de Pós-Graduação em Ciência da Informação - PPGClnf

A BIBLIOTECA ESCOLAR NOS PROJETOS DE LEITURA NAS ESCOLAS QUE OBTIVERAM OS MELHORES RESULTADOS DO ENEM

DISSERTAÇÃO DE MESTRADO

FLOR DE MARIA SILVESTRE ESTELA

Brasília

Março 2015 


\section{A BIBLIOTECA ESCOLAR NOS PROJETOS DE LEITURA NAS ESCOLAS QUE OBTIVERAM OS MELHORES RESULTADOS DO ENEM}

Dissertação de mestrado apresentada ao Programa de Pós-Graduação em Ciência da Informação (PPGCInf) da Universidade de Brasília (UnB), sob orientação da professora Dra. Kelley Cristine Gonçalves Dias Gasque, como requisito parcial para obtenção do título de mestre em Ciência da Informação. 
Ficha catalográfica elaborada pela Biblioteca Central da Universidade de Brasilia. Acervo 1020714

Silvestre Estela, Flor de Maria.

S587b A biblioteca escolar nos projetos de leitura nas escolas que obtiveram os melhores resultados do Enem / Flor de Maria Silvestre Estela. .- 2015.

$126 \mathrm{f}$. : il. ; $30 \mathrm{~cm}$.

Dissertaçăo (mestrado) - Universidade de Brasilia, Faculdade de Cie̊ncia da Informaçăo, Programa de Pós-Graduação em Ciência da Informaçăo, 2015.

Inclui bibliografia.

Orientaçăo: Kelley Cristine Gonçalves Dias Gasque.

1. Exame Nacional do Ensino Médio (Brasil). 2. Bibliotecas escolares. 3. Competências em informaçăo. 4. Compreensăo na leitura. I. Gasque, Kelley Crist ine Gonçalves Dias. II. Titulo. 


\section{FOLHA DE APROVAÇÃO}

Título: "A biblioteca escolar nos projetos de leitura nas escolas que obtiveram os melhores resultados do Enem"

\section{Autor (a): Flor de María Silvestre Estela}

Área de concentração: Gestão da informação

Linha de pesquisa: Organização da Informação

Dissertação submetida à Comissão Examinadora designada pelo Colegiado do Programa de Pós-graduação em Ciência da Informação da Faculdade em Ciência da Informação da Universidade de Brasilia como requisito parcial para obtenção do título de Mestre em Ciência da Informação.

Dissertação aprovada em: 05 de março de 2015.

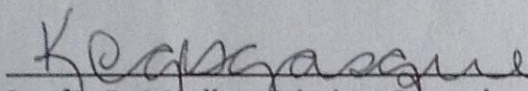

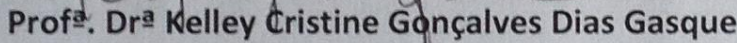
Presidente (UnB/PPGCINF)

Profa. Dr Janaina Ferreira Fialho Membro Externo (UFS)

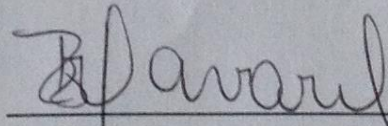

Profa. Dra. Rosemeire Barbosa Tavares

Membro Interno (UnB/PPSCINF)

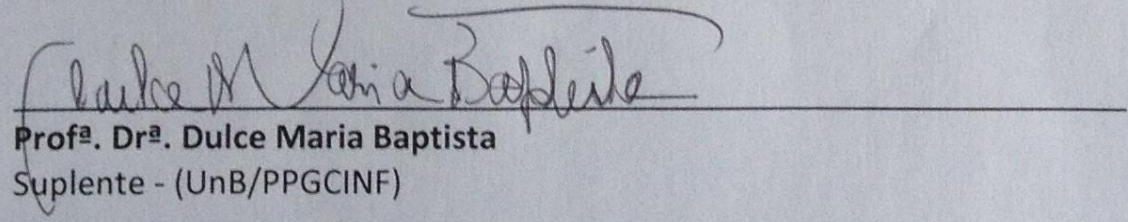


Deus e a vida sempre oferecem uma segunda oportunidade. Aprendi na vida a lutar pelos nossos sonhos e a pegar essa segunda oportunidade. Não foi fácil deixar meu país, meus pais, minha família e amigos, para continuar este longo e distante caminho da vida acadêmica no Brasil, país que gosto muito.

Dedico esta pesquisa,

ao meu pai, Pascual Silvestre Estrada, em memória, que confiou em minha capacidade e cujo maior desejo era minha felicidade e que agora descansa no céu com Deus.

a minha mãe, Alicia Estela Mendoza, por suas palavras de alento, pelo apoio constante tanto em meu país e via internet aqui no Brasil.

ao meu sobrinho, Minoru Muaro Silvestre, por sua luta constante no que empreende na vida, com muito carinho e agradecimento, dando mostra de que na vida tudo se pode fazer.

a minha irmã, Rosário Silvestre Estela e a minha afilhada Angellie, por sua dedicação e cuidado aos meus pais, por darme apoio familiar e fazer-me saber que posso contar com elas em qualquer situação da vida. 


\section{AGRADECIMENTOS ESPECIAIS}

À Professora Kelley Cristine Gasque que é uma referência positiva em minha vida profissional. Ela é mais que uma orientadora: é uma amiga e um modelo a seguir. Eu podia estar confusa com muitas ideias e ela tem o dom de escutar-me e ter a solução. Agradeço pelo estágio maravilhoso e inesquecível que realizei com ela e com o qual aprendi muito. Agradeço ainda por dispor de seu tempo para compreender meu "portunhol", por suas horas de dedicação a minha pesquisa. Por confiar em mim, fico eternamente agradecida. Por suas constantes palavras de alento. Por estar presente comigo na minha vida acadêmica e pessoal. Deus a abençoe muito, para que siga compartilhando com seus orientados todos os seus conhecimentos.

Ao Professor Fernando Leite, por ser meu tutor aqui em Brasília e pelo apoio incondicional em minha estadia. Por suas palavras de reflexão e pela imagem de professor amigo que transmite.

Conheci pessoas maravilhosas com uma luz especial. Uma dessas pessoas é Humberto Borges, que compartilha comigo a amizade, o tempo, os conhecimentos da língua portuguesa, bem como a cultura e os costumes do Brasil. Agradeço a Deus pela oportunidade de conhecê-lo. Agradeço a outro grande amigo, Wildes Andrade, que foi meu primeiro amigo brasileiro e quem abriu as portas de sua casa. Fez minhas primeiras correções sempre atento às atividades de minha vida e, em especial, a minha vida acadêmica. Tenho neles uma segunda família, sempre atentos a minha estadia em Brasília apoiando-me constantemente com minha pesquisa.

A minhas amigas da Colina, bloco $\mathrm{K}$, moradia de estudantes da UnB, o inesquecível apartamento 305. A minha querida amiga Andressa Dantas de Silveira por fazerme sentir em família e achar uma irmã nela. A Christe Elida Montontijo por sua parceria em todos os aspetos de minha vida, minha grande amiga. A Elaine Silva que na etapa final da presente pesquisa foi uma parceira nas noites de escrita, uma grande pessoa entusiasta da vida acadêmica. A Carolina Alzate e Mauro Gouveira pela amizade incondicional.

A todas as pessoas que, de uma ou outra maneira, contribuíram para fazer minha estadia em Brasília muito confortável. Às pessoas que, com seus conselhos e orientações, apoiaram-me para o desenvolvimento desta pesquisa Patrícia Coria 
(México), Sandra Leal (Colômbia), Jehyra Asencio (Porto Rico), Judith Quispe (Peru), Lissette Marie Campos (Peru), Neri Regina, Reginita e um agradecimento especial ao professor Alejandro Cussianovich, por estar sempre me orientando na vida.

A Ada Sosa e Julio Santillan por compartilharem meus sonhos e pelo apoio no trajeto e processo de continuar meus estudos de pós-graduação no Brasil. Meus melhores desejos para eles no que empreendam na vida.

Às professoras que fazem parte desta banca: Dulce Maria Baptista, Janaina Ferreira Fialho, Rosemeire Barbosa Tavares, pela dedicação em favor das pesquisas da faculdade, pela disponibilidade e recomendações.

Aos funcionários da Faculdade de Ciências da Informação da Universidade de Brasília, pelo bom trato e disponibilidade aos estudantes. 


\section{RESUMO}

A pesquisa analisa a contribuição dos projetos de leitura das bibliotecas escolares das escolas que obtiveram os primeiros lugares no ranking do Enem de 2013, no Distrito Federal. Os objetivos específicos são descrição da proposta pedagógica e da estrutura das escolas; descrição da estrutura, dos produtos e os serviços oferecidos pelas bibliotecas escolares; identificação dos projetos de leitura e contribuição para o desenvolvimento de competências leitoras; e, por fim, identificação da relação entre docente e bibliotecário nos projetos de leitura. A metodologia tem natureza quali-quantitativa. A amostra abrangeu seis escolas, sendo três privadas e três públicas. Os resultados mostram que os projetos de leitura vinculados às disciplinas lecionadas pelos professores pesquisados, em geral, são realizados sem participação das bibliotecas escolares. Contudo, os professores relataram que as bibliotecas escolares contribuíram para os resultados do Enem em outros aspectos, tais como: oferta de acesso à informação organizada, horário de atendimento adequado e recursos humanos.

Palavras-chave: Biblioteca Escolar. Centro de Recurso de Aprendizagem. Leitura. Competências Leitoras. Enem. 


\section{ABSTRACT}

This research analyses the contribution of reading projects at school libraries of schools that obtained the first places in the 2013 Enem ranking. The specific objectives are the description of the educational proposal and structure of the surveyed schools; the description of the structure of the products and services offered by the school libraries; the identification of reading projects and its contribution to the development of reading skills, and finally, identifying the relationship between the teacher and the librarian in reading projects. The research uses a quali-quantitative methodology. The sample focused in six schools, three private and three public. The results show that the reading projects linked to school subjects in general are carried out without the participation of school libraries. However, teachers reported that school libraries have contributed to the result of Enem in other ways, such as providing access to information and good space and time to attend students, and also human resources.

Key words: Library school. Learning Resource Center. Reading. Reading skills. Enem. 


\section{LISTA DE ABREVIAÇÕES}

\begin{tabular}{|c|c|}
\hline AASL & American Association of School Libraries \\
\hline ACE & Avaliação das Condições de Ensino \\
\hline ACRL & Association of College and Research Library \\
\hline ENEM & Exame Nacional do Ensino Médio \\
\hline PISA & $\begin{array}{l}\text { Programme for Internacional Student Assessment (Programa } \\
\text { Internacional de Avaliação do Desempenho dos Alunos) }\end{array}$ \\
\hline OCDE & Organização para a Cooperação e Desenvolvimento Económico \\
\hline BE & Biblioteca Escolar \\
\hline IFLA & International Federation of Library Associations and Institutions \\
\hline INEP & $\begin{array}{l}\text { Instituto Nacional de Estudos e Pesquisas Educacionais Anísio } \\
\text { Teixeira }\end{array}$ \\
\hline AECT & Association for Educational Communications and Technology \\
\hline DCN & Diretrizes Curriculares Nacionais \\
\hline SAEB & Sistema de Avaliação da Educação Básica \\
\hline IDEB & Desenvolvimento da Educação Básica \\
\hline ALA & American Library Association \\
\hline LI & Letramento informacional \\
\hline CFB & Conselho Federal de Biblioteconomia \\
\hline GEBE & Grupo de Estudos em Biblioteca Escolar \\
\hline UFMG & Universidade Federal de Minas Gerais \\
\hline EJA & Educação de Jovens e Adultos \\
\hline PAS & Programa de Avaliação Seriada \\
\hline DF & Distrito Federal \\
\hline
\end{tabular}




\section{LISTA DE QUADROS E TABELAS}

Quadro 1 - Os princípios de ação pedagógica do currículo 20

Quadro 2- Competências na redação do Enem 2013

Quadro 3 - Letramento informacional para o aprendizado do aluno. 25

Quadro 4 - Competência, leitura da informação e indicadores. 27

Quadro 5 - Estratégias de leitura (Texto adaptado para o formato de figura e $\quad 30$ tradução nossa do espanhol)

Quadro 6 - Paradigmas da biblioteca escolar. 31

Quadro 7 - instrumentos de coleta de dados. $\quad 42$

Quadro 8 - Padrões da avaliação da BE segundo Grupo de Estudos em 43

Biblioteca Escolar (GEBE) da UFMG

Quadro 9- Ranking das escolas pesquisadas 48

Quadro 10- Rótulos de identificação das escolas participantes da pesquisa 63

Quadro 11- Funcionamento das bibliotecas pesquisadas 65

Quadro 12 - Horário de funcionamento das bibliotecas pesquisadas 66

Quadro 13: Condições do espaço físico 68

Quadro 14: Espaços existentes na biblioteca 69

Quadro 15: Mobiliário e equipamentos $\quad 69$

Quadro 16. Organização do acervo 72

Quadro 17 - Condições gerais do acervo 73

Quadro 18 - Serviços e atividades. 74

Tabela 1: Localização e metragem das bibliotecas pesquisadas 67

$\begin{array}{ll}\text { Tabela 2- computadores } & 70\end{array}$

Tabela 3- Dados quantitativo do acervo $\quad 71$

Tabela 4: Funcionários da biblioteca 75 


\section{LISTA DE ILUSTRAÇÕES}

Figura 1 - Enfoques de leitura. $\quad 28$

Figura 2 - Processo de projeto de leitura. $\quad 37$

Figura 3 - Referencial teórico $\quad 40$

Figura 4 - Processo de projeto de leitura 99

Gráfico 1 - Formação acadêmica e tipo de colégio. 64

Gráfico 2 - Gênero e área do conhecimento 64

Gráfico 3 - Concepção de BE dos professores 78

Gráfico 4 - Planejamento das atividades de leitura 78

Gráfico 5 - Materiais de consulta da BE 79

Gráfico 6 - Parcerias e frequência entre a BE e os professores 80

Gráfico 7 - Estratégias de leitura mais utilizadas na promoção da leitura 81

Gráfico 8 - Tipos de leitura mais utilizados e frequência de uso. 81

Gráfico 9A - Atividades desenvolvidas na BE 82

Gráfico 9B - Atividades desenvolvidas na BE 83

Gráfico10- BE contribuição no Enem 84

Fotografia 1 - Pátio da escola - Vértice 49

Fotografia 2 - Biblioteca - Vértice 50

Fotografia 3 - Sala de cotações - Vértice $\quad 51$

Fotografia 4- Frente da escola - Galois 52

Fotografia 5 - Cabines de estudo - Galois 54

Fotografia 6 - Prédio da 3ª̣ série do Ensino Médio e visão parcial da área 55 verde do SIGMA

Fotografia 7 - Biblioteca - Sigma 56

Fotografia 8 - Frente da escola - Colégio Militar 57

Fotografia 9 - Balcão de atendimento - Colégio Militar 58

Fotografia 10 - Frente da escola - CEMSO 59

Fotografia 11- Sala de consulta - CEAN 62 


\section{SUMÁRIO}

I. INTRODUÇÃO 14

1.1. Definição do problema 15

$\begin{array}{ll}1.2 \text { Objetivos geral } & 17\end{array}$

$\begin{array}{ll}1.3 \text { Objetivos específicos } & 17\end{array}$

$\begin{array}{ll}1.4 \text { Justificativa } & 17\end{array}$

II. REVISÃO DE LITERATURA

2.1 Educação Básica - Enem 19

2.1.1 Avaliação do Ensino Médio 21

2.2 A leitura como Competência no Letramento Informacional 23

2.2.1 Leitura - Competências leitoras $\quad 27$

2.3 Biblioteca Escolar - Centro de Recursos de Aprendizagem 30

2.3.1 Promoção da leitura no CRA 33

III. METODOLOGIA DA PESQUISA

3.1 Referencial Teórico 38

3.2 Descrições da Pesquisa $\quad 41$

3.2.1 Instrumento de coleta de dados $\quad 41$

3.2.1.1 Análise documental 42

3.2.1.2 Formulário dos padrões da GEBE-UFMG 42

3.2.1.3 Questionário 44

3.2.2 Caracterização da Amostra 45

\section{ANÁLISE DOS RESULTADOS}

4.1 Análise documental $\quad 49$

4.1.2 Colégio Vértice - São Paulo 49

4.1.3 Colégio Galois $\quad 52$

4.1.4 Centro Educacional Sigma

4.1. 5 Colégio Militar de Brasília 57

4.1. 6 Centro de Ensino Médio Setor Oeste 59

4.1.7 Colégio CEAN - Asa Norte 61

4.2 Análise dos formulários e questionários 62

4.2.1. Características demográficas dos participantes 63

4.2.1.1 Bibliotecários funcionários 63

4.2.1.2 Gênero 64 
4.3.1. Funcionamento das bibliotecas 65

4.3.2 Categoria espaço físico 66

4.3.2.1 Localização e metragem das bibliotecas 66

4.3.2.2 Condições observadas nas bibliotecas $\quad 67$

4.3.2.3 Espaços existentes na biblioteca 68

4.3.3 Mobiliário e equipamentos $\quad 69$

4.3.3.1. Computadores 70

4.3.4 Acervo 70

4. 3.4.1 Organização da coleção 71

4.3.4.2 Condições gerais do acervo $\quad 72$

4.3.5 Categoria serviços e atividades 73

4.3.6 Pessoal 74

4.4. Resultado dos questionários 76

4.4.1 Categoria: relação entre o docente e a BE nos projetos de leitura 77

4.4.2 Competências leitoras e estratégias de leitura 80

4.4.3 Percepção sobre a contribuição da BE para os resultados do Enem 83

\section{DISCUSSÃO DOS RESULTADOS}

5.1 Estrutura e proposta pedagógica dos colégios pesquisados 85

5.2 Estrutura, produtos e os serviços oferecidos pela biblioteca 86 escolar das escolas pesquisadas

5.3 Projetos de leitura e a contribuição da biblioteca escolar 91 para a formação de competências leitoras

5.4 Relação entre o docente e o bibliotecário nos projetos de leitura. 94

VI. CONCLUSÕES E RECOMENDACÕES 97

REFERÊNCIAS 101

$\begin{array}{ll}\text { Apêndice Modelo de questionário } & 106\end{array}$

Anexo1 Parâmetros para BE - GEBE 111

$\begin{array}{ll}\text { Anexo2 Guia da prova de redação do Enem } & 123\end{array}$ 


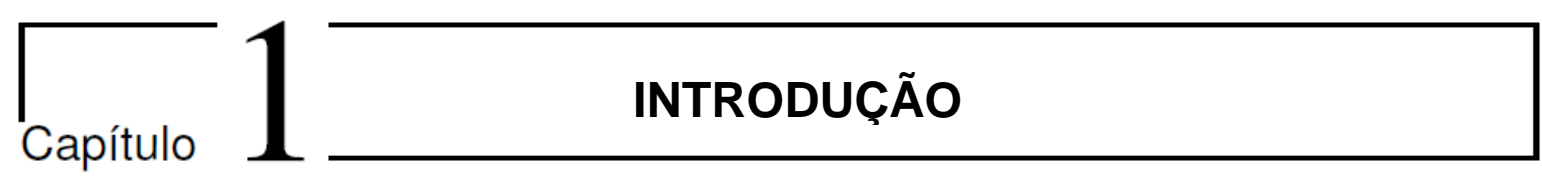

A presente pesquisa pretende contribuir para o desenvolvimento da Ciência da Informação ao verificar a configuração das bibliotecas escolares (BE) e como elas promovem as competências leitoras, recursos indispensáveis que os estudantes precisam dominar para fazer frente à avalanche de informação. Para tanto, parte-se de dois pressupostos: (i) a concepção da BE transcende a de depositária de livros ao se converter em um Centro de Recursos de Aprendizagem para poder auxiliar na aprendizagem dos estudantes. Nessa parte, consideram-se os aportes teóricos de Gasque (2013), CERLALC (2007) e OEA (1985), que utilizam elementos, critérios e experiências de integração da BE com a proposta pedagógica da escola; e (ii) a prática das competências leitoras contribui para o desenvolvimento de estratégias de leitura que possibilitam aos estudantes recursos básicos para fazer frente às análises e à interpretação da informação. São utilizados como teóricos Cuevas (2007), Cuevas e Simeão (2011) e Solé (2004), por argumentarem sobre a importância da consolidação das competências leitoras no processo de letramento informacional.

A partir desses pressupostos desenvolve-se a proposta de que a $\mathrm{BE}$, em integração com o docente inserido no projeto educativo da escola, converte-se em ator dinâmico no contexto educacional, fato que a consolida como centro de recursos de aprendizagem. Cuevas $(2007$, p.3) argumenta que "a sociedade do conhecimento procura uma reorientação no modelo da biblioteca escolar que a transforme em centro de recursos para a aprendizagem e em componente essencial da educação". Nesse contexto, a BE pode promover atividades fundamentadas na animação e promoção das competências leitoras nos estudantes. Solé (2004, p. 37) afirma que "conhecer variadas estratégias que promovam a compreensão e abordar as tarefas de leitura que exijam utilizá-las é chave para fomentar a leitura compreensiva, crítica e epistêmica". A leitura apresenta-se como uma ferramenta que vai além da decodificação do texto, pois dota de conhecimentos e competências os leitores que interagem com um texto. A leitura é compreendida como um exercício completo que se desenvolve no processo cognitivo para ser aplicado em contextos sociais. 
A pesquisa organiza-se em seis capítulos. O primeiro consta de uma breve introdução com apresentação do problema, objetivos e justificativa. No capítulo dois, há a descrição de conceitos que proporcionam visão mais clara da proposta da pesquisa. Nesse capítulo, intitulado Educação Básica e o Enem, apresenta-se como se desenvolvem as provas de redação e como a leitura se insere como competência informacional no contexto do letramento informacional. Além disso, apresenta-se a relação entre padrões do letramento informacional e as competências leitoras, visto que se vinculam com a capacidade de análise e o uso de estratégias leitoras para a interpretação de textos. A BE aparece como um Centro de Recurso de Aprendizagem, expressão que designa a nova concepção de biblioteca escolar, mais dinâmica e atuante no processo de aprendizagem, com a responsabilidade de estimular a leitura e dar suporte ao desenvolvimento das competências leitoras.

O capítulo três abrange a metodologia de pesquisa, que inclui o referencial teórico, a amostra e a coleta de dados. Essa última divide-se em três seções. $\mathrm{Na}$ primeira seção, realizou-se a pesquisa documental da escola com a finalidade de conhecer o projeto e a estrutura pedagógica das seis primeiras escolas do ranking do Enem 2013. O segundo instrumento foi um formulário aplicado para avaliação da $\mathrm{BE}$. O formulário foi construído de acordo com os padrões propostos pelo Conselho Federal de Biblioteconomia (CFB) e pelo Grupo de Estudos em Biblioteca Escolar (GEBE) da Escola de Ciência da Informação da Universidade Federal de Minas Gerais (UFMG). O terceiro instrumento foi a aplicação de questionários aos docentes que trabalham em projetos de leitura nas escolas pesquisadas.

O capítulo quatro apresenta a análise dos resultado, o capítulo cinco apresenta a discussão dos resultados organizados de acordo com os objetivos específicos da pesquisa, e por fim, o último capítulo trata das conclusões e recomendações.

\subsection{Definição do problema}

Os paradigmas em relação à informação e ao conhecimento mudaram nos séculos XX e XXI. Em consequência da grande quantidade de informação circulante, surgem novas formas de aprendizagem e competências, que os estudantes devem 
desenvolver nas escolas para o pleno exercício dos direitos fundamentais ao longo da vida.

Avaliações recentes mostram que os estudantes brasileiros possuem baixos níveis de desenvolvimento de competências em compreensão e interpretação leitora. Segundo dados do Programa Internacional de Avaliação de Alunos (PISA), de 2012, o desempenho dos estudantes brasileiros em leitura piorou em relação a 2009. O país somou 410 pontos em leitura, dois a menos do que a pontuação alcançada na última avaliação, e 86 pontos abaixo da média dos países da Organização para Cooperação e Desenvolvimento Econômico $\left(\mathrm{OCDE}^{1}\right)$. Com isso, o país ficou com a 55a posição do ranking de leitura entre 65 países. Quase metade dos estudantes brasileiros (49,2\%) não alcançou o nível dois (02) de desempenho na avaliação, que tem o nível seis (06) como pontuação máxima. Isso significa que esses estudantes não são capazes de deduzir informações do texto, de estabelecer relações entre diferentes partes do texto e não conseguem compreender o texto, segundo informe da OECD (2012, p. 2-3).

Tais resultados refletem-se na avaliação do Exame Nacional do Ensino Médio (Enem), especificamente na prova de redação, em que os estudantes precisam escrever um texto a partir de ideias gerais. Os espelhos de correção da redação do Enem, de 2013, apresentaram os seguintes resultados: dos 5.049.248 textos corrigidos, 481 tiveram nota mil. Houve 32.991 em branco e outros 73.751 foram anulados. O saldo foi de 106.742 redações com nota zero e poucos textos com nota máxima (UOL, 2014).

As Avaliações, como PISA e Enem, mostram que os estudantes brasileiros apresentam baixos níveis de desenvolvimento de competências em compreensão e interpretação leitora. Diante dessa situação, as bibliotecas escolares, atuantes como Centro de Recursos de Aprendizagem, podem se converter em aliadas principais na promoção das competências leitoras.

Cuevas (2007, p.5) afirma que a sociedade atual precisa migrar do modelo de Biblioteca Escolar tradicional - centrada no acesso à informação - para o de Centro de Recursos de Aprendizagem (CRA). Nesse sentido, o trabalho de integração ocorre mediante colaboração do docente e, em especial, por meio de uma nova concepção de ensino-aprendizagem. De acordo com Gasque (2013), o paradigma

\footnotetext{
${ }^{1}$ http://www.oecd.org/pisa/keyfindings/PISA-2012-results-brazil.pdf.
} 
de integração pedagógica não exclui o paradigma de acesso da informação, mas ambos se complementam, posto que o CRA, para se integrar no processo de aprendizagem, requer, primeiramente, a gestão de informação. Nesse contexto, a $\mathrm{BE}$ deve participar ativamente na promoção das competências leitoras como recurso estratégico, visto que a leitura é um processo cognitivo que possibilita o "aprender a aprender". A ausência do desenvolvimento da competência leitora impede a aprendizagem das estratégias leitoras e, consequentemente, 0 indivíduo não compreende o que lê, tornando-se, assim, mero espectador na sociedade.

Diante disso, cabe questionar, considerando os projetos de leitura, qual é a contribuição da biblioteca escolar nas escolas que obtiveram os melhores desempenhos na avaliação do Exame Nacional do Ensino Médio (Enem).

\subsection{Objetivo Geral}

O objetivo principal da pesquisa é analisar a contribuição da biblioteca escolar nas escolas que obtiveram os melhores desempenhos na avaliação do Enem, considerando especificamente os projetos de leitura.

\subsection{Objetivos específicos}

- Descrever a proposta pedagógica, a estrutura e a concepção pedagógica das seis primeiras escolas do Distrito Federal (DF) no ranking do Enem 2013.

- Descrever a estrutura, os produtos e os serviços oferecidos pela biblioteca escolar das escolas mencionadas.

- Identificar os projetos de leitura e a contribuição da biblioteca escolar para a formação de competências leitoras.

- Identificar a relação entre o docente e o bibliotecário nos projetos de leitura.

\subsection{Justificativa}

Vive-se em uma época em que a tecnologia e a informação transformam processos, serviços e pensamentos de forma acelerada, em que o aprender situa-se no núcleo da sociedade, por isso, pesquisadores como Pozo (2014) e Gasque (2012) denominaram-na de sociedade da aprendizagem. Essa sociedade exige 
certas competências dos cidadãos - denominadas letramento informacional - para que possam avaliar, interpretar, utilizar informação e gerar conhecimento ao longo da vida. Perpassando esse processo, a leitura constitui-se como uma das competências cruciais a ser desenvolvida no referido processo.

As competências podem ser compreendidas como eixos cognitivos de um indivíduo, que, associados às competências disciplinares e áreas do conhecimento, representam o domínio de linguagens, a compreensão de fenômenos, o enfrentamento e resolução de problemas, capacidade de argumentação e elaboração de propostas (INEP ${ }^{2}$, 2014). Para averiguar as competências desenvolvidas no ensino fundamental e médio, o Brasil participa de duas avaliações, uma de caráter nacional, realizada pelo ENEM; e outra internacional (PISA), em que os estudantes não apresentam desempenho satisfatório em relação à escrita e à leitura. A esse respeito, Carvalho (2008) afirma que a escola não forma estudantes críticos e reflexivos, pois o ensino da leitura baseia-se na decodificação, no ensino de uma gramática descontextualizada. Assim, observa-se que um número significativo de estudantes ingressa no Ensino Superior sem 0 devido desenvolvimento de competências leitoras e informacionais.

Neste sentido, a escola é responsável, em grande parte, pela formação de leitores críticos. Isso ocorre porque a sociedade, a família e as bibliotecas escolares e públicas não podem se omitir como colaboradores nesse processo. Na escola, é preciso ressaltar que a BE pode se constituir como recurso importante na formação dos leitores, se houver investimentos na infraestrutura e um trabalho de integração entre docentes e bibliotecários no processo de aprendizagem. Por isso, é necessário mudar de uma concepção de biblioteca escolar como depositária de livros para uma biblioteca dinâmica, atuante como Centro de Recursos de Aprendizagem (CRA).

\footnotetext{
${ }^{2}$ http://portal.inep.gov.br/web/encceja/matriz-de-competencias
} 


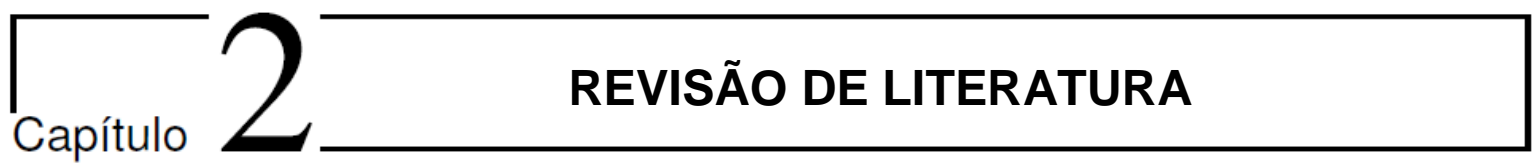

O presente capítulo apresenta a revisão de literatura sobre os conceitos fundamentais da pesquisa, quais sejam, o ensino na Educação Básica, o Enem, a leitura e a Biblioteca Escolar (BE). A revisão da literatura é denominada por muitos autores como "revisão bibliográfica", "estado da arte" ou "estado do conhecimento". De acordo com Caldas (1986) a revisão de literatura pode ser compreendida como o levantamento e registro da informação especializada sobre determinado tema, em período específico de tempo, com o objetivo de apresentar estado da arte sobre o assunto desenvolvido.

\subsection{Educação Básica - Enem}

Neste capítulo, apresentam-se algumas considerações sobre a Educação Básica no Brasil, em especial, sobre os aspectos relacionados ao Ensino Médio e à avaliação do Enem.

A Educação Básica constitui-se de três grandes fases, compondo a base necessária para ascender ao Ensino Superior. A organização do ensino no Brasil é norteada pela constituição de 1988 e pela lei de Diretrizes e a Bases da Educação Nacional (LDB, Lei no 9.394/1996), que são as leis máximas a estruturar a educação brasileira. Cabe ao Ministério da Educação (MEC) atuar a partir da ordenação de tais leis.

Segundo o artigo $21^{\circ}$ da Lei de Diretrizes e Bases da Educação Nacional são dois os níveis escolares:

I - Educação básica, formada pela educação infantil, ensino fundamental e ensino médio;

II - Educação Superior.

De acordo com o referido documento, a educação básica deve assegurar a formação comum, indispensável ao exercício da cidadania aos brasileiros, bem como fornecer-Ihes os meios para as progressões profissional e acadêmica. Observa-se, no Artigo 208, a garantia do acesso gratuito à educação dos quatro aos dezessete anos de idade. 
Após o ensino fundamental, os estudantes ingressam no Ensino Médio, última etapa da Educação Básica. A média de idade dos estudantes que compõem o Ensino Médio é de 14 a 17 anos, com duração mínima de três anos. A LDB define, como finalidades do Ensino Médio, a preparação para a continuidade dos estudos, a preparação básica para o trabalho e o exercício da cidadania.

Os princípios norteadores do ensino médio sustentam-se na Constituição Federal e na LDB (Lei de Diretrizes e Bases da Educação Nacional), que orientam a formação geral voltada para os fundamentos científico-tecnológicos, a qualificação para o trabalho, ambos alicerçados em estéticos, éticos e políticos (DCN, ${ }^{3}$ 2013). Os princípios de ação pedagógica, explicitados no art. 35, da LDB, podem ser observados no quadro 01 , a seguir.

Quadro 1 - Os princípios de ação pedagógica do currículo.

\begin{tabular}{|c|c|}
\hline $\begin{array}{c}\text { I- a consolidação e o } \\
\text { aprofundamento dos conhecimentos } \\
\text { adquiridos no Ensino Fundamental, } \\
\text { possibilitando o prosseguimento de } \\
\text { estudos; }\end{array}$ & $\begin{array}{c}\text { III - o aprimoramento do educando como } \\
\text { pessoa humana, incluindo a formação ética } \\
\text { e o desenvolvimento da autonomia } \\
\text { intelectual e do pensamento crítico; }\end{array}$ \\
$\begin{array}{c}\text { II - a preparação básica para o } \\
\text { trabalho e a cidadania do educando, } \\
\text { para continuar aprendendo, de modo } \\
\text { a ser capaz de se adaptar com } \\
\text { flexibilidade a novas condições de } \\
\text { ocupação ou aperfeiçoamento } \\
\text { posteriores; }\end{array}$ & $\begin{array}{c}\text { IV - a compreensão dos fundamentos } \\
\text { científico-tecnológicos dos processos } \\
\text { produtivos, relacionando a teoria com a } \\
\text { prática, no ensino de cada disciplina. }\end{array}$ \\
\hline
\end{tabular}

Fonte: DCN (2013).

Nos últimos anos, a estrutura curricular passou por constantes mudanças para garantir a qualidade do ensino ofertado e a incorporação de projetos de inclusão social referidos na universalização do Ensino Médio. Como menciona Krawczyk (2009), embora a dicotomia entre trabalho e cidadania seja emblemática, as orientações presentes nas últimas leis e resoluções contemplam a função formativa do estudante.

A Lei de Diretrizes e Bases da Educação Nacional, de 1996, na restruturação de 2012, propõe a reorientação dos currículos, considerando a formação dos

\footnotetext{
${ }^{3}$ Diretrizes Curriculares Nacionais (DCN).
} 
estudantes para a vida, a diversidade cultural e os interesses dos estudantes. Para abranger essas questões, o currículo deve ser flexível.

\subsubsection{Avaliação do Ensino Médio}

As Diretrizes Curriculares Nacionais Gerais para a educação básica indicam três dimensões básicas de avaliação: avaliação da aprendizagem, avaliação institucional interna e externa, e avaliação de redes de educação básica. As duas primeiras são de caráter institucional e devem estar de acordo com o projeto educativo institucional. A avaliação de redes de educação básica é realizada pelo estado, com caráter nacional, e contemplada no Sistema de Avaliação da Educação Básica (SAEB) ${ }^{4}$, desenvolvimento da educação básica (IDEB) ${ }^{5}$ e Exame Nacional do Ensino Médio (Enem). As referidas avaliações são coordenadas pelo Instituto Nacional de Estudos e Pesquisas Educacionais Anísio Teixeira - INEP, encarregado de avaliar o sistema educacional brasileiro a partir de parâmetros de qualidade e equidade.

O Enem foi criado por meio da portaria 438, de maio de 1998, e modificado segundo disposto na Portaria do Ministério da Educação (MEC), nº 807, de 18 de junho de 2010. Tem como principal objetivo avaliar o desempenho do estudante brasileiro ao fim da educação básica, de modo a analisar e contribuir para a melhoria da qualidade desse nível de escolaridade, como se observa pelo artigo um, abaixo.

Art. 10 Instituir o Exame Nacional do Ensino Médio - ENEM como
procedimento de avaliação cujo objetivo é aferir se o participante do
Exame, ao final do Ensino Médio, demonstra domínio dos princípios
científicos e tecnológicos que presidem a produção moderna e
conhecimento das formas contemporâneas de linguagem.
(PORTARIA № 807 , de 18 de junho de 2010).

Com base nos Parâmetros Curriculares Nacionais PCNs, (1997) do ensino médio e fundamental, o Enem teve por princípio avaliar anualmente o aprendizado dos estudantes do ensino médio no Brasil, para auxiliar o MEC na elaboração de

\footnotetext{
${ }^{4}$ (SAEB): informa sobre os resultados de aprendizagem estruturados no campo da Língua Portuguesa e da Matemática.

5 (IDEB): mede a qualidade de cada escola e rede, com base no desempenho do estudante em avaliações do INEP e em taxas de aprovação.
} 
políticas pontuais e estruturais de melhoria do ensino brasileiro. Foi a primeira iniciativa de avaliação geral do sistema de ensino implantado no Brasil.

O primeiro modelo de prova do Enem foi utilizado entre 1998 e 2008, com 63 questões aplicadas em um dia de prova. A partir de 2009, introduziu-se um novo modelo de prova para a avaliação, com a proposta de unificar o vestibular das universidades federais brasileiras. O novo Enem passou, então, a ser realizado em dois dias, com duas provas contendo 180 questões objetivas e uma questão de redação (MEDEIROS, 2002, p.84).

De acordo com o Edital no 01, de 08 de maio de 2013, o exame passou a ser constituído de uma redação em língua portuguesa e de quatro provas objetivas, contendo, cada uma, 45 questões de múltipla escolha. Além do edital normativo, o Enem publicou um guia ( $A$ redação no Enem 2013: guia do participante) com explicações sobre a prova de redação, que consiste na produção de um texto em prosa, do tipo dissertativo-argumentativo, sobre um tema de ordem social, científica, cultural ou política. Os aspectos a serem avaliados relacionam-se às "competências" que devem ter sido desenvolvidas durante os anos de escolaridade. $\mathrm{Na}$ redação, o candidato deve defender uma tese a respeito de um tema específico, apresentando argumentos consistentes, de modo a formar uma unidade textual. O texto deve ser redigido de acordo com a modalidade escrita formal da língua portuguesa.

As provas de Enem, de 2013, foram aplicadas nos dias 26 e 27 de outubro e os rankings oficiais publicados um ano depois, no dia 26 de novembro de 2014 . No primeiro dia, o Enem aplicou as provas de linguagens e códigos, que engloba português e língua estrangeira (inglês ou espanhol), matemática e redação. Nesse dia, a duração máxima do exame é maior: cinco horas e meia. O tema escolhido para a redação 2013 foi "Os efeitos da implantação da Lei Seca no Brasil". A o respeito antes da prova o ENEM publico um caderno intitulado guia de participante para a redação. ${ }^{6}$

As cinco competências avaliadas na prova da redação do Enem são as encontradas, abaixo, no Quadro 02.

\footnotetext{
${ }^{6}$ Maior informação sobre os critérios de avaliação e modelos de provas de redação de anos passados. http://download.inep.gov.br/educacao basica/enem/guia participante/2013/guia participante red acao enem 2013.pdf
} 
Quadro 2- Competências na redação do Enem 2013.

Competência 1 - Demonstrar domínio da modalidade escrita formal da Língua Portuguesa: o texto dissertativo-argumentativo exige alguns critérios, como ter consciência da distinção entre a modalidade escrita e a oral, bem como entre o registro formal e informal. As regras de pontuação e o vocabulário técnico na redação do texto são muito importantes para dar um sentido integral à ideia principal do texto.

Competência 2 - Compreender a proposta de redação e aplicar conceitos das várias áreas de conhecimento para desenvolver o tema, dentro dos limites estruturais do texto dissertativoargumentativo em prosa: o tema constitui o núcleo das ideias sobre as quais a tese do candidato deve se organizar. Em âmbito mais abrangente, o assunto recebe uma delimitação por meio de um tema, ou seja, um assunto pode ser abordado por diferentes temas.

Competência 3 - Selecionar, relacionar, organizar e interpretar informações, fatos, opiniões e argumentos em defesa de um ponto de vista: é preciso que se elabore um texto que apresente, claramente, uma ideia a ser defendida e os argumentos que justifiquem a posição assumida em relação à temática exigida pela proposta de redação.

Competência 4 - Demonstrar conhecimento dos mecanismos linguísticos necessários para a construção da argumentação: os aspectos a serem avaliados nesta competência dizem respeito à estruturação lógica e formal entre as partes da redação. A organização textual exige que as frases e os parágrafos estabeleçam entre si uma relação que garanta a sequência coerente do texto e a interdependência entre as ideias.

Competência 5 - Elaborar proposta de intervenção para o problema abordado, respeitando os direitos humanos: os conhecimentos e ações associados às competências anteriormente mencionadas devem ser mobilizados, utilizados e integrados. Deve-se destacar, também, que essa competência requer o domínio das demais, que estão voltadas para a formação intrínseca do ser, instrumentalizando-o para o exercício da cidadania, que só atingirá sua plenitude com o domínio de todas as competências. A partir da conjetura dessas competências, o cidadão está apto a intervir em sua realidade social.

Fonte: ENEM (2013).

Os resultados do Enem relacionam-se à soma de muitos fatores, como a renda familiar dos candidatos, proposta pedagógica, estrutura curricular, dentre outros aspectos importantes. Nesse sentido, a leitura constituísse em um dos fatores de avanço, visto que melhora o desempenho de estudantes, como se observa pela literatura e, mais especificamente, ${ }^{7}$ por matéria publicada pelo portal do MEC, em 2013.

\subsection{A leitura como Competência no Letramento Informacional}

O surgimento da ciência da informação baseia-se no esforço para resolver os problemas do crescimento exponencial da informação e do conhecimento. A "avalanche" de informações, as inovações tecnológicas e as necessidades cada vez

\footnotetext{
$7 \quad$ http://portal.mec.gov.br/index.php?option=com content\&view=article\&id=19009:interesse-peloslivros-melhora-desempenho-de-alunos-em-sc-\&catid=211.
} 
mais específicas dos indivíduos em relação à informação mostram que a ciência da informação tem evoluído. Considerando tal evolução, Capurro (2003, pp. 9-16) propõe a compreensão da informação delimitada por três paradigmas: físico, cognitivo e social.

O paradigma físico considera a informação como objeto. No que diz respeito ao paradigma cognitivo, o usuário é compreendido como sujeito cognoscente, com modelos mentais do "mundo exterior", a serem transformados no processo informacional. Por sua vez, o paradigma social envolve os dois paradigmas supracitados em busca de um modelo ideal para representar o conhecimento e a recuperação da informação. Não é mais apenas um objeto que é passado ou um processo cognitivo individual, agora, o conhecedor decodifica caracteres num processo interpretativo. Esse processo não se desenvolve somente num ambiente social ou econômico, mas, sim, em um ambiente em que os conhecimentos são transformados de acordo com a realidade vivida. A visão social relaciona-se à construção do conhecimento no contexto social.

Ao considerar os aspectos cognitivos do sujeito e a interação com o ambiente em que vive como espaço de aprendizagem, percebe-se que a sociedade contemporânea traz novos desafios no que concerne à relação com a informação e o conhecimento. Para lidar com esses desafios, o processo de letramento informacional (LI) possibilita o desenvolvimento de competências para buscar e usar a informação para resolução de problemas ou tomada de decisões. Assim, pode ser caracterizado como processo que propicia a aprendizagem ativa, independente, bem como o pensamento reflexivo e o aprender a aprender ao longo da vida (GASQUE, 2013, p.1). A autora, no artigo intitulado "Arcabouço conceitual do letramento informacional" (2010) distingue letramento informacional do termo competência. Competência refere-se às habilidades, ferramentas e saberes prévios ativados ao longo de todo processo de letramento informacional. Igualmente, propõe que "competência seja utilizada como expressão do 'saber fazer', derivada das relações entre o conhecimento que o sujeito detém, a experiência adquirida pela prática e a reflexão sobre a ação" (GASQUE, 2003, p.10).

O conceito de LI emerge na década de 70, em um relatório produzido por Paul Zurkowiski (1974), em que ele demonstrava preocupação com a grande quantidade de informação e a forma de se lidar com o fenômeno informacional. Nas 
décadas posteriores, instituições internacionais como a $A C R L^{8}, A L A^{9}, A S S L^{10}$ apresentaram os padrões de letramento informacional a serem desenvolvidos para lidar com a informação e como bibliotecas e bibliotecários deveriam favorecer o ensino das competências. Em 1998, a American Association of School Librarians (divisão de bibliotecas escolares da ALA), em parceria com a Association for Educational Communications and Technology (AECT), construiu os padrões para a Educação Básica, em que biblioteca escolar tem contribuições importantes no processo de desenvolvimento das competências. O documento apresenta três itens de aprendizagem, nove padrões e vinte e nove indicadores de aprendizagem. No quadro três, a seguir, apresentam-se as competências e padrões de aprendizagem.

Quadro 3 - Letramento informacional para o aprendizado do aluno.

\begin{tabular}{|c|c|}
\hline Padrões & Indicadores \\
\hline $\begin{array}{l}\text { O aluno que tem competência } \\
\text { informacional acessa a } \\
\text { informação de forma eficiente e } \\
\text { efetiva. }\end{array}$ & $\begin{array}{l}\text { 1. Identifica as necessidades de informação. } \\
\text { 2. Que reconhece informações precisas e abrangentes é a } \\
\text { base para a tomada de decisão inteligente. } \\
\text { 3. Questões formuladas baseadas na necessidade de } \\
\text { informação. } \\
\text { 4. Identifica uma variedade de potenciais fontes de informação. } \\
\text { 5. Desenvolve e utiliza estratégias bem-sucedidas para a } \\
\text { localização de informações. }\end{array}$ \\
\hline $\begin{array}{l}\text { O aluno competente } \\
\text { informacionalmente avalia a } \\
\text { informação de forma crítica e } \\
\text { competente. }\end{array}$ & $\begin{array}{l}\text { 1. Determina a precisão, relevância e abrangência. } \\
\text { 2. Distingue fato, ponto de vista e opinião. } \\
\text { 3. Identifica informações imprecisas e enganosas. } \\
\text { 4. Seleciona informação adequada para o problema ou questão } \\
\text { em apreço. }\end{array}$ \\
\hline $\begin{array}{l}\text { O aluno competente } \\
\text { informacionalmente usa a } \\
\text { informação com precisão e } \\
\text { criatividade. }\end{array}$ & $\begin{array}{l}\text { 1. Organiza a informação para aplicação prática, } \\
\text { 2. Integra novas informações ao conhecimento próprio. } \\
\text { 3. Aplica-se a informação no pensamento crítico e resolução de } \\
\text { problemas. } \\
\text { 4. Produz e comunica informações e ideias, em formas } \\
\text { apropriadas. }\end{array}$ \\
\hline
\end{tabular}

Das três competências apresentadas no quadro acima, a primeira é trabalhada, tradicionalmente, pelos bibliotecários, o que não tira a responsabilidade desses profissionais com relação às demais competências.

Os padrões descritos precisam ser trabalhados em uma parceria entre bibliotecários e educadores, reconhecendo a BE como espaço singular de aprendizagem. Consideram-se letrados informacionais os estudantes competentes

\footnotetext{
${ }^{8}$ Association of College and Research Library.

${ }^{9}$ American Association of School Libraries.

${ }^{10}$ Association of College and Research Library.
} 
em buscar e usar a informação, isto é, aqueles que passaram pelo processo de identificar as necessidades de informação, acessar e avaliá-las, bem como comparar, organizar e produzir novas informações. Nesse contexto, a leitura constitui-se em uma competência que perpassa e permite a construção de várias outras.

As competências leitoras requerem gestão de habilidades e estratégias que permitam compreender e interpretar um texto, facilitando a transformação da informação em conhecimento. Para Solé (2012), as competências de leitura são um processo que se desenvolve ao longo da vida. A autora ressalta, ainda, que formar leitores equivale a formar cidadãos, que possam usar a leitura para obtenção de vários objetivos. Esses leitores devem compreender como ocorre o ato ler e como fazê-lo para resolver problemas no cotidiano.

Segundo o documento divulgado pelo Enem (1998), "competências são as modalidades estruturais da inteligência, ou melhor, ações e operações que utilizamos para estabelecer relações com e entre objetos, situações, fenômenos e pessoas que desejamos conhecer". Por sua vez, compreendem-se as competências leitoras como a capacidade de construir significados a partir do que se lê, dos objetivos, do nível e tipos de leitura, segundo Solé (2012). Assim, a competência vincula-se à ideia de saber usar as estratégias de leitura necessárias, no momento adequado.

Moreno (2009) define o leitor competente como aquela pessoa que é capaz de ler, que domina um conjunto de habilidades e estratégias, permitindo-Ihe analisar, avaliar e compreender um texto. Em suma, o leitor competente é quem compreende um texto, reconhecendo a estrutura, o tipo textual, conteúdo e objetivos, considerando os próprios conhecimentos prévios.

A leitura deve ser compreendida como uma das competências informacionais a ser desenvolvida por meio do ensino de estratégias de leituras, saberes prévios ou conhecimento de mundo, que o leitor ativa na hora de interpretar a informação. Um exemplo de projeto para desenvolver competências informacionais com o foco na leitura foi realizado pela Universidade de Brasília, em parceria com a universidade Complutense de Madrid. O projeto de investigação intitulado "Inclusão Digital e Educação Informacional para Saúde" (IDEIAS) objetivou avaliar o processo educativo dos agentes comunitários de saúde (ACS) na transferência da informação 
e desenhar os programas pedagógicos. O modelo de avaliação inclui quatro grandes tópicos - destrezas, conhecimentos, atitudes e impacto social -, divididos em quatro categorias: Inclusão digital, Inclusão informacional, inclusão social, impacto do programa.

Quadro 4 - Competência, leitura da informação e indicadores.

\begin{tabular}{|c|c|c|}
\hline CATEGORIA & COMPETÉNCIA & INDICADORES \\
\hline $\begin{array}{c}\text { Inclusão } \\
\text { informacional }\end{array}$ & Leitura da informação & \\
\hline $\begin{array}{l}\text { Destacam as habilidades } \\
\text { relacionadas com acesso e } \\
\text { uso da informação, assim } \\
\text { como as competências } \\
\text { leitoras (compreensão) } \\
\text { capaz de produzir } \\
\text { conhecimento, comunicá-lo } \\
\text { e avaliá-lo de acordo com as } \\
\text { questões éticas, legais e } \\
\text { econômicas. }\end{array}$ & $\begin{array}{l}\text { Indica as capacidades do sujeito } \\
\text { para compreensão do conteúdo } \\
\text { da informação, com diferentes } \\
\text { finalidades em uma variedade } \\
\text { de contextos, independente do } \\
\text { suporte ou formato. }\end{array}$ & $\begin{array}{lcr}\text { 1. } & \text { Leitura } & \text { efetiva } \\
\text { (compreensiva) } & \text { da } \\
\text { informação. } & \\
\text { 2. Leitura em distintos } & \text { formatos e suportes. } \\
\text { 3. Leitura com distintas } & \text { finalidades }\end{array}$ \\
\hline
\end{tabular}

Fonte. CUEVAS; SIMEÃO (2011).

As competências leitoras permitem que as pessoas acessem e avaliem a informação para a tomada de decisões.

\subsubsection{Leitura - Competência leitora}

O item apresenta alguns conceitos acerca da ação de ler e da prática da leitura, de acordo com as propostas teóricas dos autores Foucamber (1994), Martins (2006) e Solé (2012).

Para Foucamber (1994), a leitura relaciona-se com o ser questionado pelo mundo e por si mesmo, reconhecendo que certas respostas podem ser encontradas na escrita. $O$ acesso à escrita possibilita construir respostas que integram as novas informações ao próprio esquema cognitivo.

Martins (2006) explica que o ato de ler envolve duas fases, a decodificação mecânica de signos linguísticos e o processo de compreensão abrangente, cuja dinâmica engloba componentes sensoriais, emocionais, intelectuais, fisiológicos, neurológicos, bem como culturais, econômicos e políticos. Destaca que ambas são necessárias à leitura, ninguém decodifica sem compreender e compreende sem decodificar. A leitura realiza-se a partir do diálogo do leitor com o objeto lido. 
A leitura é uma competência complexa em que intervêm componentes emocionais, cognitivos e metacognitivos, componentes estratégicos e automáticos, individuais e sociais, cuja apropriação deve-se iniciar desde a educação infantil, uma vez que o domínio requer prática (SOLÉ, 2012).

A partir dos conceitos apresentados, considera-se a leitura como processo de aprendizagem que fornece significados aos dados e às informações. Parte-se da interpretação e relacionamento com os conhecimentos prévios do sujeito, sejam enciclopédicos ou socioculturais, que ajudam a fazer conexões entre o que se sabe e o que o texto apresenta.

Os conhecimentos são adquiridos pelo indivíduo no entorno social, com a leitura de mundo. Como menciona Freire (2003, p.13), a leitura é um "[...] processo que envolve uma compreensão crítica do ato de ler, que não se esgota na decodificação pura da palavra escrita ou da linguagem escrita, mas que antecipa e se alonga na inteligência do mundo". Assim, torna-se importante contextualizar os textos lidos e fazer uso dos conhecimentos prévios, que podem ser categorizados, como mencionam Koch e Elias (2006, p. 18): "conhecimento enciclopédico, conhecimento linguístico e conhecimento interacional, considerados fundamentais para o processo de ler e compreender".

A ilustração 01, abaixo, apresenta um esquema com dois enfoques da leitura, que são a perspectiva tradicional e a atual.

Figura 01 - Enfoques de leitura.

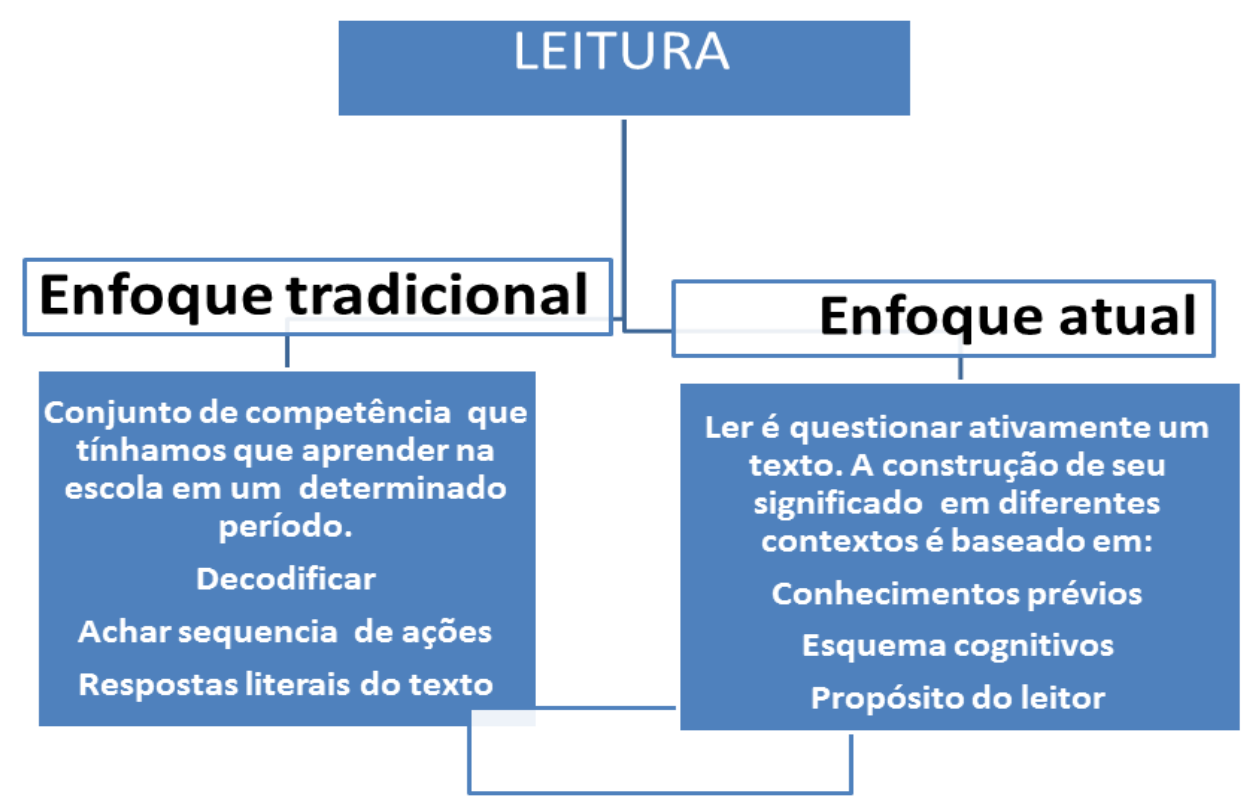

Fonte: Elaboração própria. 
O enfoque atual apresenta-se como ferramenta que transcende a decodificação, permitindo dotar de conhecimentos e competências os leitores que interagem com o texto. A leitura é um exercício completo. Ela deve ser desenvolvida no processo cognitivo para ser aplicada em contextos sociais.

Compreender a leitura como concepção ampla possibilita, como argumenta Solé (2012), uma plena alfabetização. A autora menciona que a leitura não é uma habilidade desenvolvida em um período curto de tempo e aplicada em diversos contextos e situações, como postula a concepção restrita. Ao contrário, a leitura é uma habilidade que se adquire ao longo da vida e que se vincula à experiência de vida. Mais ainda, os objetivos que presidem a leitura e a sua motivação são importantes e auxiliam o leitor a atribuir sentido ao que se lê e, a saber, previamente, para quê serve e quais são os benefícios proporcionados por determinada informação. Por meio dos objetivos delineados ante um texto, é que se podem determinar as estratégias a serem utilizadas, bem como conscientizar o leitor a respeito dos limites na construção de significados, permitindo, assim, o controle da leitura.

É importante que o leitor, especialmente o estudante em formação no processo educacional básico, encontre sentido nas leituras e conheça diversos tipos de estratégias para serem aplicadas em cada contexto de leitura. Sobre isso, Solé (2004, p. 37) afirma que "conhecer variadas estratégias que promovam a compreensão e abordar as tarefas de leitura que exijam utilizá-las é chave para fomentar a leitura compreensiva, crítica e epistêmica".

As referidas estratégias podem ser divididas em três espaços do tempo: "Antes da leitura”, "Durante a leitura”, "Depois da leitura”. O quadro 05, na página a seguir, apresenta as estratégias de leitura nas três fases, de acordo com Solé (2008) e Moreno (2009). Como se pode observar, o quadro mostra os objetivos das estratégias de leitura e exemplos de algumas estratégias a serem utilizadas em cada espaço de tempo. As diferentes estratégias de leituras usadas no processo da compreensão leitora são, comumente, desenvolvidas nas salas de aula por alguns professores, mas a biblioteca escolar, atuante como centro de recurso da aprendizagem (CRA), também pode promover as competências leitoras e as estratégias leitoras por meio de projetos de promoção de leituras liderados por bibliotecários em parceria com os professores, visto que, de acordo com a CERLAC 
(2007), a BE constitui-se como o melhor lugar para promover as competências informacionais e leitoras.

Quadro 5 - Estratégias de leitura (Texto adaptado para o formato de figura e tradução nossa do espanhol)

\begin{tabular}{|c|c|c|}
\hline & Solé (2008) & Moreno (2009) \\
\hline ANTES & $\begin{array}{l}\text { Estratégias que } \\
\text { permitem dotar-se de } \\
\text { objetivos de leitura e } \\
\text { atualizar os } \\
\text { conhecimentos prévios } \\
\text { relevantes. }\end{array}$ & $\begin{array}{l}\text { - } \quad \text { Fazer inferências com o título: o que disse? } \\
\text { - } \quad \text { que sugere? } \\
\text { - } \quad \text { Felacionar o título com o possível conteúdo. } \\
\text { - } \quad \text { Ativar conhecimentos prévios } \\
\text { - } \quad \text { Ensinar o vocabulário necessário } \\
\text { - } \quad \text { Consisar como ler. Sublinhar. } \\
\quad \text { diagramas. a estrutura de textos mediante }\end{array}$ \\
\hline DURANTE & $\begin{array}{l}\text { Fazer inferências de } \\
\text { diferentes tipos, revisar } \\
\text { e comprovar a própria } \\
\text { compreensão durante o } \\
\text { ato de ler e tomar } \\
\text { decisões certeiras ante } \\
\text { os erros e as falhas na } \\
\text { compreensão. }\end{array}$ & $\begin{array}{l}\text { - } \quad \text { Reler mediante perguntas explícitas e } \\
\text { inferenciais. } \\
\text { - } \quad \text { Revisar o conteúdo. } \\
\text { - } \quad \text { Aodificar ou confirmar hipóteses. } \\
\text { - } \quad \text { Avaliar o conteúdo e a forma do texto. }\end{array}$ \\
\hline DEPOIS & $\begin{array}{l}\text { Recapitular o conteúdo, } \\
\text { resumi-lo e ampliar o } \\
\text { conhecimento mediante } \\
\text { a leitura realizada. }\end{array}$ & $\begin{array}{ll} & \text { Fazer perguntas literais } \\
\text { - } & \text { Gerar inferências lógicas } \\
\text { - } & \text { Resumir e sintetizar } \\
\text { Generalizar o conhecimento }\end{array}$ \\
\hline
\end{tabular}

Fonte: SOLE (2004); MORENO (2009).

\subsection{Biblioteca Escolar - Centro de Recursos de Aprendizagem}

O conceito de BE sofreu alterações ao longo do tempo, tendo, consequentemente, alterado as funções e o papel na Escola. Compreendida durante séculos como depositária de livros, precisa assumir a missão essencial de apoiar alunos e professores no desenvolvimento de competências cognitivas. Isso significa que deve ser identificada como Centro de Recursos de Aprendizagem (CRA) e integrada à proposta pedagógica da escola.

O quadro 06 apresenta as diferenças entre os paradigmas da biblioteca escolar tradicional daquela atuante como Centro de Recursos de Aprendizagem. 
Quadro 6 - Paradigmas da biblioteca escolar.

Biblioteca escolar tradicional

BE

- Paradigma da preservação.

- Foco no acesso à informação.

- Centrado na transmissão de conhecimento.

- Depositária de livros.

- Animação de leitura

\section{Centro de recursos de aprendizagem}

\section{CRA}

- Paradigma da integração pedagógica

- Espaços multiusos

- Favorece a socialização.

- Centra-se no letramento informacional

- Propicia acesso aos diferentes pontos de vistas de um conteúdo.

- Instrumento de desenvolvimento do currículo

- Fomenta a leitura e a pesquisa cientifica.

- Caráter pedagógico/cultural

- Apoia a formação continuada

- Estrutura adequada, Layout funcional

- Prontidão para o uso de TIC's

Fonte: Adaptado de Gasque (2012).

Do lado esquerdo do quadro, apresentam-se as características da BE tradicional e, do lado direito, as características do CRA. O ponto principal é a compreensão do CRA vinculado à proposta pedagógica da escola. É importante perceber que, segundo Gasque (2013), o paradigma de integração pedagógica não exclui o paradigma de acesso na informação, posto que o CRA, para integrar-se, requer a gestão da informação.

A definição de Conde (2010, p. 31) resume as caraterísticas mencionadas do CRA.

As bibliotecas escolares são hoje encaradas como espaços criativos de trabalho e de produção de conhecimento, onde as competências tecnológicas, digitais e de informação podem ser aprendidas e exercitadas na realização de novos objetos e recursos de aprendizagem.

Essa nova perspectiva foi recomenda pela Organização dos Estados Americanos OEA (1985), na década de 1980. A instituição destaca uma nova concepção de bibliotecas escolares e ressalta a importância da integração das bibliotecas escolares ao sistema educacional, bem como a importância da formação do bibliotecário escolar e o desenvolvimento de políticas públicas de leitura. Ressalta, ainda, que a BE tem que estar integrada ao projeto educativo institucional, 
deve contribuir em atividades em sala de aula e, ao mesmo tempo, manter a liderança na promoção de serviços e promoção de leitura.

A OEA (1985) conceitua a biblioteca escolar como um centro de aprendizagem, com participação direta em todos os aspectos do programa de educação. Nos espaços do CRA, educadores, estudantes e usuários em geral, podem redescobrir e ampliar os conhecimentos, desenvolver pesquisas e novas aptidões para a leitura, assim como interagir com todos os meios de comunicação, com o objetivo de assegurar a aprendizagem.

Em 1999, realizou-se, em Santiago do Chile, o Seminário Internacional de Bibliotecas Escolares, com a participação de 24 países latino-americanos e europeus. O seminário mostrou, no conjunto, as mudanças de paradigmas na educação dos anos 90 e deu um novo passo na conceituação de biblioteca escolar, ao orientar a incorporação e o uso de materiais diversos, como as multimídias, nos centros de recursos de aprendizagem e ao considerar a função da biblioteca escolar para ensinar as habilidades informacionais. Nas reformas educativas realizadas nessa década, os países apostaram na nova configuração das bibliotecas escolares para promover aos estudantes e à comunidade educativa as competências de pesquisa, avaliação, interpretação e uso da informação (CERLALC ${ }^{11}$, 2007).

A publicação do CERLALC (2007) sobre as bibliotecas escolares da lberoAmérica apresenta propostas para políticas públicas sobre a importância da integração da biblioteca escolar ao sistema educativo e na promoção da leitura, de acordo com os níveis das propostas curriculares. Menciona ainda, cinco critérios que são importantes para a integração das BE ao processo educativo: inclusão nas políticas educativas; projeto educativo institucional; estar consideradas no currículo; formar leitores; e ter participação no manejo das fontes informativas. Os dois primeiros critérios têm relação com a sensibilidade, o pensamento coletivo e as decisões políticas, e os três últimos, com o processo de letramento.

Finalmente, destaca-se que a concepção de Centro de Recursos de Aprendizagem abrange o paradigma da preservação do conhecimento, paradigma do acesso à informação e o paradigma da integração pedagógica. Gasque (2013) argumenta que a organização e os serviços do CRA devem ser concebidos com o

\footnotetext{
${ }^{11}$ Centro Regional para o Fomento do Livro na América Latina, Caribe, Espanha e Portugal, o qual tem como missão apoiar os governos na formulação de políticas e programas orientados à consolidação de sociedades leitoras.
} 
objetivo de contribuir no desenvolvimento de competências básicas dos estudantes, em que o acesso à informação e uso dela são os passos prévios para a produção de conhecimentos.

A concepção de biblioteca escolar tradicional de organizar, armazenar e preservar informação deve mudar para uma concepção de integração, que abrange, dentre outros, o trabalho docente na formação de competências que os estudantes precisam desenvolver. Isso requer sair de algo estático para um paradigma mais dinâmico. Como menciona Cuevas (2007, p. 3), "a sociedade do conhecimento procura uma reorientação no modelo da biblioteca escolar que a transforme em centro de recursos para a aprendizagem e em componente essencial da educação".

\subsubsection{Promoção da leitura no CRA}

O Manifesto IFLA/UNESCO sobre Biblioteca Escolar (2000, pp. 1-4) situa a biblioteca escolar no paradigma de integração pedagógica, com foco nos processos de aprendizagem. A BE dota os estudantes com os instrumentos que Ihes permitem aprender ao longo da vida, desenvolver a imaginação, formando cidadãos responsáveis. O Manifesto destaca a participação da biblioteca escolar dentro e fora da comunidade escolar no desenvolvimento do pensamento crítico mediante a leitura. A biblioteca escolar tem a missão de se integrar ao processo educativo e de promover a leitura e o uso de recursos informativos. Assim, assinala os seguintes objetivos da BE:

- Apoiar o cumprimento dos objetivos do currículo.

- Promover a leitura.

- Fortalecer capacidades em letramento informacional.

- Promover a cultura.

- Promover o acesso à informação respeitando os direitos autorais.

- Expandir os serviços da BE na comunidade.

Os objetivos e as diretrizes do manifesto realçam a configuração da biblioteca escolar e a leitura como meio de inserção social, de acesso à informação, ao conhecimento e aos múltiplos saberes. As políticas educativas de respaldo ao livro, à leitura e à biblioteca escolar apresentam possibilidades de mudança de 
paradigmas nas bibliotecas, no que concerne especificamente à implantação de projetos de estímulo à leitura.

Nessa perspectiva, os profissionais atuantes nas BEs precisam de conhecimentos teóricos e práticos para construir propostas tanto no nível institucional quanto nacional. Cuevas (2007) argumenta que os profissionais devem agir em prol do desenvolvimento de competências de leitura, uma vez que, obtidas tais competências, o hábito de ler pode se tornar parte dos interesses pessoais de cada um. Ou seja, a condição necessária para ser leitor é, simplesmente, saber ler.

O bibliotecário tem uma dupla missão: promover a leitura e, ao mesmo tempo, ser aliado do professor em relação às competências de leitura, considerando nos projetos de leituras, a promoção de estratégias de compreensão leitora. Isso porque se costuma falar da importância da biblioteca ao se abordar o tema da leitura, mas a biblioteca, é necessário ressaltar, não funciona sozinha. É o profissional da informação quem a ancora com os conhecimentos e experiências, visto que a biblioteca é uma estrutura física e são os bibliotecários que dão vida ao espaço. São eles que podem fazer dela um lugar muito amigável (ALFARO, 2009).

A presença de políticas em prol do livro, da leitura e da biblioteca escolar, no Brasil, aponta para a formação e capacitação dos profissionais que trabalham com essas temáticas, como professores, bibliotecários, animadores culturais, etc. Santos (2009) e Naranjo (2005) afirmam que a prioridade máxima para se melhorar os índices de leitura é formar pessoas capacitadas para serem mediadores. Para tanto, a formação de bibliotecário como mediador, deve passar pela aquisição da compreensão dos processos de leitura, dos tipos de leitura, das estratégias de leitura, dos aspectos políticos e culturas que influenciarão na formação de leitores.

É preciso questionar se os bibliotecários estão preparados para responder aos compromissos de liderança nos projetos de leitura, nas instituições educativas, e se conhecem as políticas públicas nacionais. A Lei no 12.244, por exemplo, menciona que as escolas públicas e privadas devem ter bibliotecas administradas por profissionais com bacharelado em Biblioteconomia. Tanto a sociedade civil quanto as instituições estatais de formação especializada têm que considerar a formação dos mediadores de leitura. 
As bibliotecas escolares desenvolvem atividades relacionadas à leitura que giram em torno de duas concepções, quais sejam, a "animação da leitura" e a "promoção da leitura". Muitas vezes, elas são utilizadas indistintamente, não permitindo a diferenciação, e generalizando todas as atividades referidas ao tema.

Por isso, Cuevas (2007) e Naranjo, (2005) diferenciam os dois termos. Animação da leitura refere-se à atividade que motiva os leitores, que possibilita a recreação mediante leitura de textos selecionados. Por sua vez, a promoção da leitura transcende a animação do livro e o uso da biblioteca, centrando-se no ensino de estratégias de leitura e fazendo uso da leitura dialogada para fortalecer as competências leitoras nos estudantes. Cuevas (2007, p. 55) explica que

a promoção da leitura é um marco geral estratégico que articula globalmente ações estruturadas e sistematizadas a uns objetivos integrados em um plano de institucional para fomentar a leitura, centrando-se na formação leitora, não na promoção do livro.

Vale destacar que, nos projetos de leitura ou atividades de leitura, é necessário considerar as atividades de promoção das competências leitoras. Animação é a motivação para um momento de lazer, enquanto a promoção é experimentar um processo de aprendizagem.

Existem experiências de animação de leitura interessantes, como se observa na dissertação intitulada "O papel da Biblioteca Escolar na motivação e promoção da leitura: implementação do projeto 'Vamos dar Vida aos LIVROS!", de Morgado (2012). Esse projeto objetivou destacar a importância da leitura no desenvolvimento do indivíduo e da sociedade; considerar o papel da BE na motivação e na criação de hábitos de leitura dos alunos; e motivar o gosto pela leitura. Para isso, programou-se o projeto "Vamos dar Vida aos LIVROS!", que consistiu na realização de atividades diversificadas, com o envolvimento dos professores, bibliotecários e pais de família. O projeto foi realizado com um grupo de controle e, posteriormente, comparado com outro grupo com caraterísticas similares. A autora reafirma a importância da participação da BE na promoção da leitura.

Acreditamos fervorosamente que a BE tem um papel fundamental na motivação, no desenvolvimento de competências de leitura e na criação de hábitos regulares desta importante atividade. Assim, a BE, [...] está consciente que urge implementar projetos diversificados, sistemáticos e consistentes de animação e promoção da leitura, em 
articulação com os docentes, com a família, com a BM e com a comunidade em geral (MORGADO, 2012, p.111).

A autora conclui que cabe à $\mathrm{BE}$ papel determinante na criação de hábitos de leitura, isso porque os resultados mostram que houve aumento no estímulo, nos hábitos e na compreensão leitora dos estudantes.

Outra experiência que apresenta a proposta de estimular a leitura no letramento informacional foi apresentada por Cuevas (2008), a partir do projeto denominado "ALFINLEE". Tal projeto baseia-se em três categorias: a primeira, a alfabetização, a informação e as leituras; a segunda relaciona-se à leitura e à aprendizagem; e, por fim, a terceira refere-se ao aperfeiçoamento pessoal e à leitura. A autora conclui que o letramento informacional, orientado a favorecer as competências leitoras, constitui-se como a chave para o desenvolvimento contínuo dos estudantes na escola, em que a BE, como CRA, apresenta-se como mediadora da cultura e aprendizagem e o recurso mais adequado para desenvolver propostas integradoras entre o bibliotecário e o professor no planejamento de atividades curriculares.

A partir da bibliografia consultada para essa pesquisa, é possível afirmar a importância do planejamento dos projetos de leitura. Considerando essa questão, apresenta-se, na ilustração 02 , um esquema em que se representa o processo e os passos que se devem considerar no planejamento de um projeto de leitura na BE.

Figura 2 - Processo de projeto de leitura.

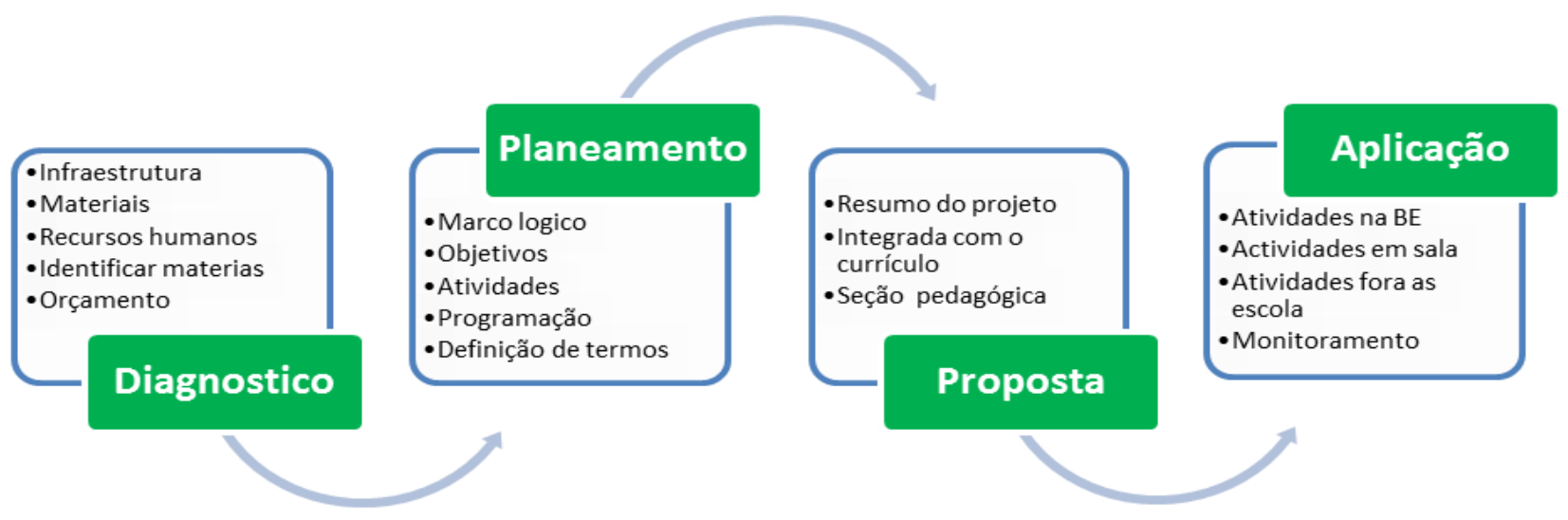

Fonte: Elaboração própria. 
Como se observa no esquema, os projetos de leitura na BE devem abranger quatro fases:

Diagnóstico: conhecer a infraestrutura, o tipo de coleção, os serviços, os projetos, os recursos humanos, financeiros, e as parcerias. Além disso, é importante conhecer o paradigma subjacente à concepção da biblioteca.

Planejamento. Conhecer os resultados do diagnóstico permite definir objetivos, atividades, indicadores. Recomenda-se utilizar a matriz de consistência do marco lógico, ferramenta utilizada para a gestão, formulação, execução, monitoração e avaliação de projetos e programas. Esta ferramenta pode ser adaptada na elaboração projetos de leitura desenvolvidos no CRA.

Proposta de intervenção. Definir a proposta e a metodologia em função do cronograma, considerando as horas pedagógicas recomendadas para trabalhar na escola. A proposta de intervenção também deve considerar a sessão pedagógica (motivação, fundamentação, participação, avaliação, reflexão) e a articulação com o currículo.

Aplicação. Interagir com os alunos e professores no desenvolvimento das atividades em sala de aula ou na biblioteca, considerando que todas as atividades devem gerar um informe.

$\mathrm{Na}$ base da elaboração de um projeto de leitura, requer considerar os pontos mencionados e os temas, para serem aplicados, precisam relacionar-se com a promoção das competências leitoras, como o uso de estratégias, os tipos de textos, com a finalidade de promover o pensamento crítico. Um planejamento adequado permite ao bibliotecário promover a configuração da BE e contribuir de maneira eficiente para melhoria das competências leitoras nos estudantes. 


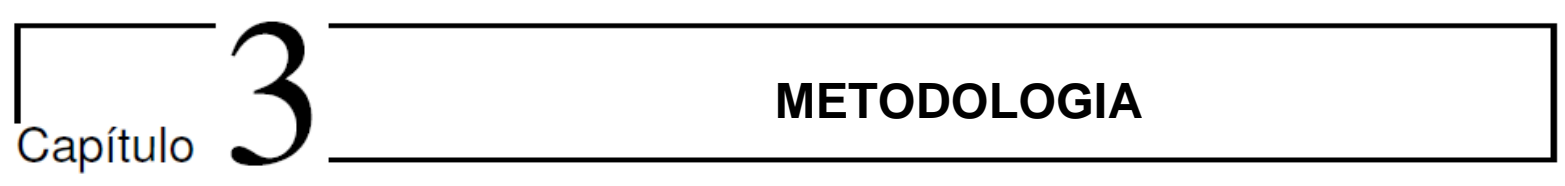

A metodologia abrange o estudo dos métodos, possibilitando a seleção daqueles mais adequados à resolução de um problema. O conceito de método relaciona-se à ordem em que os diferentes passos, utilizados para atingir determinado fim, são estruturados. Ao se compreender que a pesquisa científica visa à obtenção da verdade - mesmo provisória -, o método é utilizado para facilitar a apresentação de problemas e a comprovação de hipóteses. As hipóteses são possíveis respostas antecipadas, que vinculam a observação e a teoria científica com o objetivo de entender a realidade. Isso permite detectar erros e auxiliar na construção do conhecimento válido (CUNHA, 2008; LAKATOS, 2011). A metodologia da pesquisa foi composta pelo referencial teórico, descrição da pesquisa, instrumento de coleta de dados e caracterização da amostra.

\subsection{Referencia Teórico}

O referencial teórico pode ser compreendido como uma "lente" para interpretar o problema da pesquisa, ou seja, "uma versão do mundo que permite revisão, avaliação e reconstruções contínuas". No referencial teórico, o pesquisador descreve os conceitos principais envolvidos na pesquisa, bem como as relações entre os conceitos, devidamente amparados pela linha de pesquisa e teorias adotadas (GASQUE, 2008, p. 108).

O referencial teórico da pesquisa fundamenta-se nas relações entre os conceitos de Bibliotecas atuantes como CRA, leitura, competências leitoras e competência informacional. Os conceitos são descritos a seguir:

Biblioteca escolar: na presente pesquisa, considera-se a concepção de Centro de Recursos de Aprendizagem (CRA), termo usado no documento "Modelo Flexível para um Sistema Nacional de Bibliotecas Escolares" (ORGANIZAÇÃO DOS ESTADOS AMERICANOS - OEA, 1985, p. 22) e por Gasque (2013). Nessa perspectiva, as bibliotecas devem atuar como Centro de Recursos de Aprendizagem 
de forma integrada ao processo pedagógico da escola, isto é, em consonância com o currículo e a concepção pedagógica da escola.

No documento "Por las bibliotecas escolares de Ibero América" (CERLAC; UNESCO, 2007, pp. 30-34), são apresentados elementos de integração na prática da BE.

- A Biblioteca Escolar e a política educativa: a concepção do espaço deve ser pensada em consonância com as políticas educativas, modelos educativos e pedagógicos, visto que ela deve contribuir para alcançar as metas educativas nacionais.

- Biblioteca Escolar e o projeto educativo institucional: a BE participa ativamente no planejamento dos projetos e planos da instituição. Nesse sentido, os conteúdos de ensino sobre LI precisam estar inseridos, no projeto, de forma transversal.

- Biblioteca Escolar e currículo: as BEs precisam participar ativamente das atividades interdisciplinares, visto que devem construir a missão em parceria com os docentes e com a comunidade educativa, conservando a autonomia na promoção das práticas sociais e culturais da leitura e da escrita. - $\quad$ Biblioteca Escolar e formação de leitores: a BE deve atuar como ambiente de promoção e formação de leitores, propiciando acesso ao livro e a formas de leitura mais dinâmicas.

- Biblioteca Escolar e formação para buscar e usar as fontes informativas: as BEs são espaços de aprendizagem e de inclusão dos estudantes no mundo informacional. Nesse sentido, o bibliotecário precisa atuar como parceiro dos professores das diferentes áreas curriculares.

A biblioteca escolar, como CRA, engloba os conceitos acima mencionados pela CERLAC (2007), atuando como espaço de interação no processo da aprendizagem e no trabalho colaborativo entre o docente e o bibliotecário, na promoção das competências leitoras e competências informacionais da comunidade educativa. 
Leitura: considera-se a leitura como processo de aprendizagem que fornece significados aos dados e às informações. Parte-se da interpretação e do relacionamento com os conhecimentos prévios do sujeito, os quais ajudam a fazer conexões entre o que se sabe e o que o texto apresenta. Nessa pesquisa, adota-se o conceito de leitura na prática, como competência leitora, que auxilia o processo de aprendizagem que permite interpretar, avaliar um texto, transformando a informação em conhecimento para a tomada de decisões.

Competência leitora: conhecimentos e estratégias adquiridos pelos estudantes no período escolar, durante o processo de aprendizagem da leitura, postos em prática diante de determinado texto. Essas competências leitoras permitem analisar, comparar, interpretar e compreender a informação.

Competência informacional: refere-se à capacidade do aprendiz de mobilizar o próprio conhecimento que o ajudará a agir em determinada situação. Ao longo do processo de letramento informacional, os aprendizes desenvolvem competências para identificar a necessidade de informação, avaliá-la, buscá-la e usá-la eficaz e eficientemente, considerando os aspectos éticos, legais e econômicos (GASQUE, 2013).

Nessa pesquisa, parte-se do pressuposto que o desenvolvimento da competência leitora no processo de $\mathrm{LI}$, realizada nas BEs, em parceria com os docentes, influencia positivamente na aprendizagem dos estudantes, como se aponta na ilustração 03. Nessa concepção, a biblioteca escolar, portanto, não é só uma estrutura física, mas local que agrega as competências do bibliotecário para participar ativamente da promoção de atividades de estímulo à leitura, por meio do trabalho compartilhado com os docentes e com a comunidade escolar.

Figura 3 - Referencial teórico

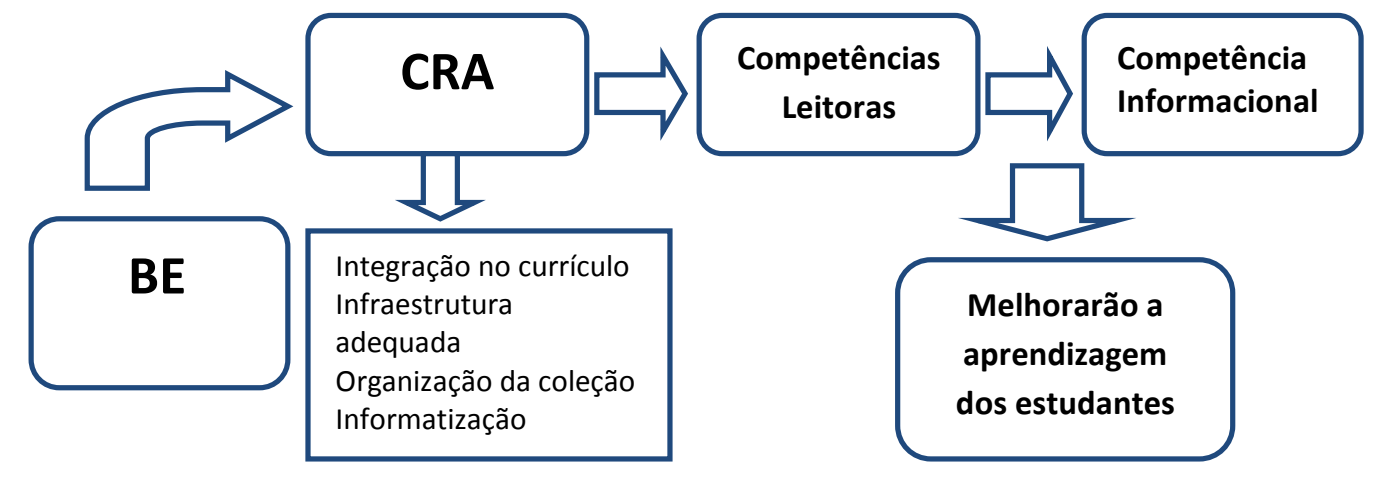

Fonte: Elaboração própria. 
O esquema encontrado na ilustração 03 busca mostrar que a concepção da $\mathrm{BE}$ escolar transcende a ideia de depositária de livros para se converter em um Centro de Recursos de Aprendizagem com objetivo de melhorar a aprendizagem dos estudantes. Isso ocorre a partir da promoção das competências leitoras, que, finalmente, convertem-se em ferramenta importante no processo de letramento informacional, posto que, com o domínio dessas competências, pode-se analisar e interpretar a informação, completando o círculo de competência informacional de acesso e uso da informação.

\subsection{Descrição da Pesquisa}

A presente pesquisa é de natureza qualitativa e quantitativa, de nível descritivo-explicativo. Pode ser caracterizada dessa forma por buscar identificar a natureza profunda das realidades, o sistema de relações conceituais e a estrutura dinâmica do contexto. Para isso, realizaram-se registros narrativos dos fenômenos em torno da biblioteca escolar e da leitura, explicados no decorrer da pesquisa. Gil (2010) afirma que uma pesquisa explicativa pode e deve funcionar como a continuação de outra pesquisa de cunho descritivo, posto que, para fazer a identificação dos fatores que determinam um fenômeno, é exigido que este esteja suficientemente descrito e detalhado.

\subsubsection{Instrumento de coleta de dados}

A coleta de dados dividiu-se em três partes. Na primeira fase, realizou-se a pesquisa documental da escola. A finalidade foi colocar o pesquisador em contato direto com o que foi escrito sobre o assunto escolhido (MARCONI; LAKATOS, 1999) para conhecer o projeto e a estrutura pedagógica das seis primeiras escolas do ranking do Enem 2013 do DF. Na segunda parte, ocorreu a avaliação da BE, por meio de um formulário, de acordo com os padrões propostos pelo Conselho Federal de Biblioteconomia (CFB) e pelo Grupo de Estudos em Biblioteca Escolar (GEBE) da Escola de Ciência da Informação da Universidade Federal de Minas Gerais (UFMG). A terceira parte constou da aplicação de questionários aos docentes que trabalham em projetos de leitura. 
Abaixo, seguem os instrumentos de coleta de dados que permitiram responder melhor às questões da presente pesquisa.

Quadro 7 - instrumentos de coleta de dados.

\begin{tabular}{|c|c|}
\hline Objetivos específicos & Instrumento de coleta de dados \\
\hline $\begin{array}{l}\text { Descrever a estrutura e a concepção } \\
\text { pedagógica das cinco primeiras escolas do } \\
\text { DF no ranking do Enem } 2013 \text {. }\end{array}$ & Análise documental \\
\hline $\begin{array}{l}\text { Descrever a estrutura, os produtos e } \\
\text { serviços oferecidos pela biblioteca escolar } \\
\text { das escolas mencionadas. }\end{array}$ & $\begin{array}{l}\text { Formulário dos padrões da GEBE- } \\
\text { UFMG }\end{array}$ \\
\hline $\begin{array}{l}\text { Identificar os projetos de leitura e a } \\
\text { contribuição da biblioteca escolar para } \\
\text { formação de competências leitoras. }\end{array}$ & Questionário aos docentes \\
\hline $\begin{array}{l}\text { Identificar a relação entre o docente e o } \\
\text { bibliotecário nos projetos de leitura. }\end{array}$ & Questionário aos docentes \\
\hline
\end{tabular}

Fonte: Elaboração própria.

\subsubsection{Análise documental}

A análise documental, de acordo com Pimentel (2001), é uma técnica que utiliza documentos como subsídios para as pesquisas. O objetivo é extrair deles informações que serão organizadas e interpretadas conforme os objetivos da investigação proposta.

No caso dessa pesquisa, foram realizadas análise de documentos dos sites dos colégios, da publicidade impressa e documentos divulgados pelos colégios. Por esses materiais, foram identificadas informações acerca do projeto pedagógico e dos projetos extracurriculares.

\subsubsection{Formulário dos padrões da GEBE-UFMG}

Formulários são, de acordo com Gil (2002), instrumentos de pesquisa, que se situam entre o questionário e a entrevista, sendo indicados para pesquisas de opinião pública e de mercado. Os formulários propostos pela GEBE/UFMG são 
compostos de 89 questões com o objetivo de coletar dados sobre a estrutura, produtos e serviços, recursos humanos, dentre outros aspectos.

A aplicação dos formulários ocorreu no período de outubro a novembro de 2014, nos mesmos dias em que os professores responderam os questionários. O processo demorou em média 3 horas e foi acompanhado pela própria pesquisadora. Em seguida, a pesquisadora realizou duas perguntas relacionadas à questão da leitura:

1) Desenvolvem atividades que promovem as competências leitoras?

2) Como é o trabalho de integração com os docentes?

A aplicação das perguntas demorou em média 20 minutos. As respostas foram anotadas por tópicos em um bloco de notas e, posteriormente, tabuladas.

As BEs foram avaliadas de acordo com os padrões propostos pelo CFB e o GEBE. Nessa proposta, os padrões são divididos em duas partes, que são: os indicadores de gestão, que representam o nível básico em que uma biblioteca deve funcionar e apontam o nível exemplar, isto é, um horizonte a ser alcançado; e os indicadores de seguimento, que ampliam os indicadores acima mencionados, permitindo que a escola analise e avalie, detalhadamente, a biblioteca, traçando metas e prazos para o aperfeiçoamento. Os padrões de avaliação estão divididos em dois itens: indicadores relativos à estrutura física e ao planejamento da BE. Segundo os padrões do GEBE, consideraram-se os seguintes indicadores:

Quadro 08 - Padrões da avaliação da BE segundo Grupo de Estudos em Biblioteca Escolar (GEBE) da UFMG.

\begin{tabular}{|c|c|c|}
\hline $\begin{array}{c}\text { Padrões da } \\
\text { avaliação } \\
\text { da BE } \\
\text { segundo o } \\
\text { GEBE }\end{array}$ & NÍVEL BÁSICO & NIVEL EXEMPLAR \\
\hline $\begin{array}{c}\text { Padrões da } \\
\text { avaliação } \\
\text { da BE } \\
\text { segundo o } \\
\text { GEBE }\end{array}$ & $\begin{array}{l}\text { - De } 50 \mathrm{~m}^{2} \text { a } 100 \mathrm{~m}^{2} \text {; } \\
\text { - Assentos suficientes para } \\
\text { acomodar simultaneamente } \\
\text { uma classe inteira, além de } \\
\text { usuários avulsos; } \\
\text { - Um balcão de atendimento, } \\
\text { uma mesa, uma cadeira e } \\
\text { um computador com acesso } \\
\text { à internet, para uso exclusivo } \\
\text { do(s) funcionário(s). }\end{array}$ & $\begin{array}{l}\text { - Acima de } 300 \mathrm{~m}^{2} \text {; } \\
\text { - Assentos suficientes para acomodar } \\
\text { simultaneamente uma classe inteira, } \\
\text { usuários avulsos e grupos de } \\
\text { alunos. } \\
\text { - Um balcão de atendimento e } \\
\text { ambiente específico para atividades } \\
\text { técnicas, com uma mesa, uma } \\
\text { cadeira e um computador com } \\
\text { acesso à internet, para uso exclusivo } \\
\text { de cada um dos funcionários. }\end{array}$ \\
\hline
\end{tabular}




\begin{tabular}{|c|c|c|}
\hline \multirow{2}{*}{$\begin{array}{l}\text { Padrões da } \\
\text { avaliação } \\
\text { da BE } \\
\text { segundo o } \\
\text { GEBE }\end{array}$} & $\begin{array}{l}\text { - A partir de um título por } \\
\text { aluno. }\end{array}$ & $\begin{array}{l}\text { - A partir de quatro títulos por aluno, } \\
\text { não sendo necessário mais do que } \\
\text { cinco exemplares de cada título. }\end{array}$ \\
\hline & \multicolumn{2}{|c|}{$\begin{array}{l}\text { Além de livros, a biblioteca escolar deve contar com revistas e outros materiais não } \\
\text { impressos, tais como: documentos sonoros, visuais e digitais. }\end{array}$} \\
\hline $\begin{array}{l}\text { Padrões da } \\
\text { avaliação } \\
\text { da BE } \\
\text { segundo o } \\
\text { GEBE }\end{array}$ & $\begin{array}{l}\text { - Pelo menos um computador } \\
\text { ligado à internet para uso } \\
\text { exclusivo de professores e } \\
\text { alunos em atividades de } \\
\text { ensino/ aprendizagem. }\end{array}$ & $\begin{array}{l}\text { - Computadores ligados à internet } \\
\text { para uso exclusivo de professores e } \\
\text { alunos em atividades de ensino/ } \\
\text { aprendizagem, em número suficiente } \\
\text { para uma classe inteira. }\end{array}$ \\
\hline $\begin{array}{l}\text { Padrões da } \\
\text { avaliação } \\
\text { da BE } \\
\text { segundo o } \\
\text { GEBE }\end{array}$ & $\begin{array}{l}\text { - O catálogo da biblioteca } \\
\text { inclui pelo menos os livros do } \\
\text { acervo, permitindo } \\
\text { recuperação por autor, título } \\
\text { e assunto. }\end{array}$ & $\begin{array}{l}\text { - O catálogo da biblioteca é } \\
\text { informatizado e possibilita o acesso } \\
\text { remoto a todos os itens do acervo; } \\
\text { permite - além de recuperação por } \\
\text { autor, título e assunto - recuperação } \\
\text { por outros pontos de acesso. }\end{array}$ \\
\hline $\begin{array}{l}\text { Padrões da } \\
\text { avaliação } \\
\text { da BE } \\
\text { segundo o } \\
\text { GEBE }\end{array}$ & 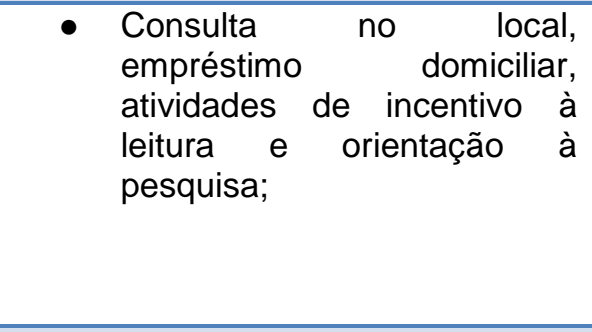 & $\begin{array}{l}\text { - Consulta no local, empréstimo } \\
\text { domiciliar, atividades de incentivo à } \\
\text { leitura e orientação à pesquisa, além } \\
\text { de serviço de divulgação de novas } \\
\text { aquisições, exposições e serviços } \\
\text { específicos para os professores, tais } \\
\text { como levantamento bibliográfico e } \\
\text { boletim de alerta. }\end{array}$ \\
\hline $\begin{array}{c}\text { Padrões da } \\
\text { avaliação } \\
\text { da BE } \\
\text { segundo o } \\
\text { GEBE }\end{array}$ & $\begin{array}{l}\text { Um bibliotecário supervisor, } \\
\text { responsável por um grupo de } \\
\text { bibliotecas (nos casos em } \\
\text { que a biblioteca faz parte de } \\
\text { um sistema/rede que reúne } \\
\text { várias bibliotecas), além de } \\
\text { pessoal auxiliar em cada } \\
\text { uma das bibliotecas, em } \\
\text { cada turno. }\end{array}$ & $\begin{array}{l}\text { - Um bibliotecário responsável pela } \\
\text { biblioteca e pessoal auxiliar em cada } \\
\text { turno, de acordo com o número de } \\
\text { alunos da escola. }\end{array}$ \\
\hline
\end{tabular}

Fonte: adaptado do Grupo de Estudos em Biblioteca Escolar. UFMG (2010).

\subsubsection{Questionário}

Segundo Gil (2010, p. 120), o questionário pode ser definido como uma técnica de investigação composta por um conjunto de questões, que são submetidas às pessoas com o propósito de obter informações sobre temas subjetivos e objetivos. Os questionários foram aplicados aos docentes que trabalham com projetos de leituras nas bibliotecas escolares selecionadas. Antes de serem aplicados aos professores, os questionários foram testados com três professores (pré-teste) que aprovaram o instrumento de pesquisa. 
O pré-teste foi realizado dia 27/09/2014, com uma professora do ensino médio e duas do ensino fundamental. As duas últimas preencheram o questionário sem problemas, não apresentando dúvidas ou sugestões para o instrumento. A professora do ensino médio questionou sobre a quantidade de alternativas que podiam ser marcadas na pergunta número quatro - "Como as atividades de leitura na sua disciplina são planejadas e realizadas?". Diante disso, incorporou-se na pergunta a observação: "Marque somente uma questão".

O questionário buscou responder aos objetivos da presente pesquisa: conhecer a concepção pedagógica sobre a biblioteca escolar e como elas desenvolvem projetos de animação e promoção da leitura na escola. Formularamse, no total, 11 perguntas de múltipla escolha, assim divididas:

- As que permitiram conhecer a dinâmica de trabalho entre os docentes e a BE.

- As que permitiram conhecer quais são as competências e estratégias de leitura usadas na promoção da leitura.

- As que permitiram conhecer a contribuição da BE no ranking do Enem.

Os dados foram tabulados no aplicativo Excel, posteriormente, tabulados e convertidos em gráficos de barra e gráficos de porcentagem. Algumas perguntas foram analisadas separadamente, enquanto outras perguntas foram agrupadas e analisadas conjuntamente, porque seus conteúdos se complementavam, o que permitiu fazer algumas comparações pela natureza da amostra "colégios públicos" e "colégios privados".

\subsubsection{Caracterização da amostra}

Amostra é uma parcela convenientemente selecionada do universo de possibilidades de pesquisa. É um número representativo do universo, que pode ser selecionado a partir de duas alternativas: a amostragem probabilista e a não probabilística (MARCONI; LAKATOS, 1999). A amostragem não probabilistica é a que não utiliza fórmulas aleatórias de seleção. Para a presente pesquisa, a amostragem é não probabilística intencional. No caso, é a mais adequada, visto que 
o pesquisador está interessado em um grupo da população não representativo. "O pesquisador escolhe elementos representativos da população geral considerando aspectos de representatividade, cargo ocupado, prestígio, etc." (MARCONI; LAKATOS, 1999, p. 37).

Inicialmente, a amostra foi constituída pelas cinco melhores escolas do ranking Nacional do Enem de 2013, compostas por duas escolas de São Paulo, uma do Rio de Janeiro e duas de Minas Gerais, quais sejam:

$$
\begin{aligned}
& \text { 1 lugar: Objetivo Colégio Integrado - SP } \\
& \text { 2ำ lugar: Colégio Bernoulli - Unidade Lourdes - MG } \\
& \text { 3 lugar: Colégio e Curso Ponto de ensino - RJ } \\
& \text { 4ํlugar: Vértice Colégio Unidade II - SP } \\
& \text { 5 lugar: Colégio Santo Antonio - MG }
\end{aligned}
$$

Após a seleção da amostra, no mês de setembro de 2014, iniciaram-se os contatos com a bibliotecária do Colégio Objetivo de São Paulo (SP), 1ํ lugar no ranking. No mês de outubro, diante da resposta positiva da bibliotecária, a pesquisadora viajou para SP, mas, infelizmente, não foi possível aplicar o formulário e os questionários, porque a direção da escola não autorizou a pesquisa, com a alegação de que só podiam participar de pesquisas os estudantes da Universidade Paulista (Unip).

Entrou-se em contato, via e-mail, com o Colégio São Bento do Rio de Janeiro. Após mais de 15 dias esperando resposta, a bibliotecária do colégio respondeu negativamente com o argumento de não poder contribuir com a pesquisa, devido às inúmeras solicitações de pesquisas de mestrado e doutorado.

Entrar em contato com os bibliotecários de colégios privados foi uma tarefa árdua. As secretárias das escolas solicitavam o envio de um e-mail para a coordenação geral, que o passava para a bibliotecária. Contudo, muitas vezes, a coordenação não passava o e-mail para a bibliotecária e, em muitas situações, um mês não foi o suficiente para o contato. Pela demora nas respostas, juntamente com as questões de distância e financeiras, a amostra foi alterada com o objetivo de contemplar os cinco melhores colégios privados do ranking do Enem 2013 do Distrito Federal (DF), quais sejam: 


\author{
10 lugar: Colégio Olimpo \\ 2o lugar: Colégio Galois \\ 3 lugar: Colégio Pódium \\ 4 lugar: Centro Educacional Sigma Asa Sul \\ 5o lugar: Centro Educacional Sigma Asa Norte
}

Contudo, dois dos colégios do Distrito Federal que constam no primeiro e terceiro lugar no ranking do ENEM - o Colégio Olimpo e o Colégio Pódium manifestaram não possuir biblioteca nos estabelecimentos, contando somente com uma sala de leitura. Explicaram também que os livros de consulta que os estudantes utilizam são entregues pelo colégio. Ademais, o Centro Educacional Sigma da Asa Norte não autorizou a pesquisa.

Os colégios Galois e Sigma da Asa Sul, 20 e 4ํ lugares do ranking do Enem 2013, autorizaram a pesquisa. Além deles, o colégio Vértice de São Paulo, 4 lugar do ranking nacional do Enem 2013, também concordou com a pesquisa. Vale ressaltar que os trâmites burocráticos para obtenção da autorização foram muitos. Diante dessa realidade, emergiram algumas perguntas: "são os mesmos trâmites burocráticos para acessar às bibliotecas escolares dos colégios públicos?" "Como funcionam as bibliotecas dos colégios públicos?" Decidiu-se, então, ampliar a amostra para contemplar colégios públicos do Distrito Federal.

Os três outros colégios incluídos na amostra - Colégio Militar de Brasília - 17º lugar; Centro de Ensino Médio do Setor Oeste (CEM) - 90 olugar e o Centro de Ensino Médio da Asa Norte (CEAN) em 95ㅇl lugar - estão entre os seis primeiros colocados do ranking do Enem 2013 na categoria de escolas públicas do Distrito Federal. Destaca-se que o ranking das melhores escolas do Distrito Federal de 2013 mostra que somente dez escolas públicas estão entre as 100 melhores. Mais ainda, essas escolas públicas não foram avaliadas entre as dez primeiras posições do ranking.

O acesso às bibliotecas dos colégios públicos foi mais fácil e ocorreu da mesma forma nas três instituições. Na primeira visita, houve entrevista com o coordenador pedagógico da escola para apresentação dos objetivos da pesquisa e obtenção da autorização para a aplicação dos instrumentos de coleta de dados: o 
questionário e o formulário. No mesmo dia, houve contato com o responsável pela biblioteca e agendamento das datas das visitas.

Pelo exposto, a amostra desta pesquisa, representada no Quadro 09, compõe-se das:

- Três escolas particulares avaliadas nas seis primeiras posições do ranking do Enem, sendo uma do ranking nacional e duas do ranking de Brasília.

- Três escolas públicas avaliadas nas seis primeiras posições do ranking do Enem na categoria pública.

Quadro 09- Ranking das escolas pesquisadas

\begin{tabular}{|l|l|l|l|}
\hline UF & Rede & Unidade escolar & Média \\
\hline SP & Privada & Colégio Vértice & 715.41 \\
\hline DF & Privada & Colégio Galois & 658.32 \\
\hline DF & Privada & CED Sigma & 650.28 \\
\hline DF & Federal & Colégio Militar de Brasília & 606.60 \\
\hline DF & Estadual & CEM Setor Oeste & 522.92 \\
\hline DF & Estadual & CEM Asa Norte - CEAN & 517.06 \\
\hline
\end{tabular}

Fonte: INEP (2014) ${ }^{12}$

Nas escolas listadas no quadro 09, os instrumentos de coleta de dados foram aplicados aos bibliotecários e docentes das escolas.

\footnotetext{
${ }^{12}$ http://portal.inep.gov.br/web/enem/enem-por-escola
} 


\section{ANÁLISES DOS RESULTADOS}

Capítulo

\subsection{Análise documental}

É importante conhecer como a escola comtempla a questão da concepção da biblioteca escolar, a formação autônoma dos estudantes no uso da informação e o ensino de leitura no seu projeto político-pedagógico. Nos sites dos colégios, na publicidade impressa, nos documentos secundários, encontrarmos informações acerca do projeto pedagógico e dos projetos extracurriculares que foram muito úteis para a seguinte análise.

\subsubsection{Colégio Vértice - São Paulo}

O Colégio Vértice foi fundado, em 1976, na cidade de São Paulo, pela pedagoga Walkiria Gattermayr Ribeiro. A proposta pauta-se na formação integral, em que as atitudes são tão importantes quanto os conteúdos. De acordo com Balbino (2010), o Colégio Vértice informa que:

O colégio possui um sistema de avaliação em que os alunos são avaliados em relação aos conteúdos estudados e também frente às suas responsabilidades e obrigações, estimulando o respeito aos colegas, professores e funcionários da escola. Portanto, é um sistema que privilegia a formação integral do aluno (BALBINO, 2010, p.27).

As dependências da escola compõem-se de: salas de aula, auditório, biblioteca, laboratório, pátio de lanche, quadra poliesportiva.

Fotografia 01 - Pátio da escola - Vértice

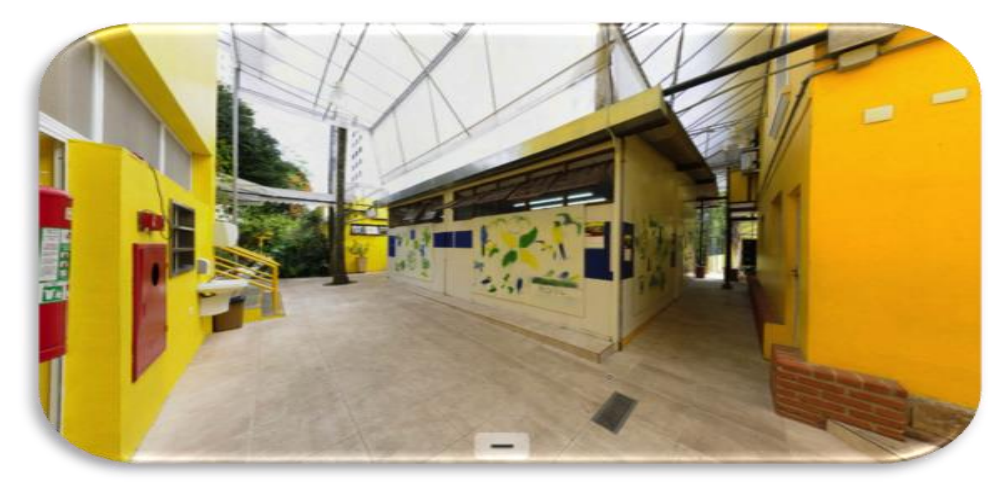

Fonte: http://colegiovertice.com.br/. 
A escola considera importante conhecer como o estudante chegou ao conhecimento e aprofundou o que sabia a partir dos conhecimentos prévios. Pressupõe que o conhecimento se constrói por meio da relação entre o homem e o mundo, constituindo-se produto da interação de ambos. Os objetivos do colégio são formar cidadãos competentes no aprendizado da leitura e da escrita, incentivar o hábito de estudo e autonomia, com ênfase na importância das responsabilidades com os compromissos assumidos e tarefas do cotidiano.

O colégio Vértice apresenta método próprio de alfabetização, desenvolvido pela fundadora da escola. A escrita é introduzida de forma sistemática, porém, lúdica, por meio de atividades que despertam a vontade de ler e escrever. A pedagoga e fundadora do Colégio Vértice, Walkiria Gattemayr Ribeiro, desenvolveu um método próprio de alfabetização (...) em que a introdução da escrita ocorre por meio de atividades que despertam a vontade de ler e escrever de forma sistêmica e lúdica. Além disso, as aulas estimulam a autonomia da criança em atividades como lições e tarefas do dia a dia, assim como no contato com diversos livros de leitura que complementam a alfabetização, levando o aluno a interpretar pequenos textos de forma independente. ${ }^{13}$

No térreo situa-se a biblioteca composta por quatro espaços: espaço da leitura, sala de coleção, sala da "hora do conto", espaço para atividades administrativas. A figura 2 mostra a sala de consulta da biblioteca.

Fotografia 2 - Biblioteca - Vértice

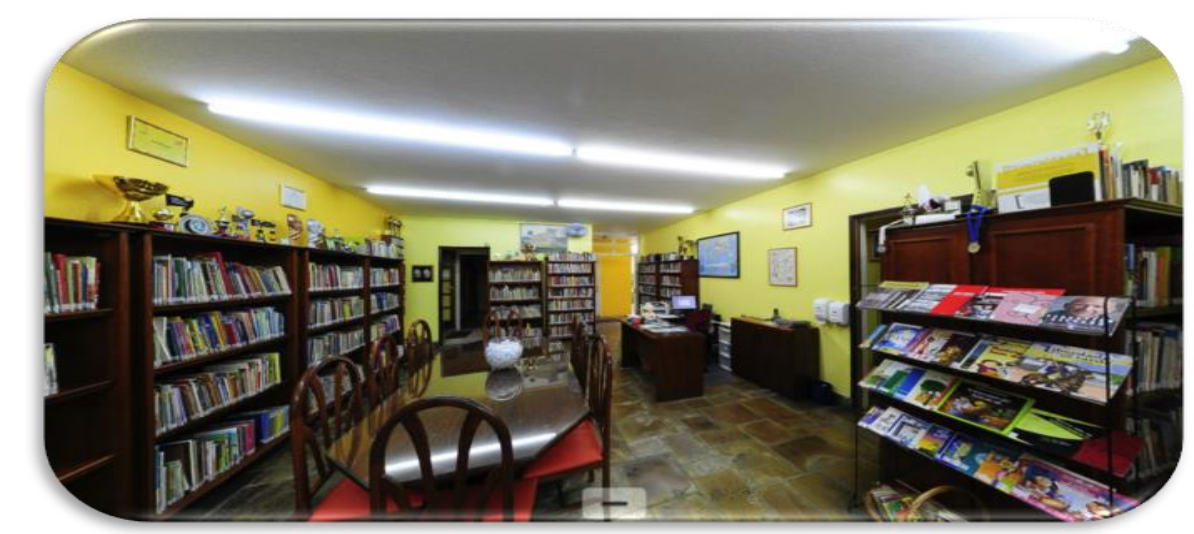

Fonte: $\underline{\text { http://colegiovertice.com.br/. }}$.

\footnotetext{
${ }^{13}$ http://colegiovertice.com.br/. Acesso em: 12/12/2014.
} 
A biblioteca, a interpretação leitora e a redação tornam-se importantes no processo de aprendizagem e são mencionadas em muitas partes dos documentos publicitários da escola. Por exemplo, dentro da matriz curricular da Educação Infantil, encontram-se aulas de leitura interpretativa. A biblioteca escolar conta com ambiente para realizar "contações" de histórias, há roupas dos personagens e muitos outros recursos para que os estudantes desenvolvam o gosto pela leitura. A escola apresenta um projeto de leitura realizado em parceria com a biblioteca e os professores de Ensino Fundamental.

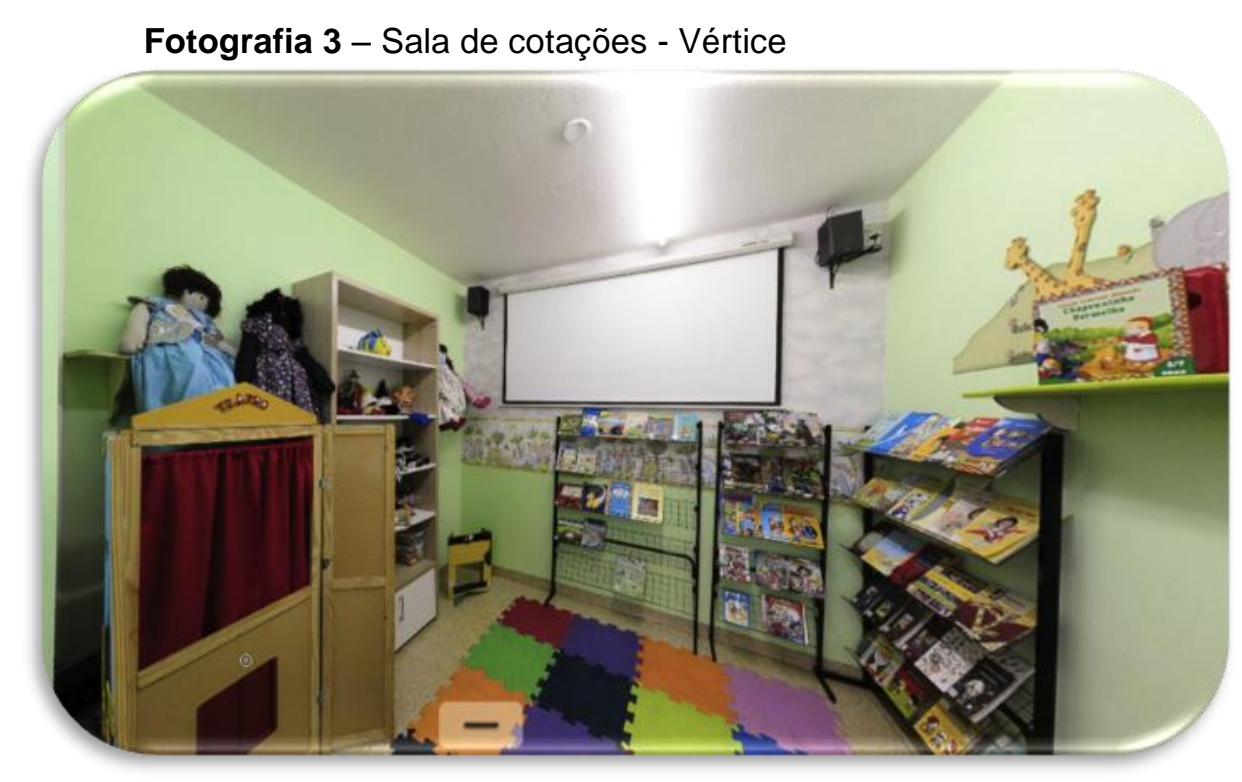

Fonte: http://colegiovertice.com.br/.

Caraterísticas principais do Colégio Vértice:

- Colégio particular.

- Voltado para a Educação Infantil, Ensino Fundamental e Ensino Médio.

- Método exclusivo de alfabetização.

- 40 lugar no ranking nacional do ENEM 2013, e 2o lugar no ranking de São Paulo.

- Apresenta biblioteca com sala de contação de histórias.

- Espaço Cultural Vértice aberto aos estudantes, pais e à comunidade

- Desenvolve projetos e atividades de leitura com alunos de Ensino Fundamental em parceria com a biblioteca. 


\subsubsection{Colégio Galois}

O Instituto Evariste Galois, ou simplesmente Galois, foi fundado em 1996. O nome faz referência ao matemático francês Evariste Galois. As dependências da escola compõem-se de:

30 salas de aula, 3 auditórios, 1 laboratório multidisciplinar, 4 salas de orientação, 2 salas de professores, 2 bibliotecas, 2 secretarias, 3 salas de direção, 6 salas de administração, salas para atendimento de enfermagem, odontológico e de fisioterapia, 1 quadra poliesportiva coberta, 1 quadra poliesportiva descoberta, 2 lanchonetes, 1 restaurante, 14 banheiros, 1 almoxarifado, 30 data-shows com tela interativa; 4 lousas eletrônicas (GALOIS, 2012, p12).

Fotografia 4 - Frente do Colégio Galois.

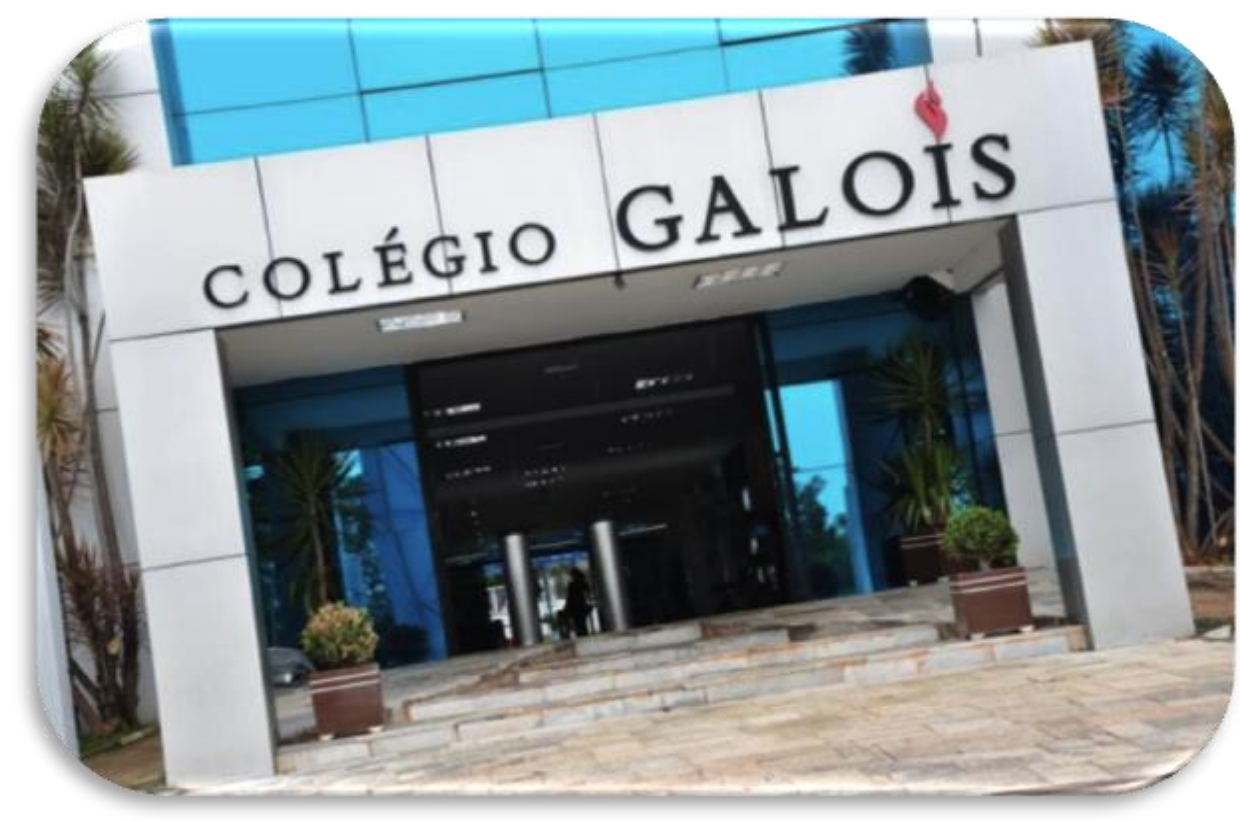

Fonte: http://www.galois.com.br/ensino-medio.

A concepção pedagógica da escola incentiva o desenvolvimento da autonomia moral e intelectual dos alunos mediante educação linear e cooperativa. Estudantes e professor assumem a postura de pesquisador, permitindo a construção do conhecimento (GALOIS, 2012). A partir dessa concepção, espera-se que os estudantes tenham respostas corretas, não porque alguém Ihes mostrou, mas porque as encontrou. 
O objetivo do ensino proposto pelo Colégio Galois é "libertar os alunos das convenções, do autoritarismo das ideias que padronizam, da obediência cega e do comodismo. Orienta a ação do aluno para a construção de conhecimentos, propicia a criticidade e a reflexão" (GALOIS, 212, P.13). Nos documentos do colégio foram observadas descrição de atividades com o objetivo de possibilitar o desenvolvimento integral dos estudantes por meio do estímulo à pesquisa e à criatividade.

No que se refere à Biblioteca e à leitura, os documentos da proposta pedagógica mencionam a infraestrutura e os equipamentos das duas bibliotecas que compõem o sistema de ensino: Biblioteca do Ensino Fundamental e Biblioteca do Ensino Médio. A leitura é mencionada em várias partes como se observa nos

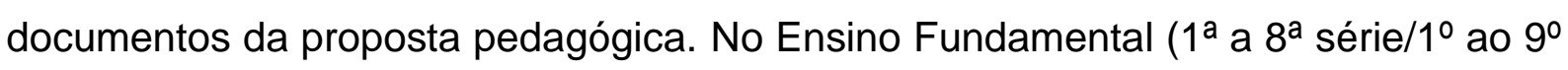
ano), tem-se como um dos objetivos:

- "Desenvolver no aluno a capacidade de aprender a aprender, ao utilizar meios e métodos significativos para o domínio da leitura, da escrita e do cálculo, para a aquisição de conhecimentos e habilidades" (GALOIS, 2012, p.7).

No caso do Ensino Médio, os objetivos pedagógicos são:

- "Desenvolver o raciocínio lógico e a capacidade de leitura e interpretação, o que leva o aluno a alcançar níveis mais profundos de entendimento, diferenciando-o dos demais jovens desse nível de ensino" (GALOIS, 2012, p.8).

A visita à biblioteca do Ensino Médio mostrou atividades centradas em pesquisas bibliográficas para os diferentes projetos do colégio e, de acordo com relato do coordenador pedagógico, as atividades de promoção da leitura são desenvolvidas também na Educação Infantil no Le Petit Galois. 


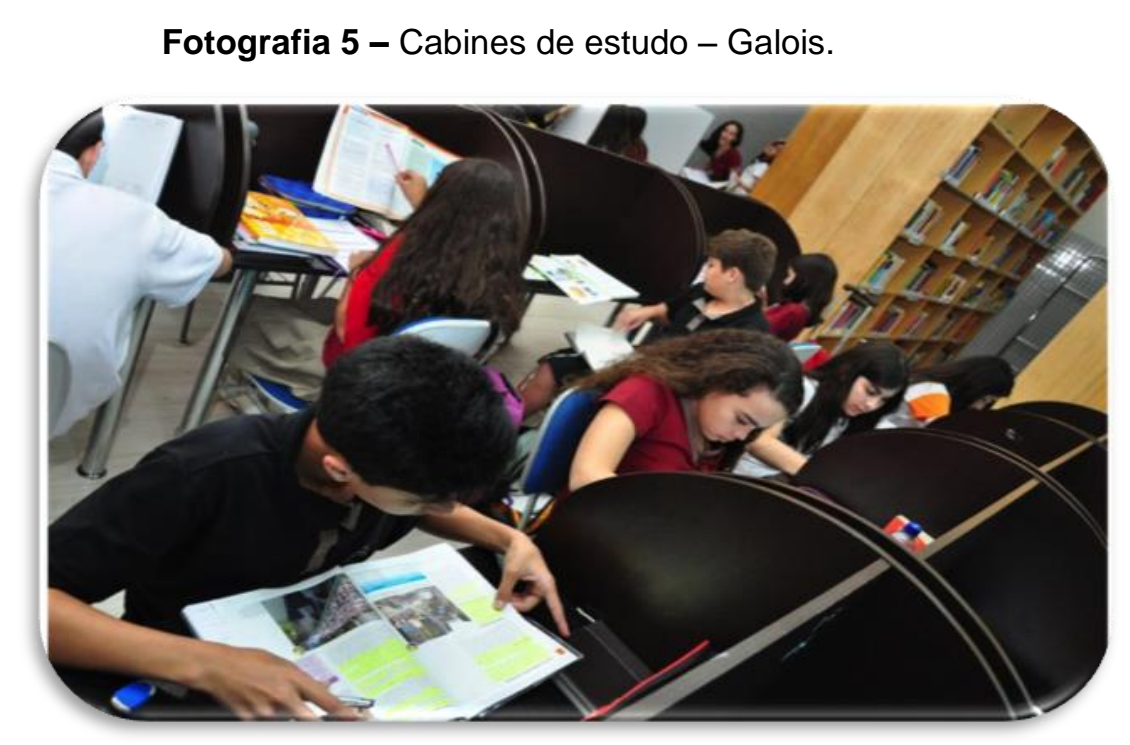

Fonte: http://www.galois.com.br/ensino-medio.

Caraterísticas:

- Colégio particular.

- Voltado para a Educação Infantil, Ensino Fundamental e Ensino Médio.

- 2o lugar no ranking do ENEM 2013 no Distrito Federal - Brasília.

- Possui duas bibliotecas - uma para Ensino médio e outra para o fundamental.

- Projeto que promove a pesquisa: O SIMULOIS.

\subsubsection{Centro Educacional Sigma}

O Centro Educacional SIGMA foi fundado em 1983. O primeiro ano de funcionamento foi 1984. O nome SIGMA vem da letra grega (S) que, em matemática, tem o significado de SOMATÓRIO.

As dependências da escola compõem-se de: Sala de estudos (com atendimento de professores e de monitores), conjunto de laboratórios: Física, Química e Biologia, Laboratório de Informática, sala de aulas, auditório, cinco quadras poliesportivas, cantina e restaurante. O SIGMA dispõe de armários para os estudantes em todos os prédios. ${ }^{14}$

\footnotetext{
${ }^{14}$ http://www.sigma-df.com.br/recursos.php.
} 
Fotografia 6 - Prédio da 3ํㅗㄹ série do Ensino Médio e visão parcial da área verde do SIGMA

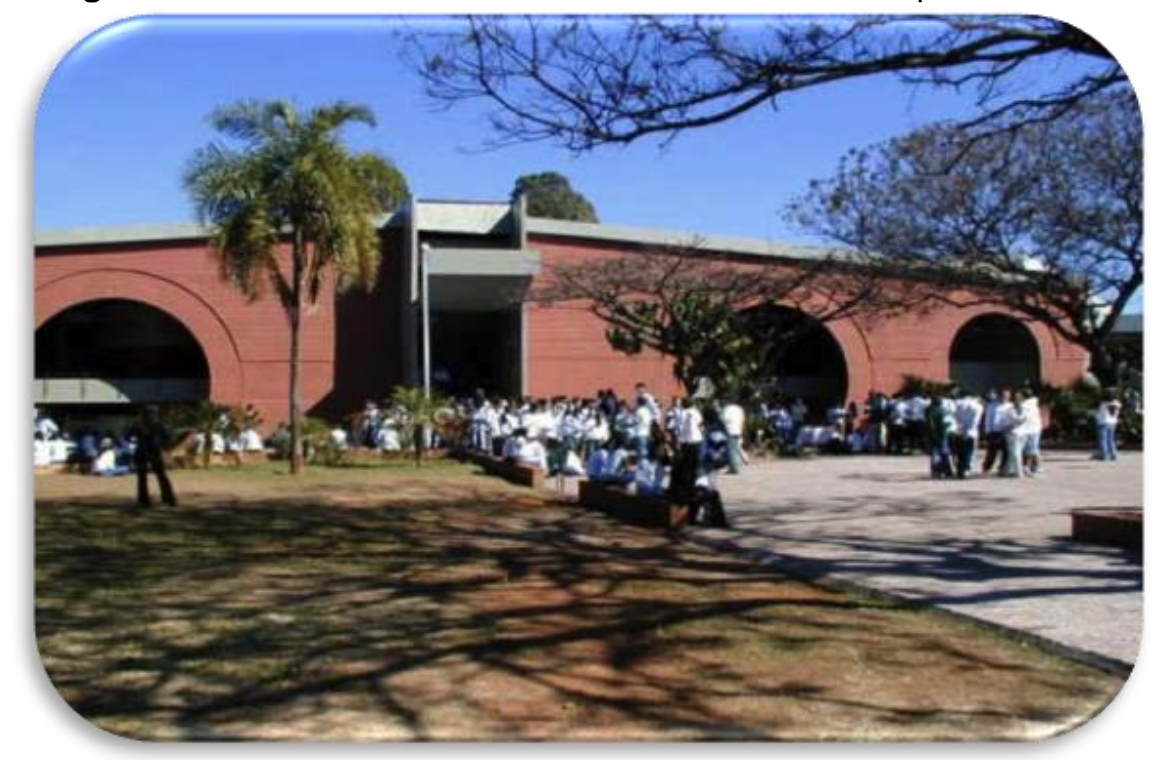

Fonte: http://www.sigma-df.com.br/recursos.php.

A proposta pedagógica do Centro Educacional SIGMA apresenta como objetivo geral, "proporcionar à criança, ao pré-adolescente e ao adolescente uma formação integral para que, na vida adulta, possam exercer sua ação transformadora por meio do trabalho" (SIGMA, s/d ${ }^{15}$ ). Além do objetivo geral, cada nível tem objetivos específicos que se relacionam com a formação de estudantes autônomos, orientando-os no caminho do conhecimento, estimulando-os a raciocinar e a buscar novas informações, assim como interagir em ambientes sociais diversos, os objetivos antes mencionados respondem na proposta pedagógica construtivista integradora e transformadora conforme vão avançando os níveis de ensino os alunos vão definindo seus próprios conceitos.

No momento em que se aplicaram os formulários e questionários, o colégio SIGMA estava em processo de mudanças, pois, em julho 2013, a escola foi comprada pelo grupo empresarial Abril Educação, que implementará o programa "The Leader in Me" (O Líder em Mim) no Ensino Fundamental I e II. O programa é baseado no consagrado livro Os 7 Hábitos de Pessoas Altamente Eficazes, de Stephen Covey, adaptado para uso em escolas de nível básico.

Nessa pesquisa, buscaram-se informação sobre a biblioteca escolar e os projetos de leitura. A BE do colégio, no momento da pesquisa, havia entrado em processo de informatização, organização, catalogação e, de acordo com a

${ }^{15}$ http://portal.sigmadf.com.br/Main/Page/PortalSIGMA/Historico-e-Filosofia-1. 
bibliotecária responsável, muitos projetos seriam implementados em 2015. Em relação aos projetos de leitura, não existe projeto que integre as áreas pedagógicas e a biblioteca, mas existem atividades de animação da leitura promovidas pelos docentes. Por exemplo, no referente à promoção da leitura no programa "O Líder em Mim", os estudantes estudam, aplicam e vivenciam os 7 Hábitos, que motivam a leitura do livro, em todas as séries, sendo esse projeto transversal às disciplinas. Cada atividade do nível um usa conhecidas obras populares da "literatura infantil" para ensinar um dos 7 hábitos para as crianças de seis anos. O livro do professor inclui estratégias de leitura a serem usadas antes, durante e depois da leitura. Um modelo de projeto que poderia ser integrado ao trabalho da biblioteca.

No térreo, situa-se a biblioteca, um ambiente não muito grande, que conta como uma sala onde fica o espaço de leitura e os terminais conectados à Internet, bem como a coleção bibliográfica e audiovisual.

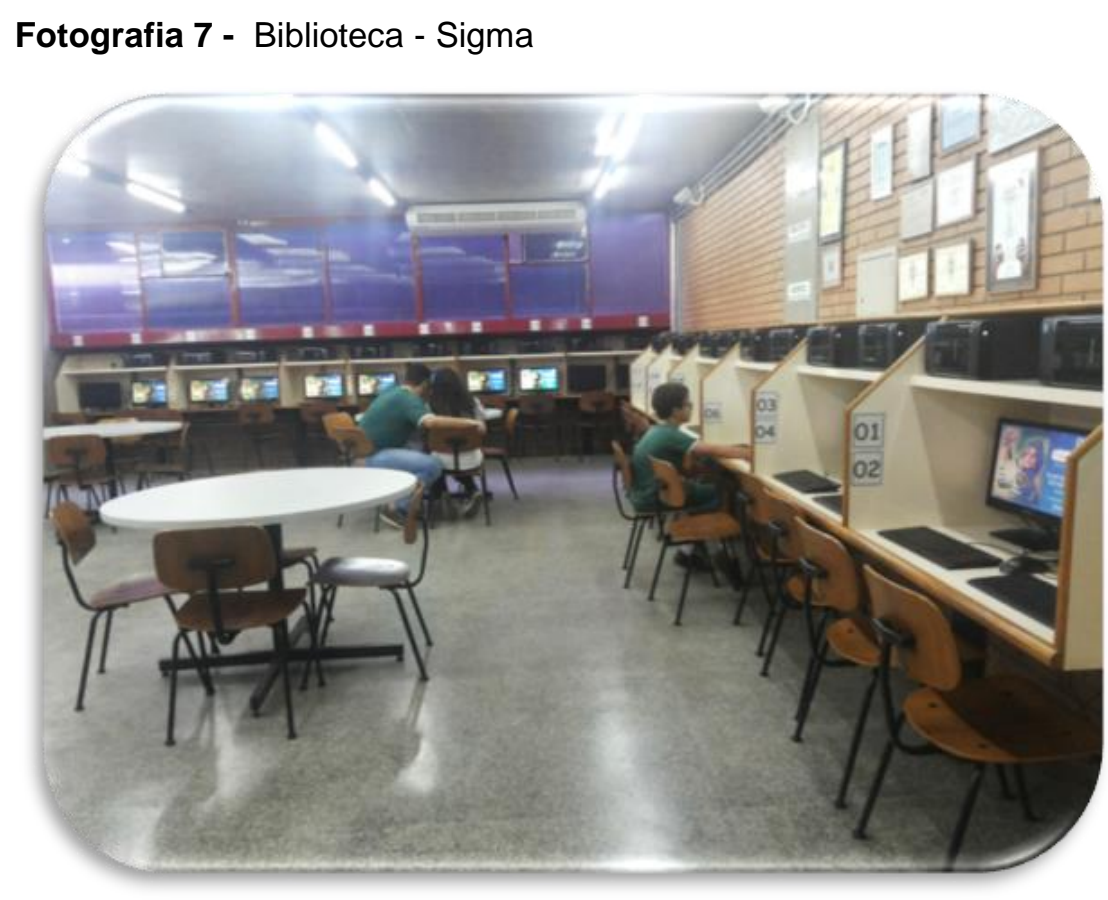

Fonte: Própria

Caraterísticas:

- Colégio particular.

- Voltado para a Educação Infantil, Ensino Fundamental e Ensino Médio.

- 4o lugar no ranking do ENEM 2013 no Distrito Federal - Brasília.

- Possui biblioteca. 
- Projetos e atividades de leitura: Ciranda de livros "era uma vez", livro digital de contos.

\subsection{Colégio Militar de Brasília}

Com o Decreto 81.248, de 23 de janeiro de 1978, foi determinada a criação do Colégio Militar de Brasília (CMB), com sede na Capital Federal. As atividades de ensino iniciaram-se em 05 de março de 1979.

As dependências da escola compõem-se de uma área de aproximadamente 240.000 metros quadrados. Desse total, $60.000 \mathrm{~m} 2$ são áreas em alvenaria e abrigam nas instalações aproximadamente 3.500 estudantes, distribuídos em cerca de 100 salas de aula. Possui campo de futebol, ginásio poliesportivo com nove quadras, mais cinco quadras de esportes como tênis, vôlei, handebol, basquetebol e futsal, além de uma academia de musculação, sala de judô e sala de esgrima. ${ }^{16}$

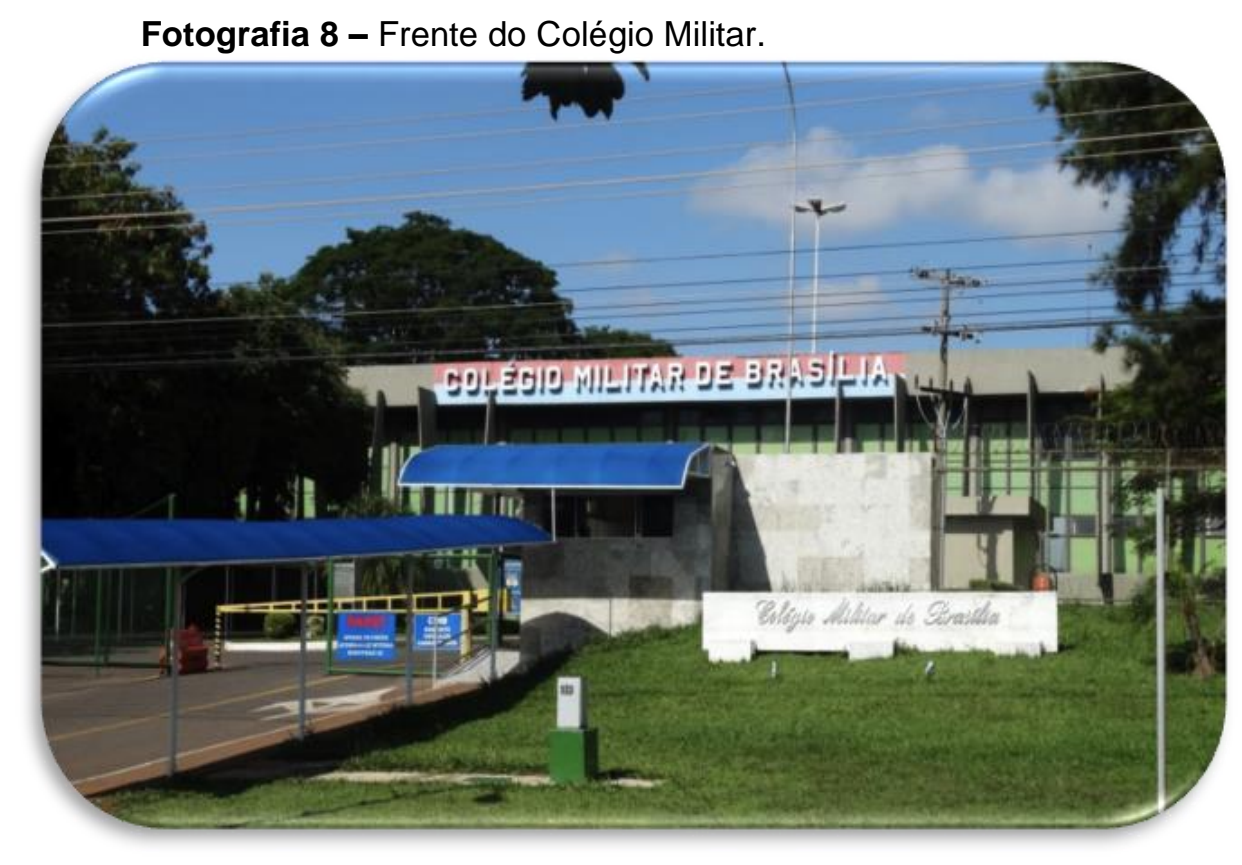

Fonte: elaboração própria.

As práticas didático-pedagógicas nos Colégios Militares subordinam-se às normas e prescrições do Sistema de Ensino do Exército e, ao mesmo tempo, obedecem à Lei de Diretrizes e Bases da Educação Nacional (LDBEN), principal referência que estabelece os princípios e as finalidades da educação no País.

\footnotetext{
${ }^{16}$ http://escolasmilitares.blogspot.com.br/2011/06/o-colegio-militar-de-brasilia-sua.html.
} 
O CMB tem como objetivo a formação integral de cidadãos autônomos, éticos, solidários e atuantes social e politicamente, por intermédio do trabalho e do desenvolvimento dos campos afetivo, cognitivo e psicomotor. Tal ideal pode ser visto refletido na proposta pedagógica voltada à formação integral dos estudantes. "Mais do que facilitar o acesso ao conhecimento, o CMB objetiva à formação integral de cidadãos autônomos, éticos, solidários e atuantes social e politicamente por intermédio do trabalho e do desenvolvimento dos campos afetivo, cognitivo e psicomotor". ${ }^{17}$

No que se refere ao tema de leitura, consta na proposta pedagógica do colégio que um dos objetivos da biblioteca escolar é propiciar ao estudante "a busca e a pesquisa continuadas de informações relevantes". O colégio desenvolve projeto de leitura, dirigido pela coordenação de Língua Portuguesa, na "Sala de leitura". O Espaço é equipado com mobiliário adequado e livros para o desenvolvimento do projeto. Na entrevista com o professor responsável, ele afirmou que, para 2015, pretende-se fazer parceria entre os docentes e a biblioteca escolar.

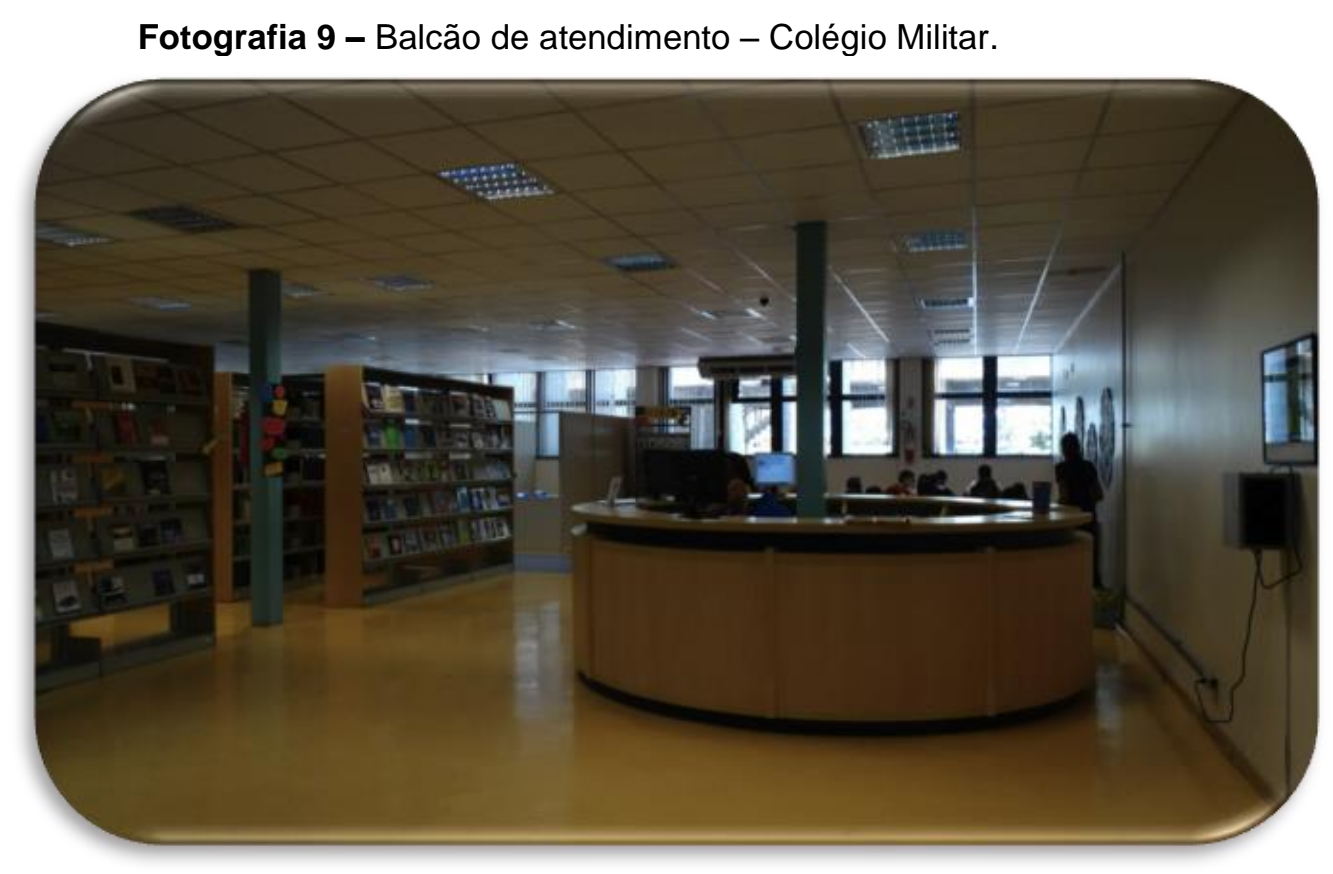

Fonte: Própria.

\footnotetext{
${ }^{17}$ http://www.cmb.ensino.eb.br/.
} 
Caraterísticas:

- Colégio público militar.

- Voltado para o Ensino Fundamental (do 6a ao 9a ano) e o Ensino Médio.

- Normas e diretrizes do Departamento de Ensino e Cultura do Exército Brasileiro.

- Proposta pedagógica de acordo com os Parâmetros Curriculares Nacionais.

- 10 lugar no ranking dos colégios públicos de Brasília no ENEM 2013

- Há biblioteca e sala de contos.

- Produz revista científica.

- Apresenta projeto de leitura com alunos do Ensino Fundamental.

\subsection{Centro de Ensino Médio Setor Oeste}

O Centro de Ensino Médio Setor Oeste foi criado em 1986, com a resolução 163/1986, e é mais conhecido como Cemso. Localizado na SGAS 912/913 Sul, as dependências do Cemso compõem-se de 3 laboratórios, 15 salas de aula, salas para vídeo, uma biblioteca, 8 banheiros, e 1 sala de multimídia.

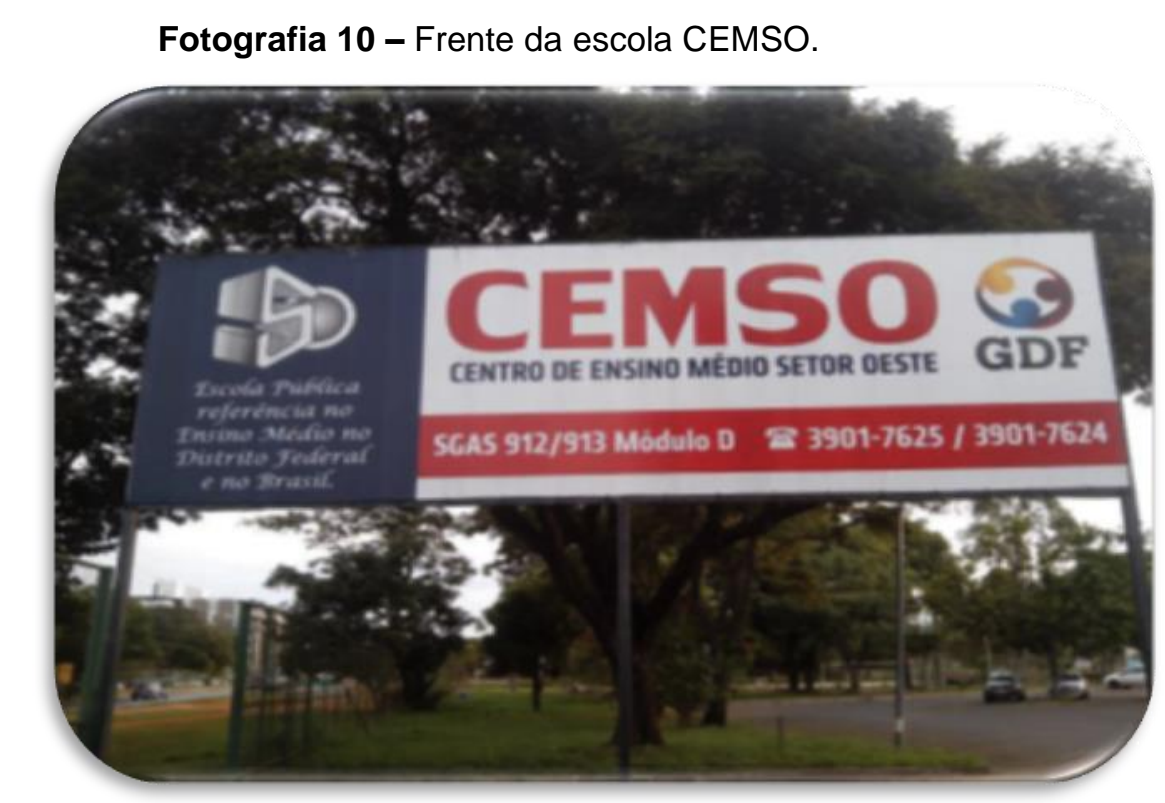

Fonte: CEMSO 2014.

Tem como missão: "A oferta de um ensino público de qualidade com uma proposta que se norteia na diversificação dos conteúdos, contemplando uma formação sólida, crítica e eficaz de uma cidadania crítica e reflexiva" (CEMSO, 2014, 
p.8p). Apresenta proposta pedagógica que visa à formação de qualidade e à inclusão social dos estudantes para que alcancem o nível universitário e vagas no mercado de trabalho. A proposta pedagógica está baseada nas ideias de adquisão de competências propostas por Bernardo Toro (recomendas pela ONU), bem como os Sete Saberes Necessários à Educação do Futuro, postulados por Edgar Morin (CEMSO, 2014, p.7).

A escola trabalha com projetos interdisciplinares e as atividades propostas pelos professores centram-se em fazer com que os estudantes de instituições públicas tenham as mesmas oportunidades que os estudantes dos colégios particulares. Sobre isso, o Cemso apresenta altos índices de ingresso na UnB por meio do Programa de Avaliação Seriada (PAS) e nos resultados da avaliação do Enem.

A escola conta com uma biblioteca, que não está informatizada e não conta com catalogação, nem classificação padronizada. O responsável pela biblioteca é um professor de matéria extinta que orienta os estudantes na pesquisa e na busca de informação. Não há projeto de leitura na biblioteca, mas os estudantes, por conta própria, levam livros de literatura para ler em casa.

Características:

- Escola Pública.

- Nível e Modalidade de ensino ofertado: Ensino Médio, EJA - 1ํ, $2^{\circ}$ e $3^{\circ}$ Segmentos.

- Turno de Funcionamento: Matutino, Vespertino e Noturno.

- Proposta pedagógica de acordo com os Parâmetros Curriculares Nacionais.

- 4ㅇ lugar no ranking dos colégios públicos de Brasília no ENEM 2013.

- Tem biblioteca.

- Projetos interdisciplinares: vídeo-arte, projeto recreio dirigido e projeto Teclarte. Nesses projetos, por exemplo, os estudantes desenvolvem vídeos sobre assuntos apresentados nas aulas de artes, literatura, filosofia e sociologia. 


\subsubsection{Colégio CEAN - Asa Norte}

O Centro de Ensino Médio Asa Norte (CEAN), escola da Rede Pública de Ensino do DF, foi inaugurada 04 de maio de 1981 e integra a estrutura da Secretaria de Educação do Governo do Distrito Federal, vinculada, pedagógica e administrativamente, à Diretoria Regional de Ensino do Plano Piloto e Cruzeiro DRE PP/C.

As dependências do CEAN compõem-se de laboratórios, salas de aula, salas para vídeo, biblioteca, banheiros, sala para professores, auditório, sala de multimídia.

A principal marca da comunidade CEAN é a formação do cidadão crítico e consciente dos direitos e deveres, preparados para colaborar com a construção de uma sociedade mais justa e solidária. A escola se autodefine como atuante, com respeito a diversificação e a apropriação dos conteúdos das diversas áreas. A proposta pedagógica baseia-se no construtivismo. No colégio, trabalha-se de forma interdisciplinar visando ao desenvolvimento, das competências e habilidades dos estudantes para exercerem a cidadania na busca da qualidade social. Por exemplo, o projeto CEAN no Verde ${ }^{18}$ representa uma comunidade comprometida com a Educação Ambiental como meio de alcançar uma vida sustentável que envolve as diferentes áreas da escola com mais de 10 subprojetos.

O CEAN não conta com projeto de leitura que envolva a atuação da biblioteca em parceria com os professores. Os professores desenvolvem atividades de animação da leitura como: intervalo musical, manutenção e organização da sala de leitura, o canto da palavra, feira literária e gincana pedagógica, com quase nenhuma participação da biblioteca. No CEAN, assim como em outros colégios públicos, pode-se observar a falta de investimento em infraestrutura, a falta de capacitação de recursos humanos, etc. A biblioteca não conta com computador, não possui documentos de gestão, nem plano de trabalho.

\footnotetext{
${ }^{18}$ https://sites.google.com/site/oceanoverdedf/Home/o-cean/historia-da-escola.
} 


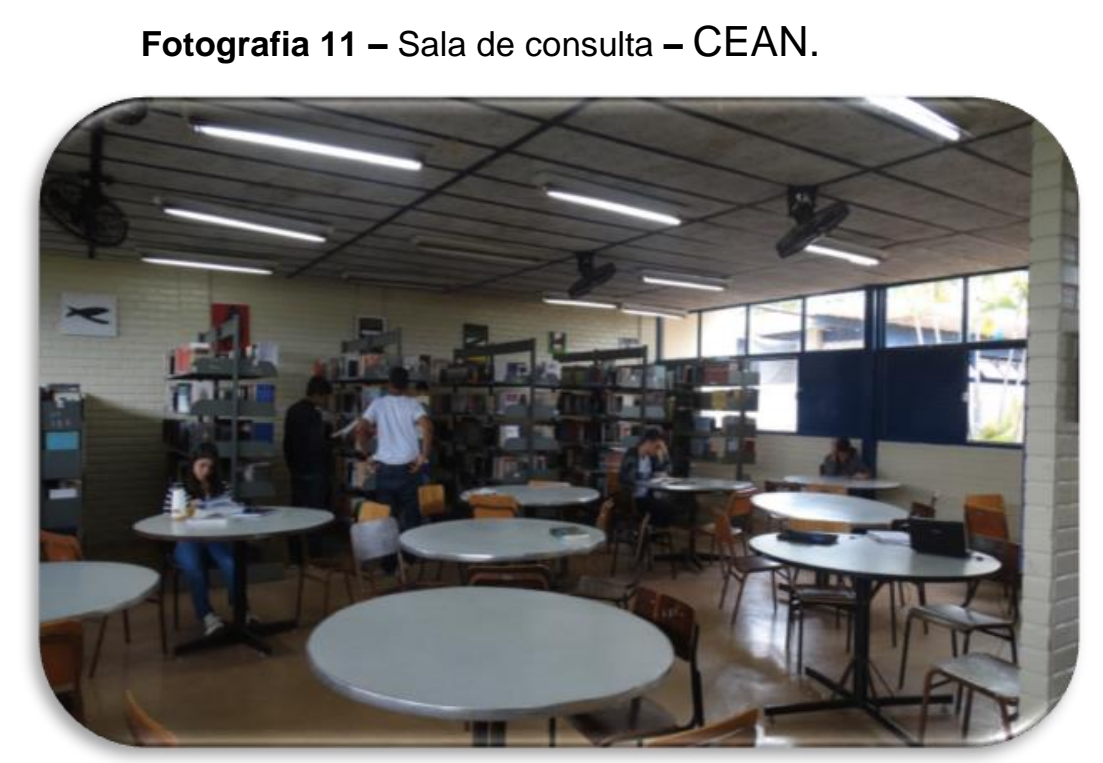

Fonte: Própria

Características:

- Escola Pública.

- Nível e Modalidade de ensino ofertado: Ensino Médio.

- Turnos de Funcionamento: Matutino, Vespertino e Noturno.

- Proposta pedagógica de acordo com os Parâmetros Curriculares Nacionais.

- $7^{0}$ lugar no ranking dos colégios públicos de Brasília no ENEM 2013.

- Tem biblioteca.

- Projetos interdisciplinares: CEAN no Verde, que tem subprojetos em diferentes áreas, tais como, Análise de documentários (Releitura e discussão das realidades sociais).

\subsection{Análises dos formulários e questionários}

A metodologia abrangeu, além da análise documental, questionário e formulário para coleta de dados. Os primeiros foram aplicados aos professores que desenvolveram projetos de leitura e o segundo aos responsáveis pelas bibliotecas. Os colégios foram identificados com a letra "C" seguida de um número correlativo, por exemplo, "C1". O objetivo foi facilitar a leitura de dados dos colégios participantes 
Quadro 10 - Rótulos de identificação das escolas participantes da pesquisa.

\begin{tabular}{|l|c|l|}
\hline \multicolumn{1}{|c|}{ Nome do colégio } & Identificador & \multicolumn{1}{c|}{ Tipo } \\
\hline Colégio Vértice - SP & C1 & Privado \\
\hline Colégio Galois - DF & C2 & Privado \\
\hline Colégio Sigma Asa Sul - DF & C3 & Privado \\
\hline Colégio Militar de Brasília - DF & C4 & Público Federal \\
\hline CEM Setor Oeste - DF & C5 & Público Estadual \\
\hline CEM Asa Norte (CEAN) - DF & C6 & Público Estadual \\
\hline
\end{tabular}

Fonte: elaboração própria.

\subsubsection{Características demográficas dos participantes}

Na pesquisa participaram 18 professores e seis responsáveis pela biblioteca escolar dos seis colégios de Ensino Médio que compõe a amostra da pesquisa. As características demográficas dos entrevistados, nomeadamente, gênero, curso, formação, são descritas a seguir.

\subsubsection{Bibliotecários/funcionários atuantes nas bibliotecas pesquisadas}

Os dados do formulário mostram que dentre os seis profissionais atuantes na biblioteca escolar cinco são do gênero feminino e um do masculino. Os respondentes possuem curso superior, mas havia somente três bachareis em biblioteconomia, isto é, metade da amostra. A seguir apresentam-se os dados tabulados em relação ao gênero, formação e curso.

- Responsável pela biblioteca do C1. Gênero feminino, formação superior, bibliotecária.

- Responsável pela biblioteca do C2. Gênero feminino, formação superior, bibliotecária.

- Responsável pela biblioteca do C3. Gênero feminino, formação superior, bibliotecária.

- Responsável pela biblioteca do C4. Gênero feminino, formação: Tenente.

- Responsável pela biblioteca do C5. Gênero feminino, formação superior, professora de áreas extintas. 
- Responsável pela biblioteca do C6. Gênero masculino, formação superior, professor de áreas extintas.

Dos responsáveis pelas bibliotecas:

Gráfico 1 - Formação acadêmica e tipo de colégio.

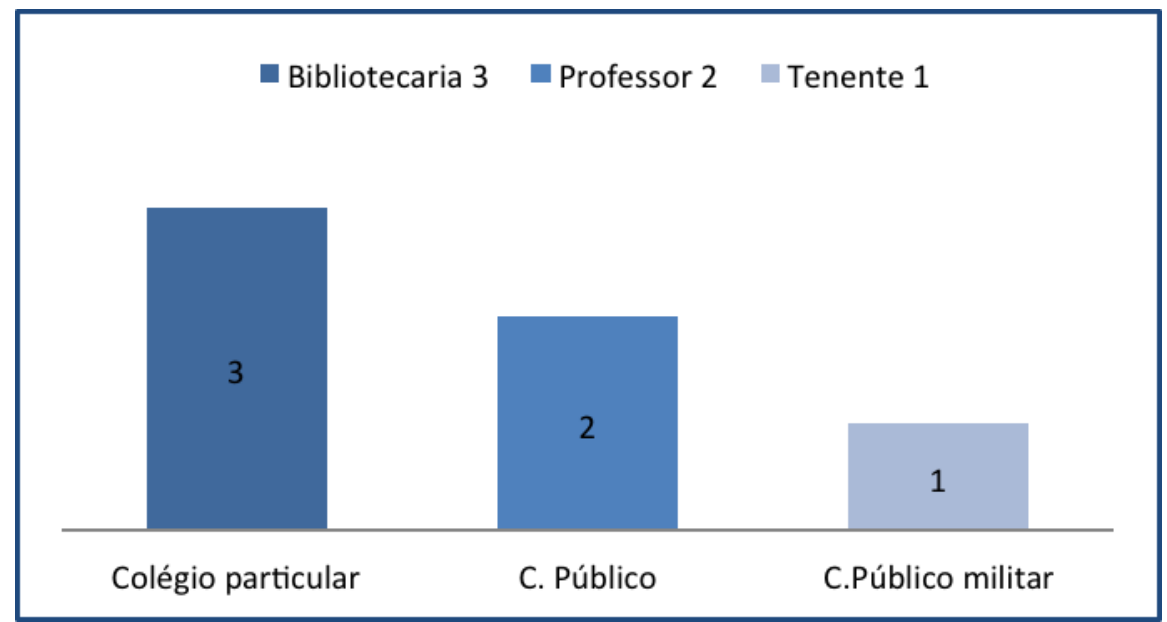

Fonte: Elaboração própria.

\subsubsection{Gênero e área de conhecimento que atuam os professores das escolas pesquisadas}

Os dados do questionário mostram que a amostra foi composta por 18 professores que promovem competências leitoras sendo: oito do gênero feminino e quatro do gênero masculino, que atuam na área de língua portuguesa. Isso demonstra que os trabalhos de leitura ainda são somente responsabilidade dos professores de língua portuguesa.

Gráfico 2 - Gênero e área do conhecimento.

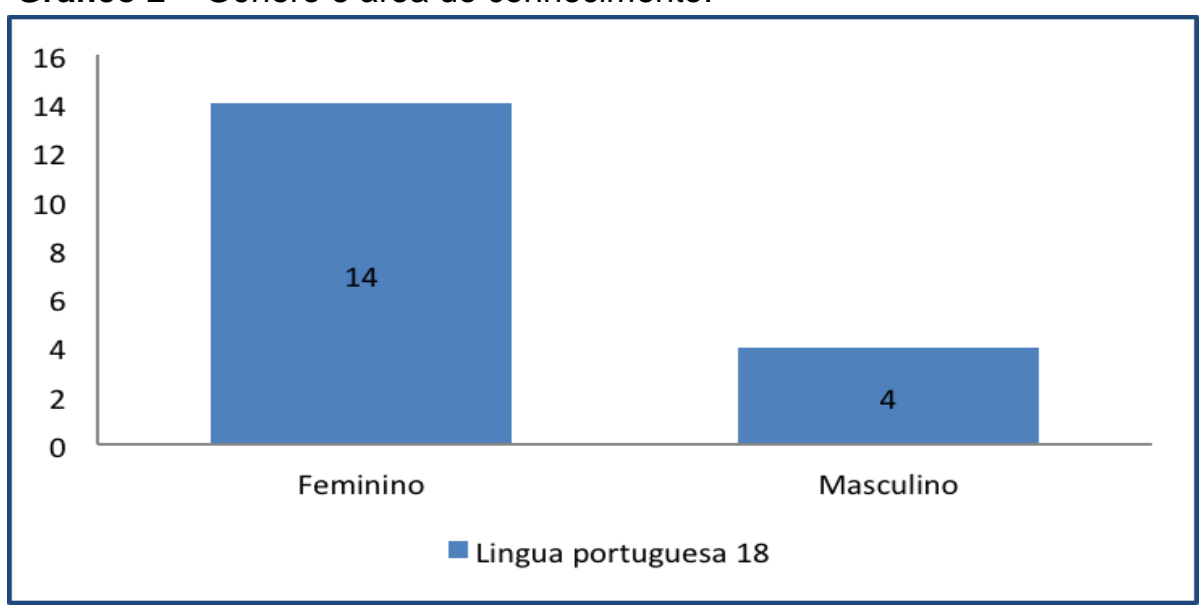

Fonte: Elaboração própria. 
A partir do próximo tópico, os resultados são apresentados, separadamente, de acordo com os dados coletados no formulário e no questionário.

\subsection{Resultados dos formulários}

O formulário foi o instrumento utilizado para coletar dados gerais das bibliotecas como período de funcionamento, espaço físico, acervo e organização, mobiliário e equipamentos, serviços e atividades, além de recursos humanos. As respostas dos formulários foram tabuladas e, posteriormente, pontuadas de acordo com os padrões da avaliação da BE proposto pela GEBE, descritos no quadro 08.

\subsubsection{Funcionamento das bibliotecas}

Por meio do formulário, foi possível descrever os turnos de funcionamento das bibliotecas pesquisadas, o horário de funcionamento e as metas a serem atingidas. Os dados mostram que os seis colégios selecionados proporcionam atendimento aos usuários em todos os turnos. Os dados são apresentados no quadro 11.

Quadro 11- Funcionamento das bibliotecas pesquisadas.

\begin{tabular}{|c|c|c|c|c|}
\hline Colégios & \multicolumn{3}{|c|}{ Funcionamento da Biblioteca } & Meta \\
\hline & $\begin{array}{c}\text { Todos os } \\
\text { turnos (1) }\end{array}$ & $\begin{array}{c}\text { Alguns } \\
\text { turnos (2) }\end{array}$ & $\begin{array}{c}\text { Apenas } \\
\text { um turno (3) }\end{array}$ & \\
\hline C1 & $\mathrm{X}$ & & & 0 \\
\hline C2 & $\mathrm{X}$ & & & 0 \\
\hline C3 & $\mathrm{X}$ & & & 0 \\
\hline C4 & $\mathrm{X}$ & & & 0 \\
\hline C5 & $\mathrm{X}$ & & & 0 \\
\hline C6 & $\mathrm{X}$ & & & 0 \\
\hline
\end{tabular}

Fonte: elaboração própria.

A segunda questão, também relacionada ao funcionamento das bibliotecas, especifica melhor os horários. Os dados mostram que cinco bibliotecas atendem 
com horário regular, que abrange o dia inteiro, inclusive durante o recreio. O colégio C5, ao contrário, atende somente de acordo com a disponibilidade de pessoal, por isso tem como meta propiciar atendimento durante o horário de funcionamento da escola. Os resultados são apresentados no quadro 12.

Quadro 12 - Horário de funcionamento das bibliotecas pesquisadas.

\begin{tabular}{|c|c|c|c|c|}
\hline Colégios & \multicolumn{3}{|c|}{ Funcionamento da Biblioteca } & Meta \\
\hline & $\begin{array}{c}\text { Durante horário } \\
\text { de abertura da } \\
\text { escola, inclusive } \\
\text { recreios (1) }\end{array}$ & $\begin{array}{c}\text { Durante horário } \\
\text { de abertura da } \\
\text { escola, menos } \\
\text { durante o recreio } \\
(2)\end{array}$ & $\begin{array}{c}\text { De acordo } \\
\text { com a } \\
\text { disponibilidade } \\
\text { de pessoal (3) }\end{array}$ & \\
\hline C1 & $\mathrm{X}$ & & & \\
\hline C2 & $\mathrm{X}$ & & & \\
\hline C3 & $\mathrm{X}$ & & & \\
\hline C4 & $\mathrm{X}$ & & $\mathrm{X}$ & 2015 \\
\hline C5 & & & & \\
\hline C6 & $\mathrm{X}$ & & & \\
\hline
\end{tabular}

Fonte: elaboração própria.

\subsubsection{Categoria espaço físico das bibliotecas pesquisadas}

Os itens relacionados ao espaço físico contemplam a localização e metragem dos espaços, bem como as condições de iluminação, acessibilidade, dentre outros. As perguntas buscam dar respostas aos parâmetros de espaço físico suficiente para acomodar o acervo; os ambientes para serviços e atividades para usuários; além dos serviços técnicos e administrativos.

\subsubsection{Localização e metragem das bibliotecas}

A primeira questão do formulário abrange a localização da biblioteca na escola e a metragem do espaço. Os dados mostram que cinco escolas têm localização adequada, somente o colégio C3 não tem localização visível. Entende-se por localização adequada, aquela em que as bibliotecas ficam em local visível, central e de fácil acesso. Três escolas informaram o tamanho das bibliotecas, outras 
três informaram não saber a metragem exata. Contudo, de acordo com a pesquisadora a biblioteca $\mathrm{C} 1$ é visualmente do tamanho da $\mathrm{C} 2$, a C3 do tamanho da C6 e a C4 com aproximadamente 400m2. Os dados são apresentados na tabela 1 .

Tabela 1- Localização e metragem das bibliotecas pesquisadas.

\begin{tabular}{|c|c|c|c|c|}
\hline Colégios & Loca & ização & Metragem & Meta \\
\hline & Adequada & Inadequada & & \\
\hline C1 & $X$ & & $\begin{array}{l}\text { aproximadamen } \\
\text { te } 100 \mathrm{~m} 2\end{array}$ & \\
\hline C2 & $X$ & & $105 \mathrm{~m} 2$ & \\
\hline C3 & & $X$ & $\begin{array}{l}\text { aproximadamen } \\
\text { te } 280 \mathrm{~m} 2\end{array}$ & $\begin{array}{l}\text { Melhora no } \\
2015\end{array}$ \\
\hline C4 & $X$ & & $\begin{array}{l}\text { aproximadamen } \\
\text { te } 400 \mathrm{~m} 2\end{array}$ & \\
\hline C5 & $X$ & & $282 \mathrm{~m} 2$ & $\begin{array}{l}\text { Melhora no } \\
2015\end{array}$ \\
\hline C6 & $X$ & & $162 \mathrm{~m} 2$ & $\begin{array}{l}\text { Melhora no } \\
2015\end{array}$ \\
\hline
\end{tabular}

Fonte: elaboração própria.

\subsubsection{Condições observadas nas bibliotecas}

Em relação ao espaço físico, buscou-se identificar as condições de iluminação, ventilação, limpeza, estética, acessibilidade e segurança. Cada item foi avaliado de acordo com as condições (B) boas; $(M)$ médias e $(R)$ ruins. Além disso, buscou-se conhecer as metas das bibliotecas para esses itens. Observou-se que os colégios $\mathrm{C} 1$, C2 e C4 tem boas condições no que se refere aos itens mencionados. Em termos de estética, a biblioteca do colégio C3 foi o pior colégio avaliado. Considerando todos os itens, a biblioteca do colégio C6 apresenta as piores condições. Além disso, essa biblioteca juntamente com a biblioteca do colégio C5 
foram as únicas que não apresentaram metas de melhoria por não terem previsão de investimento. Os dados são apresentados no quadro 13.

Quadro 13: Condições do espaço físico.

\begin{tabular}{|c|c|c|c|c|c|c|c|c|c|c|c|c|c|c|c|c|c|c|}
\hline \multirow[t]{3}{*}{ Colégios } & \multicolumn{18}{|c|}{ Espaço físico - condições de: } \\
\hline & \multicolumn{3}{|c|}{ Iluminação } & \multicolumn{3}{|c|}{ Ventilação } & \multicolumn{3}{|c|}{ Limpeza } & \multicolumn{3}{|c|}{ Estética } & \multicolumn{3}{|c|}{ Acessibilidade } & \multicolumn{3}{|c|}{ Segurança } \\
\hline & $B$ & $M$ & $\mathrm{R}$ & $B$ & $M$ & $\mathrm{R}$ & $B$ & M & $\mathrm{R}$ & $\mathrm{B}$ & M & $\mathrm{R}$ & $B$ & M & $\mathrm{R}$ & B & M & $\mathrm{R}$ \\
\hline C1 & $X$ & & & $X$ & & & $X$ & & & $X$ & & & $X$ & & & $X$ & & \\
\hline $\mathrm{C2}$ & $X$ & & & $\mathrm{X}$ & & & $X$ & & & $\mathrm{X}$ & & & $X$ & & & $X$ & & \\
\hline C3 & $X$ & & & $X$ & & & $X$ & & & & & $\mathrm{X}$ & $X$ & & & $X$ & & \\
\hline C4 & $X$ & & & $X$ & & & $X$ & & & $\mathrm{X}$ & & & $X$ & & & $X$ & & \\
\hline C5 & & $X$ & & & $X$ & & & $X$ & & & $X$ & & & & $X$ & $X$ & & \\
\hline C6 & & & $X$ & & & $X$ & & & $X$ & & $X$ & & & & $X$ & & & \\
\hline
\end{tabular}

Fonte: elaboração própria.

\subsubsection{Espaços existentes na biblioteca}

Em relação ao espaço físico, buscou-se identificar os espaços existentes da biblioteca. Cada item foi avaliado de acordo com as condições Tem; Não tem. Além disso, buscou-se saber as metas das bibliotecas para esses itens. Os dados mostram que as seis bibliotecas pesquisadas contam com espaço para acervo e leitura/pesquisa. A biblioteca do colégio $\mathrm{C} 1$ tem a maior quantidade de espaços, ao contrário, o colégio C5 conta somente com dois espaços. Das seis bibliotecas pesquisadas, apenas uma delas, $\mathrm{C} 1$, tem espaço para leitura infantil. Os dados são apresentados no quadro 14 . 
Quadro 14: Espaços existentes na biblioteca.

\begin{tabular}{|c|c|c|c|c|c|c|c|}
\hline Colégios & $\begin{array}{c}\text { Espaço } \\
\text { para } \\
\text { atendimen } \\
\text { to ao } \\
\text { público }\end{array}$ & $\begin{array}{c}\text { Espaço para } \\
\text { leitura e } \\
\text { pesquisa }\end{array}$ & $\begin{array}{c}\text { Espaço } \\
\text { para } \\
\text { leitura } \\
\text { infantil }\end{array}$ & $\begin{array}{l}\text { Cabines- } \\
\text { salas } \\
\text { individuais } \\
\text { para estudo }\end{array}$ & $\begin{array}{c}\text { Espaço para } \\
\text { atividades } \\
\text { audiovisuais }\end{array}$ & $\begin{array}{c}\text { Espaço } \\
\text { para } \\
\text { computado } \\
\text { res }\end{array}$ & $\begin{array}{c}\text { Espaço } \\
\text { para } \\
\text { acervo }\end{array}$ \\
\hline C1 & $x$ & $x$ & $x$ & & $x$ & & $x$ \\
\hline C2 & $X$ & $x$ & & $x$ & & $x$ & $x$ \\
\hline C3 & $x$ & $x$ & & & & $x$ & $x$ \\
\hline C4 & $x$ & $x$ & & $x$ & $x$ & $x$ & $x$ \\
\hline C5 & & $x$ & & & & & $x$ \\
\hline C6 & $x$ & $x$ & & & & & $x$ \\
\hline
\end{tabular}

Fonte: elaboração própria.

\subsubsection{Mobiliário e equipamentos}

Em relação aos mobiliários e equipamentos, o mobiliário/equipamento mais comum nas bibliotecas é o quadro mural. Nenhuma das bibliotecas conta com filmadora. As bibliotecas dos colégios C5 e C6 não possuem muitos equipamentos básicos tampouco previsão de compra. Os dados podem ser observados no quadro 15.

Quadro 15: Mobiliário e equipamentos.

\begin{tabular}{|l|l|l|l|l|l|l|l|}
\hline \multicolumn{1}{|c|}{ Mobiliário e equipamentos } & C1 & C2 & C3 & C4 & C5 & c6 & Meta \\
\hline Guarda volume & & & & & $\mathrm{X}$ & $\mathrm{X}$ & \\
\hline Estantes expositores & $\mathrm{X}$ & & $\mathrm{X}$ & $\mathrm{X}$ & & $\mathrm{X}$ & \\
\hline Arquivos & $\mathrm{X}$ & & $\mathrm{X}$ & & & & \\
\hline Televisão & $\mathrm{X}$ & & & $\mathrm{X}$ & & & \\
\hline
\end{tabular}




\begin{tabular}{|l|l|l|l|l|l|l|l|}
\hline Mapoteca & & & & $\mathrm{X}$ & & & \\
\hline Quadro mural & $\mathrm{X}$ & $\mathrm{X}$ & & $\mathrm{X}$ & $\mathrm{X}$ & $\mathrm{X}$ & \\
\hline Impressora & $\mathrm{X}$ & & $\mathrm{X}$ & $\mathrm{X}$ & & & \\
\hline Tocador de DVD & $\mathrm{X}$ & & & $\mathrm{X}$ & & $\mathrm{X}$ & \\
\hline Máquina fotográfica & & & & $\mathrm{X}$ & & & \\
\hline Tocador de CD & & & & $\mathrm{X}$ & & & \\
\hline Filmadora & & & & & & & \\
\hline Telefone & & & $\mathrm{X}$ & $\mathrm{X}$ & & & \\
\hline Quadro negro & & & & & & & \\
\hline
\end{tabular}

Fonte: elaboração própria.

\subsubsection{Computadores}

Os dados do formulário mostram que as bibliotecas dos colégios C2, C3 e C4 apresentam computadores conectados à internet para a busca de informação. Os colégios C3 e C4 não forneceram dados sobre a relação computador $x$ alunos. As bibliotecas dos colégios, C1, C5 e C6 não possuem computador para uso dos alunos.

Tabela 2 - Computadores.

\begin{tabular}{|c|c|c|c|c|c|l|}
\hline & C1 & C2 & C3 & C4 & C5 & C6 \\
\hline $\begin{array}{c}\text { Número total de computadores com } \\
\text { acesso a internet }\end{array}$ & 0 & 6 & 23 & 10 & 0 & 0 \\
\hline Relação computador x alunos & 0 & Desconhece & Desconhece & 300 & 0 & 0 \\
\hline Condições de uso dos computadores & - & Boas & Boas & Boas & - & - \\
\hline
\end{tabular}

Fonte: elaboração própria.

\subsubsection{Acervo}

Padrão: A biblioteca conta com acervo de livros compatível com o número de alunos é apresentada na tabela de dados quantitativos do acervo observando-se 
que as 6 bibliotecas tem mais de 6 livros por aluno sendo 4 a medida mínima para ser considerada como do nível exemplar.

Tabela 3 - Dados quantitativo do acervo.

\begin{tabular}{|c|c|c|c|c|c|c|}
\hline \multicolumn{7}{|c|}{ DADOS QUANTITATIVOS DO ACERVO } \\
\hline & $\mathrm{C} 1$ & $\mathrm{C} 2$ & $\mathrm{C} 3$ & $\mathrm{C} 4$ & $\mathrm{C} 5$ & C6 \\
\hline $\begin{array}{l}\text { Número de itens do } \\
\text { acervo }\end{array}$ & 7590 & 4974 & 17000 & 21000 & 10000 & 13000 \\
\hline Número de títulos & 5500 & 4000 & $\begin{array}{c}\text { Não } \\
\text { informaram }\end{array}$ & $\begin{array}{c}\text { Não } \\
\text { informaram }\end{array}$ & 5000 & 11000 \\
\hline $\begin{array}{l}\text { Número de itens do } \\
\text { acervo destinado a } \\
\text { professores }\end{array}$ & 7590 & 4974 & 17000 & 21000 & 320 & 280 \\
\hline $\begin{array}{l}\text { Número de itens do } \\
\text { acervo destinado a } \\
\text { estudantes }\end{array}$ & 7590 & 4974 & 17000 & 21000 & 9680 & 13000 \\
\hline $\begin{array}{l}\text { Número de revistas } \\
\text { informativas } \\
\text { (títulos) }\end{array}$ & 5 & 2 & 8 & 15 & 0 & 5 \\
\hline $\begin{array}{l}\text { Número de jornais } \\
\text { (assinaturas } \\
\text { correntes) }\end{array}$ & 1 & 2 & 2 & 1 & 0 & 0 \\
\hline $\begin{array}{l}\text { Número de } \\
\text { enciclopédias } \\
\text { (títulos) }\end{array}$ & 27 & 1 & 75 & $\begin{array}{c}\text { Não } \\
\text { informaram }\end{array}$ & 10 & 21 \\
\hline $\begin{array}{l}\text { Número de } \\
\text { dicionários }\end{array}$ & 20 & 15 & 120 & $\begin{array}{c}\text { Não } \\
\text { informaram }\end{array}$ & 40 & 91 \\
\hline $\begin{array}{l}\text { Número de } \\
\text { almanaques }\end{array}$ & 2 & 1 & 16 & $\begin{array}{c}\text { Não } \\
\text { informaram }\end{array}$ & 0 & 2 \\
\hline $\begin{array}{l}\text { Número de livros } \\
\text { por aluno }\end{array}$ & 6 & 6 & 6 & 7 & 8 & $\begin{array}{c}\text { Não } \\
\text { informaram }\end{array}$ \\
\hline $\begin{array}{l}\text { Número total de } \\
\text { computadores }\end{array}$ & 0 & 6 & 23 & 10 & 1200 & 0 \\
\hline $\begin{array}{l}\text { Número de } \\
\text { computadores por } \\
\text { aluno }\end{array}$ & 0 & 133 & 60 & 300 & 0 & 0 \\
\hline
\end{tabular}

Fonte: elaboração própria.

\section{3.4.1 Organização da coleção}

As seis bibliotecas têm acervo tombado. Nas bibliotecas dos colégios C5 e C6, só parte do acervo é classificado. A catalogação foi realizada no acervo nas bibliotecas $\mathrm{C} 1, \mathrm{C} 2$ e C4, nas demais foi realizado parcialmente. As bibliotecas dos colégios C1, C2, C3 e C4 têm catálogo informatizado e acesso remoto, no qual os estudantes podem acessar com código de matrícula. Pelo fato de não ter 
computador, os colégios C5 e C6 fazem todo o processo de forma manual. Observase, nos dados no quadro 16, a organização do acervo.

Quadro 16 - Organização do acervo.

\begin{tabular}{|c|c|c|c|c|c|c|}
\hline \multicolumn{7}{|c|}{ ORGANIZAÇÃO DO ACERVO } \\
\hline \multicolumn{7}{|c|}{ Tombamento/Registro } \\
\hline & C1 & $\mathrm{C} 2$ & C3 & C4 & C5 & C6 \\
\hline $\begin{array}{l}\text { Todo o acervo é } \\
\text { tombado/registrado }\end{array}$ & $\mathrm{X}$ & $\mathrm{X}$ & $\mathrm{X}$ & $X$ & $X$ & $\mathrm{X}$ \\
\hline \multicolumn{7}{|c|}{ Classificação } \\
\hline Todo o acervo é classificado & $X$ & $\mathrm{x}$ & $X$ & $X$ & & \\
\hline Parte do acervo é classificado & & & & & $X$ & $\mathrm{X}$ \\
\hline \multicolumn{7}{|c|}{ Catalogação } \\
\hline Todo o acervo é catalogado & $\mathrm{X}$ & $\mathrm{X}$ & & $\mathrm{X}$ & & \\
\hline Parte do acervo é catalogado & & & $X$ & & $X$ & $\mathrm{X}$ \\
\hline \multicolumn{7}{|c|}{ Informatização do catálogo } \\
\hline $\begin{array}{l}\text { Todo o acervo está inserido em } \\
\text { catálogo informatizado }\end{array}$ & $\mathrm{X}$ & $x$ & & $\mathrm{X}$ & & \\
\hline $\begin{array}{l}\text { Parte do acervo está inserido } \\
\text { em catálogo informatizado }\end{array}$ & & & $\mathrm{X}$ & & & \\
\hline Não há catálogo informatizado & & & & & $\mathrm{X}$ & $\mathrm{x}$ \\
\hline \multicolumn{7}{|c|}{ Acesso remoto ao catálogo } \\
\hline $\begin{array}{l}\text { O catálogo de todo o acervo } \\
\text { pode ser acessado } \\
\text { remotamente }\end{array}$ & & $\mathrm{X}$ & $\mathrm{X}$ & $\mathrm{X}$ & & \\
\hline $\begin{array}{l}\text { O catálogo não pode ser } \\
\text { acessado remotamente }\end{array}$ & & & & & $\mathrm{X}$ & $\mathrm{X}$ \\
\hline
\end{tabular}

Fonte: elaboração própria.

\subsubsection{Condições gerais do acervo}

Em relação às condições gerais do acervo, os colégios C1, C2, C3 e C4 avaliaram como boas o equilíbrio entre assuntos. Os itens equilíbrio entre séries ou faixa etária e o estado de conservação foram avaliados como bom em todos os colégios. 
Quadro 17 - Condições gerais do acervo.

\begin{tabular}{|c|c|c|c|c|c|c|}
\hline \multicolumn{7}{|c|}{ CONDIÇÕES GERAIS DO ACERVO } \\
\hline \multicolumn{7}{|c|}{ Equilíbrio entre assuntos } \\
\hline & $\mathrm{C} 1$ & $\mathrm{C} 2$ & C3 & $\mathrm{C} 4$ & C5 & C6 \\
\hline Bom & $\mathrm{X}$ & $\mathrm{X}$ & $x$ & $X$ & & \\
\hline Razoável & & & & & $\mathrm{X}$ & $x$ \\
\hline \multicolumn{7}{|l|}{ Ruim } \\
\hline \multicolumn{7}{|c|}{ Equilíbrio entre séries ou faixa etária dos alunos } \\
\hline Bom & $x$ & $\mathrm{X}$ & $\mathrm{x}$ & $\mathrm{X}$ & $\mathrm{x}$ & $x$ \\
\hline \multicolumn{7}{|l|}{ Razoável } \\
\hline \multicolumn{7}{|l|}{ Ruim } \\
\hline \multicolumn{7}{|c|}{ Estado de conservação } \\
\hline Bom & $x$ & $x$ & $x$ & $x$ & $x$ & $x$ \\
\hline \multicolumn{7}{|l|}{ Razoável } \\
\hline Ruim & & & & & & \\
\hline
\end{tabular}

Fonte. Elaboraçaõ própria.

\subsubsection{Categoria serviços e atividades}

Em relação aos serviços e às atividades, as seis bibliotecas apresentam os serviços básicos de consulta no local, empréstimo domiciliar e orientação individual à pesquisa. As bibliotecas dos colégios C1 e C4 apresentam o maior número de serviços e atividades oferecidas. Somente as bibliotecas do colégio C1 e C4 realizam atividades de leitura como feira de livros, clube de leitura e contação de histórias. Os responsáveis pelas demais bibliotecas afirmaram não ter infraestrutura e que os estudantes do ensino médio são autônomos em relação aos gostos pela leitura. Finalmente, apenas o colégio C6 tem blog da biblioteca, o qual foi criado pelos alunos. Os dados podem ser observados no quadro 18. 
Quadro 18 - Serviços e atividades.

\begin{tabular}{|c|c|c|c|c|c|c|}
\hline \multicolumn{7}{|c|}{ SERVIÇOS E ATIVIDADES OFERECIDAS } \\
\hline & $\mathrm{C} 1$ & $\mathrm{C} 2$ & C3 & C4 & C5 & C6 \\
\hline Consulta no local & $x$ & $X$ & $X$ & $X$ & $x$ & $X$ \\
\hline Empréstimo domiciliar & $X$ & $x$ & $x$ & $x$ & $x$ & $\mathrm{X}$ \\
\hline $\begin{array}{l}\text { Orientação individual à } \\
\text { pesquisa }\end{array}$ & $\mathrm{X}$ & $\mathrm{X}$ & $\mathrm{X}$ & $\mathrm{X}$ & $\mathrm{X}$ & $X$ \\
\hline $\begin{array}{l}\text { Orientação coletiva à } \\
\text { pesquisa }\end{array}$ & & $\mathrm{X}$ & & $\mathrm{X}$ & $\mathrm{X}$ & $X$ \\
\hline $\begin{array}{l}\text { Orientação à pesquisa } \\
\text { na internet }\end{array}$ & & $\mathrm{X}$ & & $X$ & & \\
\hline Visitas orientadas & $\mathrm{X}$ & & $X$ & $X$ & & \\
\hline $\begin{array}{l}\text { Folheto/guia de } \\
\text { biblioteca }\end{array}$ & $\mathrm{X}$ & $\mathrm{X}$ & & $X$ & & \\
\hline Contação de histórias & $X$ & & & & & \\
\hline $\begin{array}{l}\text { Divulgação de novas } \\
\text { aquisições }\end{array}$ & $X$ & $\mathrm{X}$ & & $x$ & $X$ & $X$ \\
\hline Boletim informativo & $x$ & & & & & $X$ \\
\hline Mural & $X$ & & & $X$ & $X$ & $X$ \\
\hline \multicolumn{7}{|l|}{ Exposições } \\
\hline Clube de leitura & & & & $x$ & & \\
\hline Feira de livros & 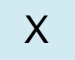 & & & $x$ & & \\
\hline $\begin{array}{l}\text { Encontro com } \\
\text { escritores }\end{array}$ & $X$ & & $X$ & $\mathrm{X}$ & & \\
\hline Palestras & & & $X$ & & & $X$ \\
\hline $\begin{array}{l}\text { Apresentações } \\
\text { artísticas }\end{array}$ & $x$ & & $X$ & & & $X$ \\
\hline Concursos/premiações & & & $x$ & & & \\
\hline \multicolumn{7}{|l|}{ Oficinas } \\
\hline Blog/site da biblioteca & & & & & & $X$ \\
\hline
\end{tabular}

Fonte. Elaboração própria.

\subsubsection{Pessoal}

Em relação aos funcionários da biblioteca, observa-se as diferenças entre as bibliotecas dos colégios públicos e colégios privados. No que concerne ao nível de formação do responsável pela biblioteca, os três colégios particulares $\mathrm{C} 1, \mathrm{C} 2$ e C3 
têm bibliotecários. O responsável pelo colégio C4 tem formação técnica em biblioteconomia. Os responsáveis pelas bibliotecas dos colégios C5 e C6 são professores de matérias extintas. Os colégios $\mathrm{C} 1, \mathrm{C} 2, \mathrm{C} 3, \mathrm{C} 4$ e $\mathrm{C} 6$ têm pessoal para trabalhar nos dois turnos.

Tabela 4: Funcionários da biblioteca.

\begin{tabular}{|c|c|c|c|c|c|c|}
\hline \multicolumn{7}{|c|}{ FUNCIONÁRIOS DA BIBLIOTECA } \\
\hline & C1 & $\mathbf{C 2}$ & C3 & $\mathrm{C4}$ & C5 & $\mathrm{C6}$ \\
\hline $\begin{array}{l}\text { Carga horária diária do } \\
\text { responsável pela } \\
\text { biblioteca }\end{array}$ & $8 \mathrm{~h}$ & $8 \mathrm{~h}$ & $4 \mathrm{~h}$ & $8 h$ & $8 \mathrm{~h}$ & $8 h$ \\
\hline $\begin{array}{l}\text { Nível de formação do } \\
\text { responsável pela } \\
\text { biblioteca }\end{array}$ & Adequado & Adequado & Adequado & & & \\
\hline $\begin{array}{l}\text { Número total de } \\
\text { funcionários/auxiliares }\end{array}$ & 2 & 3 & 3 & 5 & 1 & 4 \\
\hline
\end{tabular}

Fonte: Elaboração própria.

Após aplicação do formulário, foram realizadas duas questões relacionadas aos projetos. A primeira pergunta foi em relação às atividades realizadas que promovem as competências leitoras. Os bibliotecários dos colégios C2, C3, C4, C5 e C6 responderam que as atividades de promoção e animação da leitura são realizadas no ensino fundamental.

Os bibliotecários dos colégios C1, C2, C3 e C4 explicaram que os colégios atendem estudantes do ensino fundamental e ensino médio, mas que os projetos de leitura são desenvolvidos com estudantes de ensino fundamental. Os estudantes do ensino médio desenvolvem atividades de leitura com os professores de língua portuguesa. Dois colégios têm biblioteca em outra sede para atender aos alunos de ensino fundamental, com espaços adequados para a promoção da leitura. A porcentagem de alunos que culminou o Ensino Fundamental e continuam no mesmo colégio é de $90 \%$, considerado um número expressivo.

No caso do colégio $\mathrm{C} 1$, só há uma biblioteca geral para Ensino Fundamental e Ensino Médio e uma sala especial para fazer contação de histórias. O colégio C4 
tem clube de leitura e uma sala especial para a promoção da leitura em outro ambiente, ainda no espaço físico da escola. O projeto de leitura é coordenado pelo professor de língua portuguesa.

A segunda pergunta abordou a questão da parceria entre professores e biblioteca escolar. Houve consenso em reconhecer a importância do trabalho em parceria com os docentes, mas ressaltaram a falta de decisão política que motive a integração, pois os atores envolvidos não contam com apoio e reconhecimento por parte da direção. Os projetos que atualmente são desenvolvidos são feitos por iniciativa particular de algum dos professores amigos dos funcionários da biblioteca. Alguns projetos compartilhados pelos responsáveis das BEs são elencados a baixo.

- Viajando pelo mundo da leitura - desenvolver o prazer e o hábito de leitura.

- Programa de leitura interno - incentivar o gosto pela leitura nos militares do Colégio Militar de Brasília.

- Campanha de doação de livros e gibis para bibliotecas carentes.

- Distribuição de agendas culturais de Brasília.

- Concursos de marcadores de livros para a Biblioteca.

- Feira de livros.

- Manutenção e organização de uma sala de leitura.

- Intervalo musical.

- Momento de leitura.

- O canto da palavra.

- Feira literária.

- Gincana pedagógica.

- CEAN no Verde.

- Simulois - trabalha áreas temáticas e temas atuais.

\subsection{Resultado dos questionários}

O questionário foi aplicado aos professores que desenvolveram projetos de leitura. $O$ objetivo foi verificar as questões: 
- Relação entre o docente e a BE nos projetos de leitura (questões 3, 4, 5, 8, 9 e 10);

- Competências leitoras e estratégias de leitura usadas na promoção da leitura (questões 6, 7 e 10);

- Percepção sobre a contribuição da BE para os resultados do Enem (questão $11)$

As duas primeiras questões do questionário objetivaram identificar o gênero e a área de atuação dos professores pesquisados. As respostas foram apresentadas no tópico 4.2.1.

\subsubsection{Categoria: relação entre o docente e a BE nos projetos de leitura}

As questões 3, 4, 5, 8, 9 e 10 do questionário tiveram o objetivo de identificar as experiências de trabalho das BEs com os professores no desenvolvimento de projetos de leitura. A questão 10 contemplou as duas primeiras categorias, sendo apresentada na segunda categoria. Considera-se importante conhecer a concepção que os professores têm a respeito da BE para compreender como se desenvolvem as experiências de trabalho em parceria.

\section{Questão 3 - Características da concepção de BE dos professores pesquisados}

A questão três abordou a concepção que os professores tem da biblioteca escolar. De acordo com o gráfico 03 , dos pesquisados $55 \%$ têm a concepção da $B E$ como espaço de aprendizagem, pesquisa, leitura, eventos culturais. Em seguida, $25 \%$ dos professores a veem como espaço de consulta de livros e documentos e, finalmente, um percentual de $20 \%$ a veem como espaço de promoção da leitura. Nenhum dos entrevistados apresentou como resposta a alternativa $D$, vendo-a como um espaço para guardar informação. 
Gráfico 3 - Concepção de BE dos professores

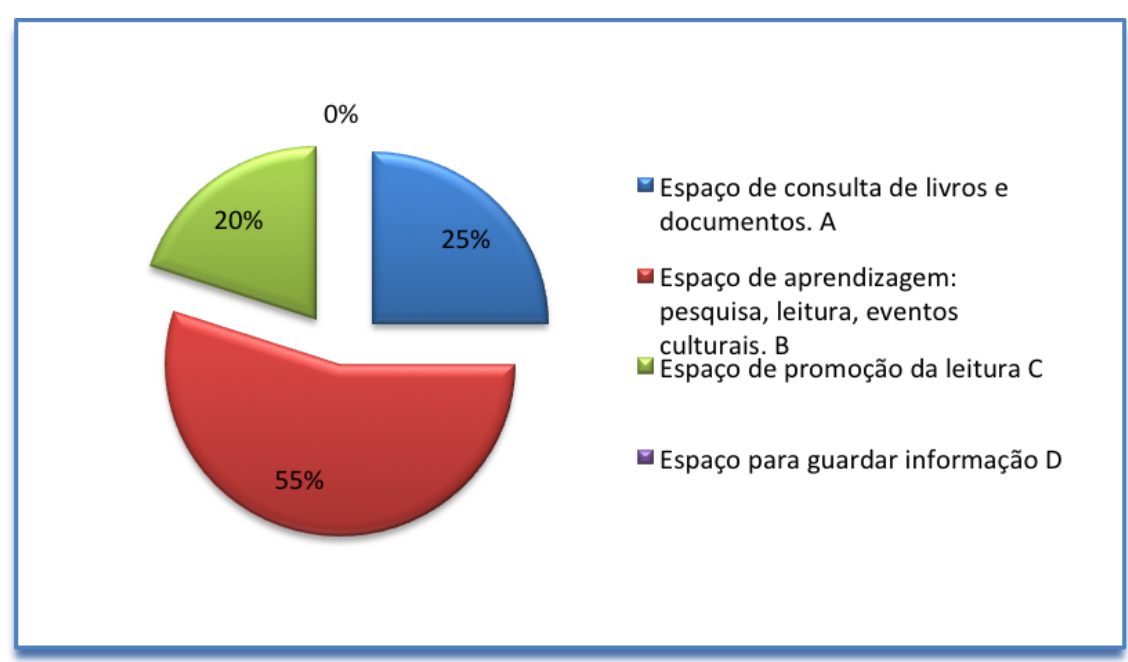

Fonte: Elaboração própria.

\section{Questão 4 - Planejamento das atividades de leitura na disciplina em que atua}

A questão quatro identificou o planejamento das atividades de leitura pelos docentes. Os resultados mostram que das quatro alternativas apresentadas em relação às atividades planejadas, os docentes escolheram apenas duas alternativas. Observa-se que $72 \%$ dos docentes planejam as atividades de leitura para serem aplicadas separadamente na sala de aula, $28 \%$ dos docentes planejam as atividades de leitura, utilizando informação da biblioteca. Não há planejamento de atividades em parceria com o bibliotecário, tampouco realização das atividades de leitura na BE.

Gráfico 4 - Planejamento das atividades de leitura.

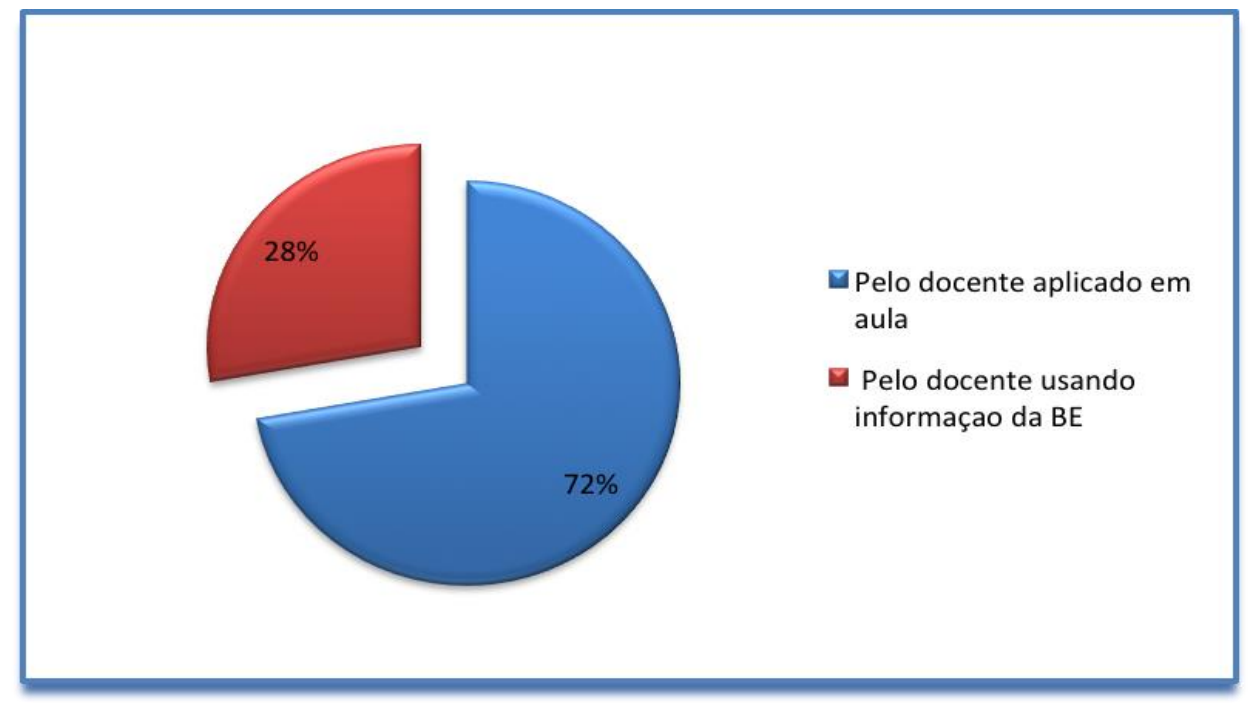

Fonte: Elaboração própria. 


\section{Questão 5 - Materiais de consulta da BE}

A questão cinco identificou o tipo de material indicado pelo professor para os estudantes usarem na biblioteca. Os livros de histórias (literatura) aparecem como os mais recomendados pelos professores, com 34\% das indicações e com uma frequência de uso mensal. Em segundo lugar, aparecem as revistas e jornais, recomendados por $22 \%$ dos professores, mas com frequência semanal. Outros $22 \%$ dos professores citaram os materiais de referência, de uso mensal, e os livros técnicos de uso semestral. Materiais multimídias (CD, DVD, Vídeo, CD-ROM) são poucos consultados nas BEs. Os dados são apresentados no gráfico 5.

Gráfico 5: Materiais de consulta da BE.

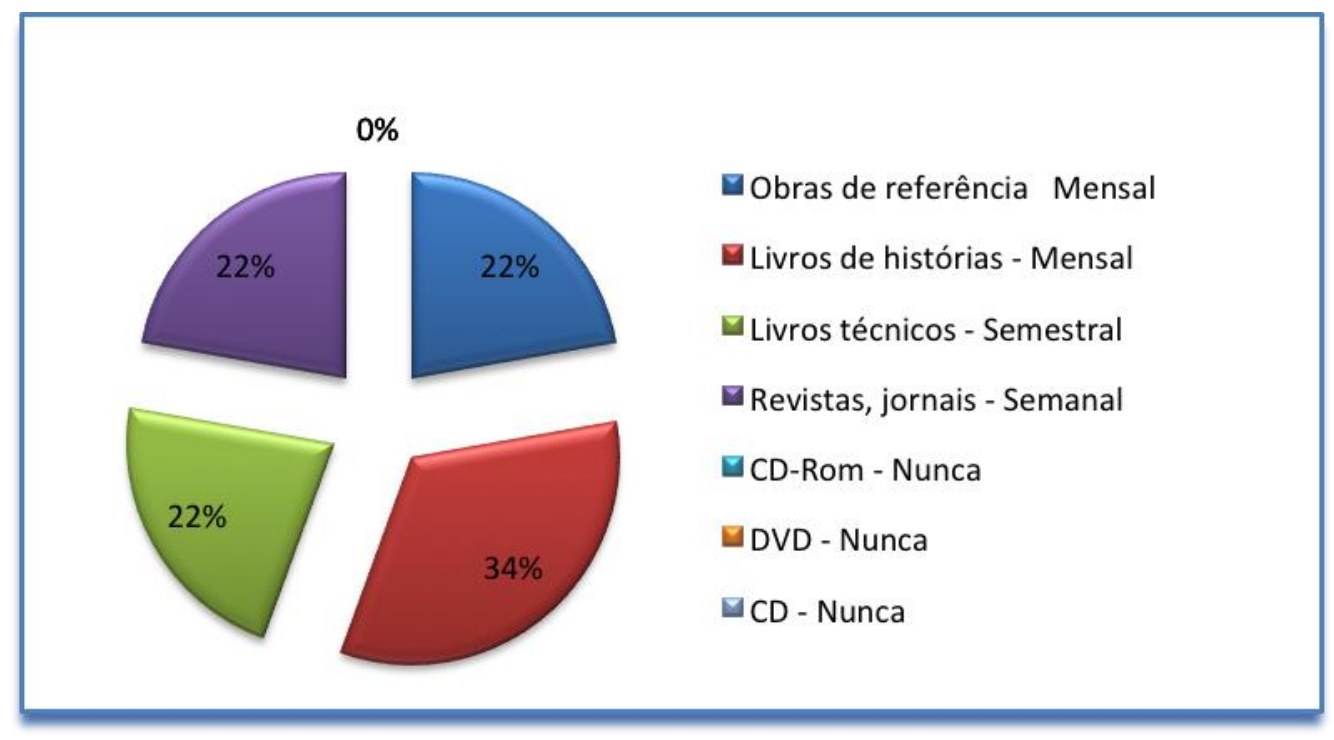

Fonte: Elaboração própria.

\section{Questão 8 - Parcerias e frequência entre a BE e os professores}

A questão oito identificou as parcerias e a frequência em que ocorrem as atividades de leitura entre professores e a BE. Os dados mostram que as atividades mais realizadas mensalmente são os projetos de pesquisa com $33 \%$ das respostas, seguido da seleção de matérias para a biblioteca, férias e eventos da escola. Os dados são apresentados no gráfico 6 . 
Gráfico 6 - Parcerias e frequência entre a BE e os professores.

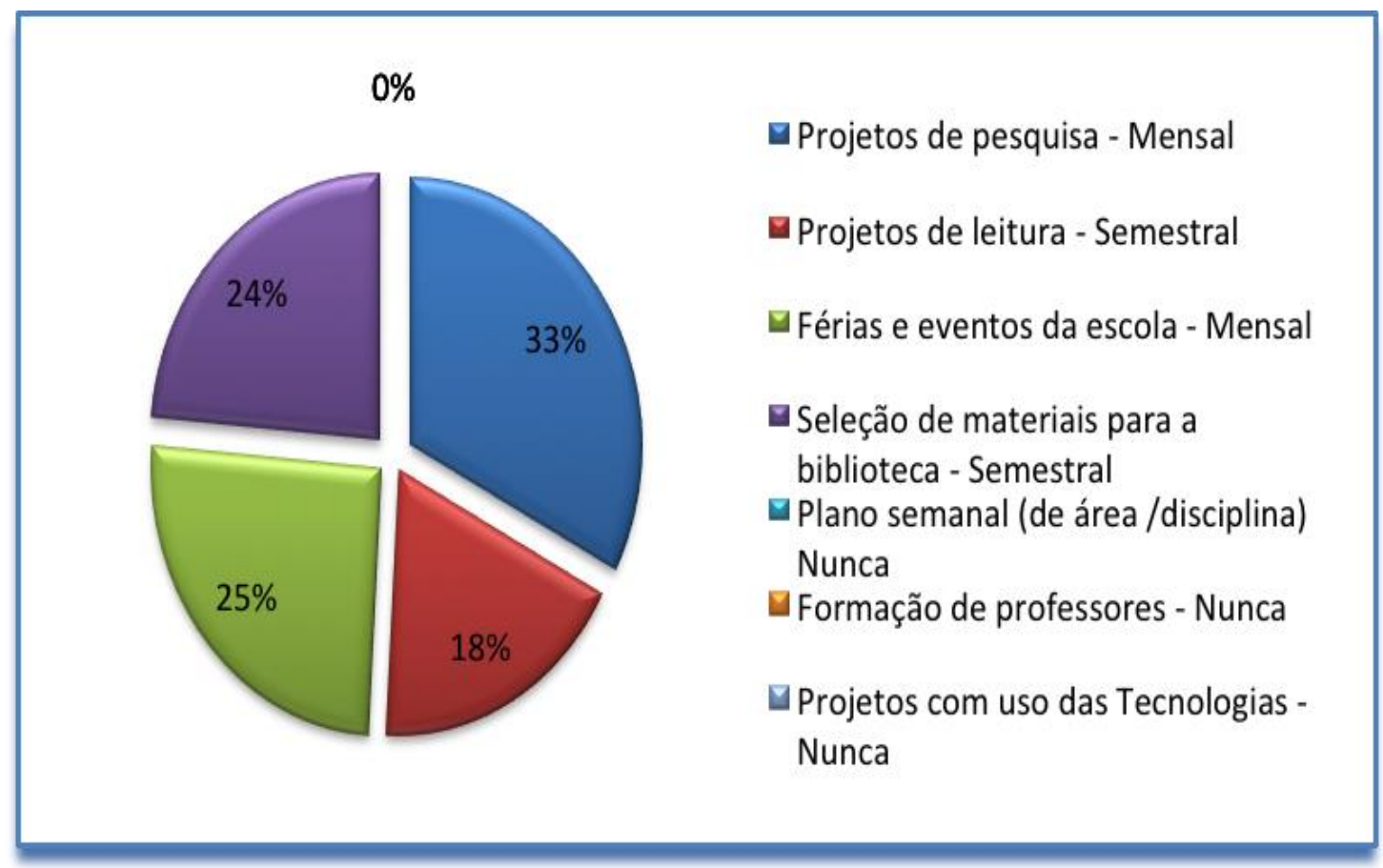

Fonte: Elaboração própria.

\subsubsection{Competências leitoras e estratégias de leitura usadas na promoção da leitura}

Essa categoria abrange as questões 6, 7 e 10 do questionário, as quais se relacionam com as competências e estratégias de leitura.

\section{Questão 6 - Estratégias leitoras mais utilizadas pelos professores}

A questão seis objetivou levantar as cinco estratégias de leitura mais utilizadas pelos professores em sala de aula de acordo os três espaços de tempo: "Antes da leitura", "Durante a leitura" e "Depois da leitura". Os dados mostram que 95\% disseram usar a estratégia de formulação de hipóteses antes da leitura. Outros $90 \%$ solicitam resumos após a leitura, e $85 \%$ releem com o auxílio de perguntas explícitas e inferenciais. Por fim, $75 \%$ relatam ativar os conhecimentos prévios (quanto se sabe sobre o texto), e $65 \%$ utilizam perguntas literais. 
Gráfico 7 - Estratégias de leitura mais utilizadas na promoção da leitura.

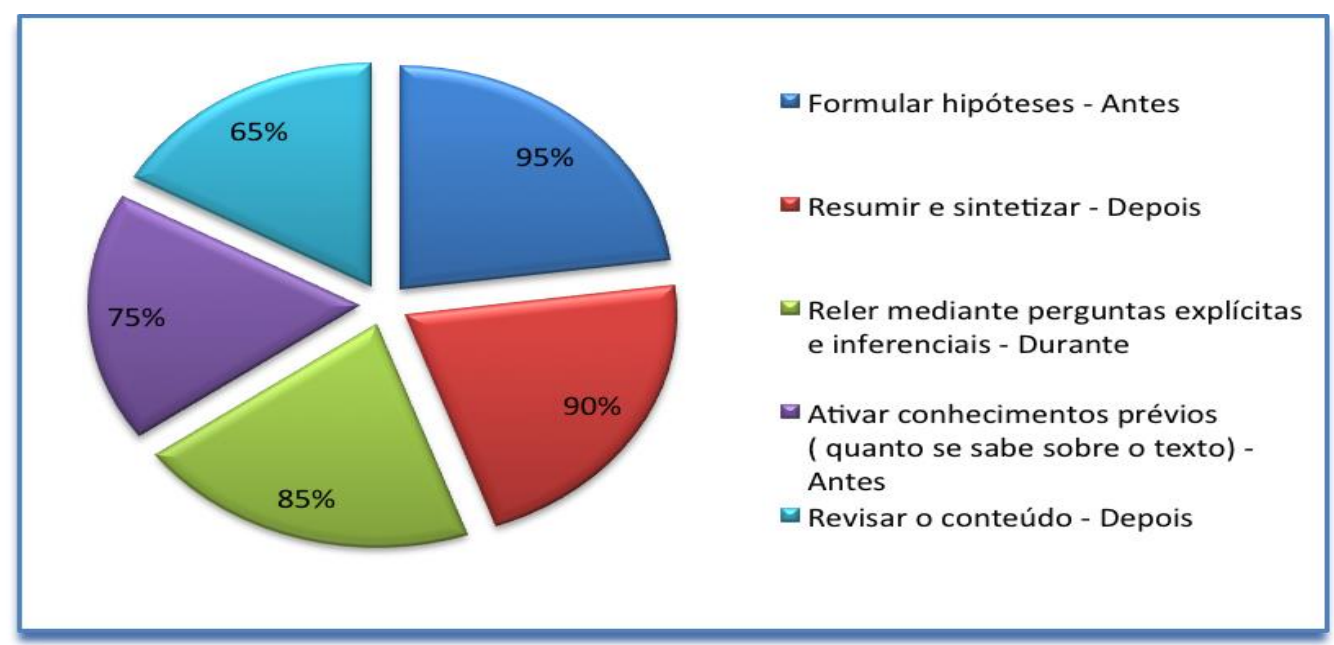

Fonte: Elaboração própria.

\section{Questão 7 - Promoção de práticas de leitura em sala de aula}

A pergunta sete tratou da frequência com que os professores promovem práticas de leitura em sala de aula. A pergunta foi formulada de acordo com a proposta de Geraldi (1997) sobre a prática de leitura na escola e como ela relacionase à construção de sentido do texto por parte do leitor. As respostas mostram que os tipos de leitura mais usados são a leitura-busca de informações e a leitura-fruição do texto, ambas com $90 \%$ de respostas e com frequência de uso semanal. Os outros dois tipos de textos têm porcentagem muito baixa e são desenvolvidos semestral e anualmente, respectivamente.

Gráfico 8 - Tipos de leitura mais utilizados e frequência de uso.

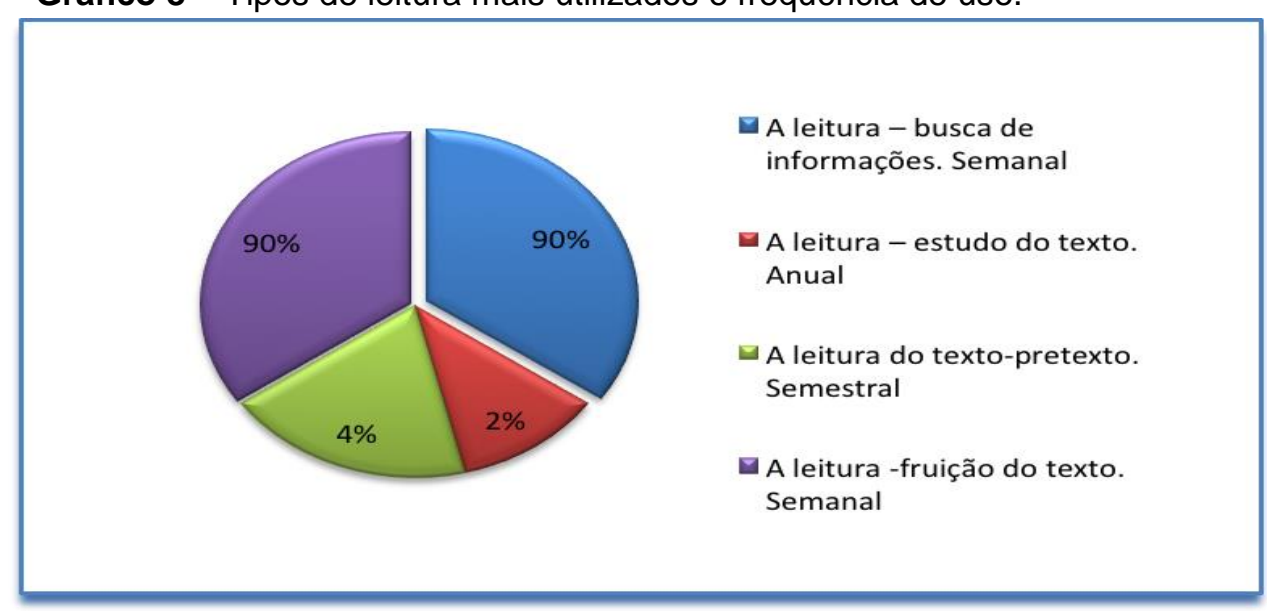

Fonte: Elaboração própria. 


\section{Questão 10 - Frequência de atividades desenvolvidas na biblioteca}

A questão dez relaciona-se à frequência de atividades desenvolvidas na $B E$. Os dados mostram que "realizar pesquisa com os estudantes" é a atividade mais frequentemente desenvolvida na biblioteca, com periodicidade semestral. A essa atividade, segue-se a participação em "atividades promovidas pela BE", de periodicidade semestral também. Empréstimos de livros é uma atividade que se realiza quinzenalmente. Os professores que desenvolvem projetos de leitura nunca vão com os estudantes à biblioteca escolar para acessar à internet, como se observa no gráfico a seguir. Os dados são apresentados nos gráficos 9A e 9B.

Gráfico 9A - Atividades desenvolvidas na BE.

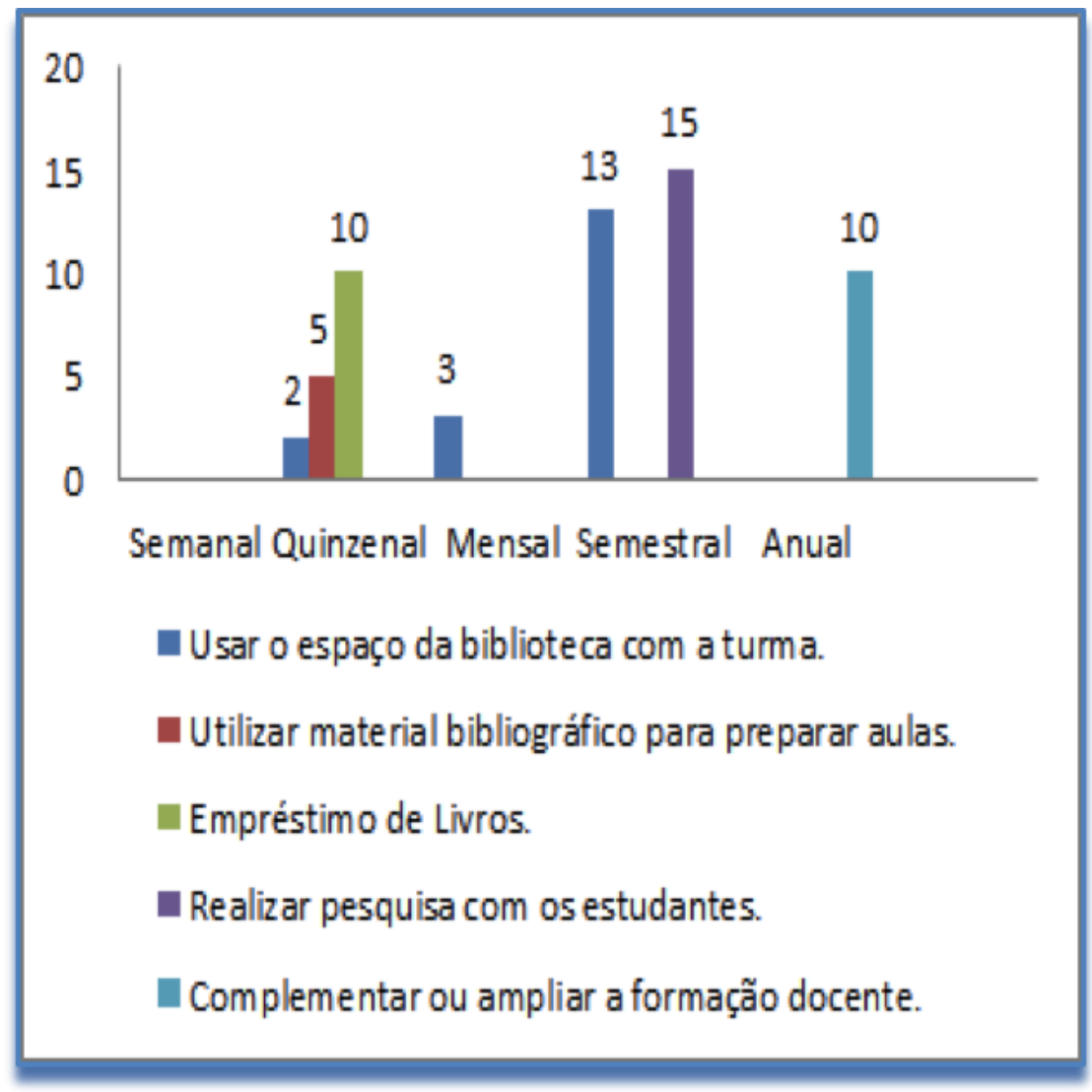

Fonte: Elaboração própria. 
Gráfico 9B - Atividades desenvolvidas na BE.

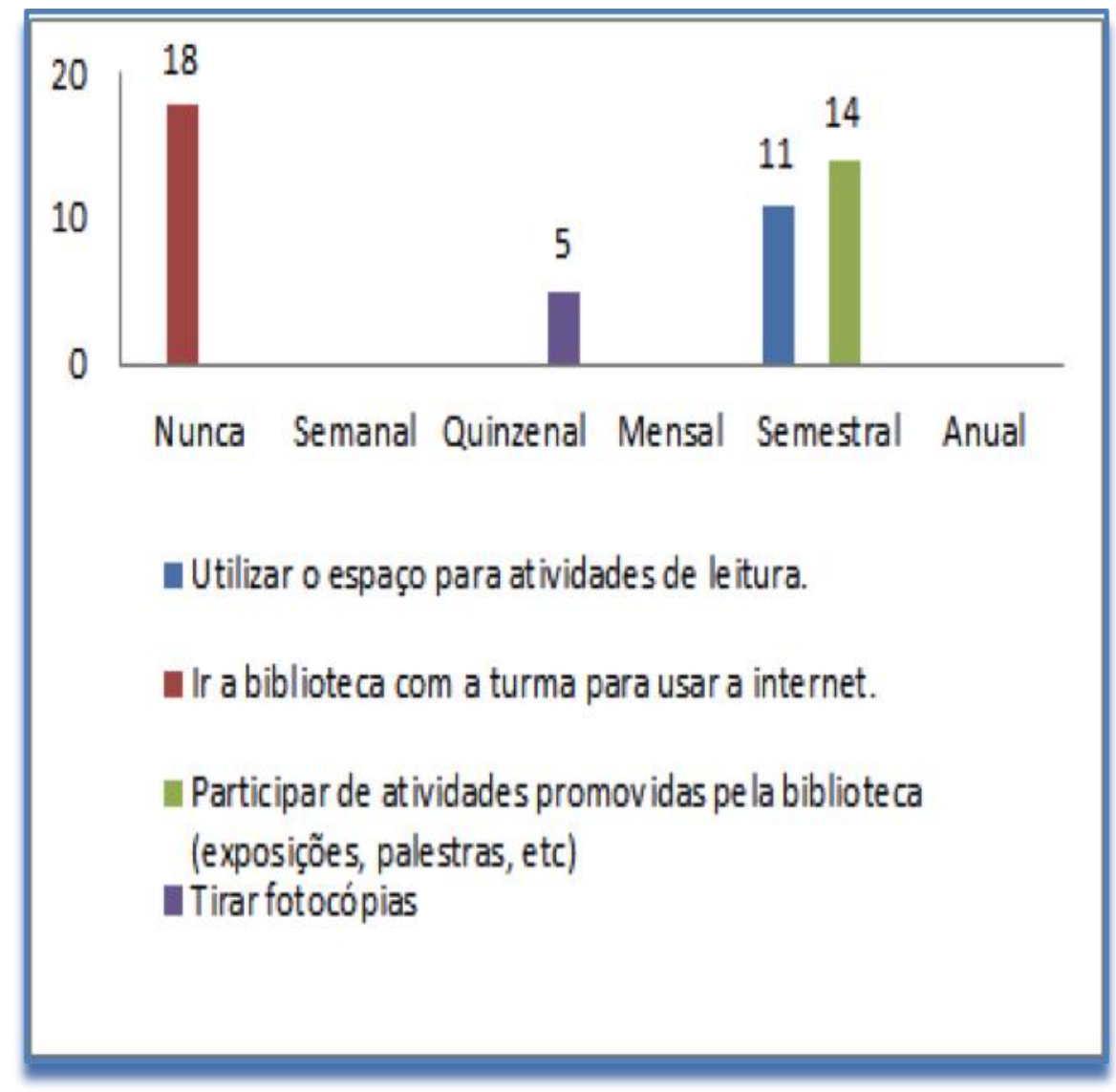

Fonte: Elaboração própria.

\subsubsection{Percepção sobre a contribuição da BE para os resultados do Enem}

A categoria percepção dos professores sobre a contribuição da BE para os resultados do Enem abrange somente a questão 11. Os dados mostram que os professores percebem a BE como uma instituição que contribui positivamente para os resultados de Enem. Os professores avaliaram positivamente o horário de atendimento e a presença de funcionários competentes no atendimento aos estudantes. Em seguida, os professores avaliaram também positivamente o acervo atualizado, os projetos de leitura e pesquisa, e, por fim, o trabalho integrado da biblioteca com o currículo. Os dados são apresentados no gráfico 10. 
Gráfico10 - BE contribuição no Enem.

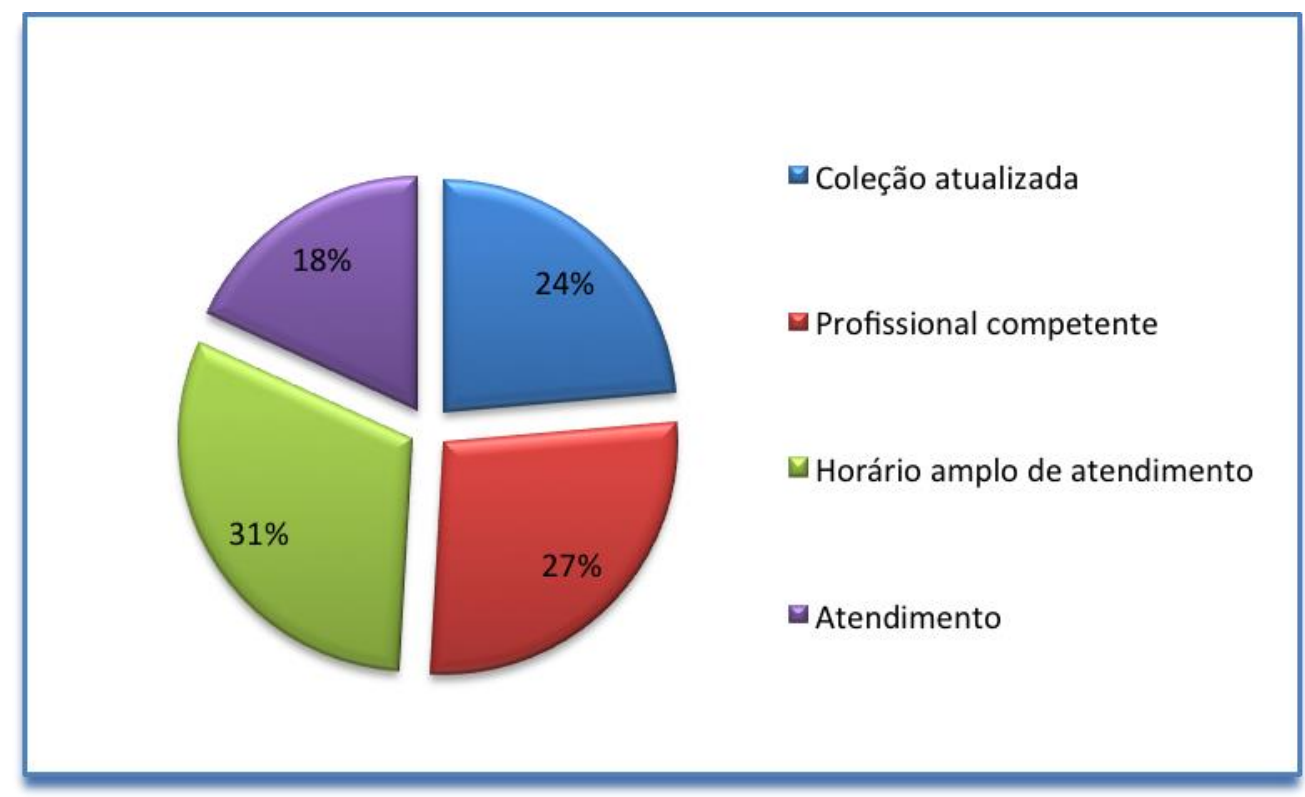

Fonte: Elaboração própria.

Cabe destacar que o questionário permitiu conhecer como os professores percebem a $\mathrm{BE}$, quais são os trabalhos que realizam em parceria e como desenvolvem as atividades de leitura, estratégias de leitura, dentre outras questões. 


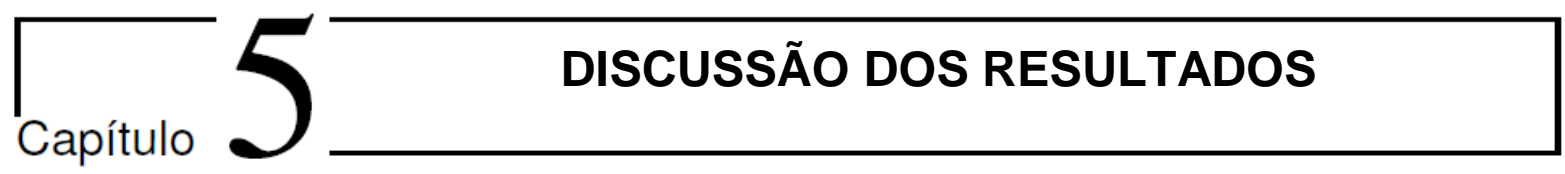

No presente capítulo, com base na análise dos resultados da pesquisa e considerando os fundamentos teóricos, apresentados no capítulo II, discutem-se os resultados da pesquisa a partir dos objetivos específicos, quais sejam: descrição da proposta pedagógica e das estruturas das escolas pesquisadas; descrição da estrutura, dos produtos e os serviços oferecidos pela biblioteca escolar das escolas pesquisadas; identificação dos projetos de leitura e a contribuição da biblioteca escolar para a formação de competências leitoras, e, por fim, identificação da relação entre o docente e o bibliotecário nos projetos de leitura.

O objetivo principal dessa pesquisa é analisar a configuração da biblioteca escolar nas escolas que obtiveram os melhores desempenhos na avaliação do Enem, considerando especificamente os projetos de leitura.

\subsection{Estrutura e proposta pedagógica dos colégios pesquisados}

A estrutura e a proposta pedagógica são importantes elementos para dar suporte à integração pedagógica da BE. São necessárias não somente condições materiais e políticas, mas, sobretudo, condições pedagógicas, as quais também são políticas. Enfatiza-se a necessidade de garantir que a formulação das políticas educacionais e das condições estruturais estejam presentes nas instituições escolares para que as bibliotecas escolares sejam concebidas como Centro de Recursos de Aprendizagem.

A concepção pedagógica dos colégios pesquisados foi analisada, considerando a leitura e a configuração da biblioteca escolar. Os documentos das escolas mostram que os projetos políticos-pedagógicos estão desenhados de acordo com a abordagem Construtivista com enfoque social, em que o estudante é protagonista do próprio processo de aprendizagem, a partir de uma concepção pessoal e coletiva na aquisição de novos conhecimentos (HERNÁNDEZ, 2007). O construtivismo social baseia-se na aprendizagem cooperativa, em que uma de suas características é o trabalho em pequenos grupos, que incentiva os estudantes a aprenderem com os pares e com os professores. 
Os dados mostram que as escolas, em geral, possuem boa infraestrutura, espaços adequados para estudar, espaços para lazer, segurança, limpeza adequada. Contudo, há diferença no que tange ao acesso às tecnologias da informação e comunicação, isto é, os colégios particulares, diferentemente dos públicos, contam com tecnologia de última geração.Apesar de inúmeras dificuldades em relação à infraestrutura, materiais e capacitação, percebeu-se que os colégios públicos buscam formas de programar atividades de aprendizagem por meio de projetos interdisciplinares que estimulam o pensamento crítico dos estudantes. Projetos que poderiam ter resultados diferenciados com uma biblioteca mais atuante.

No documento "Por las bibliotecas escolares de Ibero América" (CERLAC; UNESCO, 2007, p. 30-34), são apresentados elementos de integração na prática da $\mathrm{BE}$. As bibliotecas escolares devem se integrar à politica educativa da escola e do país. Além disso, ressalta-se a importância da concepção pedagógica da escola, conforme menciona Gasque (2013), para o êxito da nova concepção de BE. Isso porque, de acordo com a autora, escolas com currículos flexíveis, que incentivam atividades de resolução de problemas requerem uma biblioteca mais dinâmica e integrada ao projeto educacional.

\subsection{Estrutura, produtos e os serviços oferecidos pela biblioteca escolar das escolas pesquisadas}

Os padrões da avaliação das bibliotecas escolares da GEBE-UFMG permitiram criar um panorama completo da realidade das bibliotecas escolares pesquisadas em relação aos itens: infraestrutura, serviços, coleção, tecnologia e pessoal, bem como forneceram critérios para avaliação desses itens.

Em relação à estrutura, as bibliotecas escolares situadas no nível exemplar são as que apresentam assentos suficientes para acomodar simultaneamente uma classe inteira, usuários avulsos e grupos de alunos; um balcão de atendimento; e ambiente específico para atividades técnicas, com uma mesa, uma cadeira e um computador com acesso à internet. Destaca-se que foi necessário acrescentar o nível zero para as bibliotecas que não cumpriram os requisitos do padrão básico. 
Com base nos dados registrados nos formulários, as bibliotecas pesquisadas foram avaliadas como:

\begin{tabular}{|c|l|l|c|c|c|}
\hline C1 & \multicolumn{1}{|c|}{ C2 } & C3 & C4 & C5 & C6 \\
\hline Nível básico & $\begin{array}{l}\text { Nível } \\
\text { básico }\end{array}$ & $\begin{array}{l}\text { Nível } \\
\text { básico }\end{array}$ & Nível exemplar & Nível Zero & Nível Zero \\
\hline
\end{tabular}

De acordo as respostas dos formulários, só a biblioteca do colégio C4 cumpre todos os critérios. As bibliotecas dos colégios C2 e C3 encontram-se no nível básico, pois têm assentos suficientes para acomodar simultaneamente uma classe inteira; um balcão de atendimento, uma mesa, uma cadeira e um computador com acesso à internet. Os colégios $\mathrm{C} 1, \mathrm{C} 5, \mathrm{C} 6$ não cumprem com nenhum dos critérios propostos pelos padrões. As bibliotecas dos colégios C5 e C6 não têm computadores, nem acesso à internet. A biblioteca do colégio $\mathrm{C} 1$ tem computador, mas não tem espaço para acomodar uma classe inteira.

Em suma, somente uma biblioteca possui o nível exemplar e três não se enquadram nem no nível básico. A estrutura básica é importante para que as bibliotecas tenham condições de oferecer bons serviços e produtos. Sobre isso, destaca-se:

O conceito de biblioteca escolar atuante como Centro de Recursos de Aprendizagem é fundamental para se ter uma abordagem sistêmica e integrada à comunidade educacional. Nessa abordagem, a estrutura (arquitetura, lay-out, mobiliários, recursos e produtos) constitui-se elemento fundamental (GASQUE, 2013, p. 8).

Em relação aos computadores com acesso à internet para uso de professores e estudantes, foram encontrados os seguintes dados: as bibliotecas dos colégios C2,C3 e C4 apresentam computadores conectados à internet para a busca de informação, os colégios C3 e C4 não forneceram dados sobre a relação computador $\mathrm{X}$ alunos. As bibliotecas dos colégios, C1,C5 e C6 não possuem computador para uso dos estudantes. Diante disso, os últimos colégios mencionados, de acordo os padrões da GEBE, não se encontram em nenhum nível, por isso foram avaliados como nível zero. Os colégios C2, C3 e C4 encontram-se no nível básico, compreendidos como aqueles que têm "pelo menos um computador ligado à internet 
para uso exclusivo de professores e estudantes em atividades de ensino/ aprendizagem".

\begin{tabular}{|l|l|l|l|l|l|}
\hline C1 & C2 & C3 & C4 & C5 & C6 \\
\hline Nível zero & Nível básico & $\begin{array}{l}\text { Nível } \\
\text { básico }\end{array}$ & Nível básico & Nível zero & Nível zero \\
\hline
\end{tabular}

Sobre isso, destaca-se que na sociedade da aprendizagem ter acesso às informações representa o primeiro passo para a aprendizagem. Nessa sociedade, as tecnologias da informação e comunicação constituem-se um dos pilares que estão no cerne das transformações contemporâneas (GASQUE, 2012). As bibliotecas, nesse contexto, precisam contar com os recursos necessários para ampliar o conhecimento dos membros da sociedade. O documento Diretrizes para Bibliotecas Escolares menciona que as bibliotecas escolares devem incluir no orçamento e planejamento recursos eletrônicos como acesso à Internet, bases de dados e software educativo (IFLA/UNESCO, 2002). Para Kuhthau (1999), os computadores conectados à internet permitem ampliar o acesso à informação para uma vasta coleção disponível na rede, além disso, ressalta que a aprendizagem desses recursos pode ser potencializada pela mediação dos bibliotecários em parceria com os professores.

No que concerne à organização do acervo, de acordo com os padrões da GEBE-UFMG, as bibliotecas no nível básico devem incluir pelo menos os livros do acervo, de forma a permitir a recuperação por autor, título e assunto. No nível exemplar, a BE deve possibilitar o acesso remoto a todos os itens do acervo, bem como a recuperação por outros pontos de acesso. As bibliotecas dos colégios $\mathrm{C} 5 \mathrm{e}$ C6 não possuem os requisitos mínimos para o nível básico, pois não possuem computadores, nem base de dados que permitam o acesso rápido à informação. As bibliotecas dos colégios $\mathrm{C} 1, \mathrm{C} 2, \mathrm{C} 3$ e C4 contam com catálogo informatizado com acesso remoto ao acervo, portanto foram avaliadas como exemplares nesse critério.

\begin{tabular}{|l|l|l|l|l|l|}
\hline C1 & C2 & C3 & C4 & C5 & C6 \\
\hline Nível exemplar & $\begin{array}{l}\text { Nível } \\
\text { exemplar }\end{array}$ & $\begin{array}{l}\text { Nível } \\
\text { exemplar }\end{array}$ & $\begin{array}{l}\text { Nível } \\
\text { exemplar }\end{array}$ & Nível Zero & Nível zero \\
\hline
\end{tabular}

Em relação ao acervo, os padrões da GEBE-UFMG consideram que as bibliotecas no nível exemplar são aquelas que possuem a partir de quatro títulos por 
estudante. No nível básico, requer-se pelo menos um livro por estudante. Os padrões destacam para os dois níveis que além de livros, a biblioteca escolar deve contar com revistas e outros materiais não impressos, tais como: documentos sonoros, visuais e digitais. As seis bibliotecas pesquisadas nesse quesito possuem nível exemplar. Os dados podem ser observados a seguir:

\begin{tabular}{|l|l|l|l|l|l|}
\hline C1 & C2 & C3 & C4 & C5 & C6 \\
\hline $\begin{array}{l}\text { Nível } \\
\text { exemplar }\end{array}$ & $\begin{array}{l}\text { Nível } \\
\text { exemplar }\end{array}$ & $\begin{array}{l}\text { Nível } \\
\text { exemplar }\end{array}$ & $\begin{array}{l}\text { Nível } \\
\text { exemplar }\end{array}$ & $\begin{array}{l}\text { Nível } \\
\text { exemplar }\end{array}$ & $\begin{array}{l}\text { Nível } \\
\text { exemplar }\end{array}$ \\
\hline
\end{tabular}

Carvalho (1972) argumenta que a biblioteca escolar tem como objetivos específicos facilitar o ensino, fornecendo material bibliográfico adequado tanto para o uso dos professores e dos estudantes. Destaca-se que o acervo foi avaliado quantitativamente e não qualitativamente. De acordo com Hopkins (1999), considera-se o acervo da biblioteca fundamental para o desenvolvimento do ensinoaprendizagem. A plena utilização da biblioteca escolar vincula-se em grande parte do acesso às informações atualizadas e precisas, de boa qualidade, e em quantidade suficiente, que deem apoio ao currículo. Para tanto, requer desenvolver programas de formação profissional para que os professores possam colaborar na seleção de materiais.

As bibliotecas escolares foram avaliadas em relação aos serviços, considerando os padrões da GEBE-UFMG. Para o nível básico, as BEs precisam oferecer consulta no local, empréstimo domiciliar, atividades de incentivo à leitura $\mathrm{e}$ orientação à pesquisa. Para o nível exemplar, devem oferecer consulta no local, empréstimo domiciliar, atividades de incentivo à leitura e orientação à pesquisa, além de serviço de divulgação de novas aquisições, exposições e serviços específicos para os professores, tais como levantamento bibliográfico e boletim de alerta. Considerando os referidos padrões, as seis escolas pesquisadas foram avaliadas no nível básico.

\begin{tabular}{|l|l|l|l|l|l|}
\hline C6 & C5 & C4 & C3 & C2 & C1 \\
\hline $\begin{array}{l}\text { Nível } \\
\text { básico }\end{array}$ & Nível básico & Nível básico & $\begin{array}{l}\text { Nível } \\
\text { básico }\end{array}$ & $\begin{array}{l}\text { Nível } \\
\text { básico }\end{array}$ & $\begin{array}{l}\text { Nível } \\
\text { básico }\end{array}$ \\
\hline
\end{tabular}


Com relação aos serviços, pode-se observar duas questões importantes. Em primeiro lugar, as BEs dos colégios privados têm mais investimentos em infraestrutura, equipes e tecnologia, fato que se reflete nos serviços e produtos oferecidos por elas. Behr, Moro e Estabel (2008) explicitam sobre a importância da satisfação dos usuários a partir dos serviços de qualidade e eficiência apresentada pela biblioteca escolar. Para tanto, sugerem que os serviços prestados constantemente precisam ser avaliados para conhecer a necessidade dos usuários.

Por fim, as bibliotecas foram avaliadas em relação aos recursos humanos de acordo com os padrões da UFMG-GEBE. Pelo padrão básico, as bibliotecas devem contar com um bibliotecário supervisor por um grupo de bibliotecas, além de pessoal auxiliar em cada uma das bibliotecas, em cada turno. No nível exemplar, requer-se um bibliotecário responsável pela biblioteca e pessoal auxiliar em cada turno, em consonância, com a quantidade de estudantes. Os dados mostram que as bibliotecas $\mathrm{C} 1, \mathrm{C} 2$ e $\mathrm{C} 4$ foram avaliadas como exemplares. As bibliotecas dos colégios C3, C5 e C6 não obtiverem os requisitos mínimos, por isso, foram avaliadas no nível zero.

\begin{tabular}{|l|l|l|l|l|l|}
\hline \multicolumn{1}{|c|}{ C1 } & \multicolumn{1}{c|}{ C2 } & \multicolumn{1}{c|}{ C3 } & \multicolumn{1}{c|}{ C4 } & \multicolumn{1}{c|}{ C5 } & C6 \\
\hline $\begin{array}{l}\text { Nivel } \\
\text { exemplar }\end{array}$ & $\begin{array}{l}\text { Nível } \\
\text { exemplar }\end{array}$ & $\begin{array}{l}\text { Nível } \\
\text { básico }\end{array}$ & $\begin{array}{l}\text { Nível } \\
\text { exemplar }\end{array}$ & Nível zero & $\begin{array}{l}\text { Nível } \\
\text { zero }\end{array}$ \\
\hline
\end{tabular}

Considerando a importância das BEs contarem com profissionais com formação especializada, a Lei da Biblioteca Escolar - Lei 12244/10, de 24 de maio de 2010, dispõe que as instituições de ensino públicas e privadas de todos os sistemas de ensino do País devem contar com bibliotecas escolares com a presença de um bibliotecário. A lei deve ser cumprida efetivamente até 24 de maio de 2020. Para Gasque (2012), o fato de as bibliotecas contarem com um bom acervo, por si só, não as transformam em Centro de Recursos de Aprendizagem. Para tanto, precisam ser espaços de incentivo à pesquisa, à leitura e à cultura. Isso requer a presença de um bibliotecário com boa formação e atitude para mudanças. A autora argumenta ainda sobre a necessidade do envolvimento da comunidade escolar. 


\subsection{Projetos de leitura e a contribuição da biblioteca escolar para a formação de competências leitoras}

Um dos objetivos específicos da pesquisa foi identificar os projetos de leitura das escolas pesquisadas e verificar a contribuição das bibliotecas escolares. A análise dos dados dos questionários, respondidos pelos professores, mostra que as bibliotecas pesquisadas não participavam ativamente dos planejamentos e do desenvolvimento das atividades de leitura. Vale ressaltar que as bibliotecas escolares devem cumprir papel essencial nesse processo, como menciona o documento "Por las bibliotecas escolares de Ibero América". De acordo com ele, a biblioteca escolar consiste de um espaço, por natureza, propício ao desenvolvimento das práticas de leitura e escrita, com possibilidade de dar suporte pedagógico e material para as várias áreas curriculares (CERLAC; UNESCO, 2007, p. 32).

Outro objetivo da pesquisa foi analisar a contribuição da biblioteca escolar para a formação de leitores. Verificou-se que os colégios pesquisados oferecem atividades de leitura sem muita interação com as bibliotecas. Mais da metade dos docentes planejam as atividades de leitura sozinhos. Essas atividades são, em geral, realizadas em sala de aula. Por sua vez, as poucas bibliotecas que oferecem tarefas de leitura, centram-se nos estudantes do ensino fundamental e desenvolvem, na verdade, trabalho de animação da leitura. Isso significa que incentivam o gosto pela leitura, o uso do livro e da biblioteca, mas não desenvolvem competências leitoras.

É importante salientar que Cuevas (2007) e Naranjo (2005) diferenciam os termos animação da leitura e promoção da leitura. Animação da leitura refere-se à atividade que motiva os leitores, que possibilita a recreação mediante leitura de textos selecionados. Por sua vez, a promoção da leitura transcende a animação do livro e o uso da biblioteca, centrando-se no ensino de estratégias de leitura e fazendo uso da leitura compartilhada, por exemplo, para fortalecer as competências leitoras dos estudantes.

Outra questão importante observada nos dados dos questionários refere-se às atividades de leitura realizadas no ensino médio. Tais atividades são realizadas em sala de aula e estão mais orientadas para a pesquisa, projetos de apoio social e práticas para os vestibulares. Muito se tem criticado sobre a questão da formação do 
ensino médio voltada somente para o vestibular. Santos (2011) explica que há anos o vestibular tem sido a referência do Ensino Médio, porém agora, o Enem começa a tomar outra dimensão, sendo responsável por estruturar o currículo desse nível de ensino. Dessa forma, o governo prepara a abolição do vestibular e toma o Enem como o natural sucessor. O autor argumenta que o MEC pretende resolver o problema de parte do Ensino Médio, principalmente nas escolas particulares, acusadas de atender às exigências dos vestibulares, por meio de conteúdos extensos e dissociados da realidade.

Quando questionado sobre o uso de estratégias leitoras que os professores utilizam em sala de aula, os resultados mostram que são aplicadas as estratégias básicas. Cantalice (2004) aborda o importante papel exercido pelo professor ao propor modelos técnicos e procedimentos que proporcionem a compreensão da leitura. Ela explica que dentre as estratégias de leitura está centrar a atenção dos estudantes nas idéias principais; questionar os estudantes sobre o grau de compreensão da leitura, relacionar o conhecimento prévio dos alunos com nova informação; propiciar feedback para ajudar os estudantes a aplicarem técnicas e estratégias de estudo apropriadas; propiciar treinamento aos estudantes para usarem essas estratégias e técnicas de maneira mais efetiva; utilizar reforços positivos verbais e de escrita para estudantes com baixa compreensão; ajudar os estudantes a identificarem as contradições na compreensão do texto, bem como propiciar contato com vários tipos de textos em sala de aula. Ressalta-se que essas estratégias devem ser usadas desde as séries iniciais do ensino fundamental. Mais ainda, a autora sinaliza a importância do psicólogo escolar para avaliar e assessorar os professores nessa atividade de ensino.

No referente aos tipos de práticas de leitura em sala de aula e como se relacionam à construção de sentido do texto por parte do leitor, os resultados mostram que os tipos de leituras mais usados foram a leitura busca de informações e a leitura por fruição. No primeiro caso, o leitor extrai informações dos textos para responder as questões. No segundo, o objetivo é possibilitar o prazer de ler. Contudo, destaca-se que o "prazer de ler" é voltado para a leitura de livros de literatura para o vestibular. Antunes (2012) observou que esse tipo de prática de leitura em aula era a mais comum. A leitura era basicamente utilizada para a realização de tarefas e as práticas eram voltadas para a compreensão das ideias do 
autor do texto. Desse modo, não era proporcionado à maioria dos estudantes a oportunidade do desenvolvimento do pensamento crítico.

Há desafios a superar no estímulo ao gosto pela leitura por meio das obras que serão objetos de avaliação no vestibular e Enem. Cesila (2009) questiona como o professor pode superar a incumbência de despertar o gosto pelos livros e, ao mesmo tempo, cumprir o conteúdo programático pré-estabelecido para cada ano do ensino médio. Acrescenta que a lista de autores, escolas literárias e detalhes históricos, conteúdos de aprendizagem, em geral, estão distantes da realidade dos estudantes e podem gerar efeito contrário. A autora apresenta alternativas para tornar o ensino de leitura mais prazeroso. Dentre elas, a leitura em conjunto com os estudantes com o objetivo de "traduzir" as palavras mais difíceis, fazer uso de imagens, por exemplo, charges, tirinhas ou histórias em quadrinhos como recursos auxiliares, ressaltando que isso não significa deixar de colocar o estudante em contato com a obra original.

As propostas curriculares permitem também conhecer a configuração da leitura. Nos colégios particulares, observa-se que a proposta curricular, além de abranger as disciplinas tradicionais, incorporam outras que reforçam a aprendizagem da leitura. No Colégio Vértice, por exemplo, avaliado na quarta melhor posição do Brasil no ranking do Enem de 2013, o currículo tem uma disciplina denominada "Interpretação de texto". No colégio Galois, $2^{\circ}$ melhor do ranking do Enem 2013 do DF, há o curso de "Redação", que se desenvolve desde a Educação Básica até o Ensino Médio. Da Educação Básica ao Ensino Fundamental II, há a promoção de atividades de leitura. Contudo, essas atividades são desenvolvidas pelos professores de língua portuguesa sem integração com a biblioteca.

Uma experiência, relatada por Gasque (2013), que pode "inspirar" os colégios foi realizada pelo Colégio Marista de Brasília. Em geral, os primeiros projetos de fomento à leitura do colégio eram atividades episódicas ou projetos pessoais de alguns professores, por isso investiu-se em um projeto comum e sistematizado para formação do leitor, que consistiu de sete pontos: 
1) desenvolvimento de estratégias diversificadas de leitura e compreensão de diferentes gêneros textuais em todas as disciplinas do currículo;

2) graduação do trabalho com gêneros e textos, em Língua Portuguesa, nas diferentes séries;

3) estabelecimento de metas literárias ao longo dos anos

4) ampliação das habilidades (compreensão, rapidez) de leitura dos professores e estudantes;

5) expansão do vocabulário e melhoria da ortografia;

6) contato mais estreito com obras e autores diversificados da literatura infantil e,

7) ampliação do uso dos recursos e serviços do Centro de recursos de aprendizagem.

Adicionalmente, acrescenta-se aos sete pontos o monitoramento constante do processo, do trabalho dos professores e desempenho dos estudantes. Isso porque mesmo os melhores projetos podem ser deixados de lado na rotina corrida da vida escolar. Dessa forma, o projeto de leitura torna-se responsabilidade compartilhada pela comunidade educativa.

\subsection{Relação entre o docente e o bibliotecário nos projetos de leitura.}

A pesquisa investigou a relação entre docentes e os bibliotecários das escolas em relação aos projetos de leitura. Os dados mostram a existência de uma concepção abrangente da biblioteca escolar. Os docentes a veem como espaço de aprendizagem, pesquisa, leitura e eventos culturais. Apesar disso, verificou-se a ausência de trabalho integrado entre docentes e bibliotecários em relação aos projetos de leituras. As atividades que, em geral, são desenvolvidas em parceria entre BE e professores são os projetos de pesquisa e os eventos da escola, bem como a seleção de materiais para a biblioteca. Contudo, somente um terço dos professores usam o espaço e os recursos.

As hipóteses principais para explicar esses resultados são: a cultura tradicional do professor e da própria escola, bem como a grande quantidade de 
conteúdos do currículo que impede que sejam realizadas tarefas que requerem mais tempo. De acordo com Gasque e Costa (2003), tradicionalmente no Brasil, o livro didático ainda é a fonte de informação mais usada em sala de aula. As autoras explicam que essa forte vinculação com o livro didático ocorre devido à rotina e a forte tradição pedagógica a qual os professores estão submetidos. Nessa perspectiva, o livro didático atua como espinha dorsal de quase todos os componentes curriculares. Isso faz com que os professores não busquem outros materiais, consequentemente não veem necessidade de usar a biblioteca.

Ainda sobre a questão do uso das bibliotecas, o relatório de avaliação das bibliotecas escolares brasileiras (2013), promovido pelo Ministério da educação do Brasil (MEC), em parceria com a organização dos Estados Ibero-Americanos (OEI) e com a Agência Espanhola de Cooperação Internacional para o Desenvolvimento (Aecid) reconhece a necessidade de os professores desenvolverem o gosto pela leitura e incorporarem a utilização da biblioteca em suas aulas. Ressalta que não adianta existirem bibliotecas que não são utilizadas.

Um ponto que pode fortalecer a relação professores/BE é a formação do professor. O professor precisa conhecer o espaço, o acervo, ver as possibilidades de parceria. Imbernón (1994) argumenta que a formação do professor deve ocorrer em sintonia com a forma como o professor deve ensinar. Assim, se o docente aprende a usar os recursos da biblioteca, se percebe como eles podem maximizar a aprendizagem dos estudantes, há mais chances de incorporar o uso dos recursos nas atividades de ensino-aprendizagem.

Nesse contexto, outro fator importante para que haja integração entre docentes e a biblioteca escolar é a presença de bibliotecários e recursos humanos em quantidade suficiente para realizar as atividades. Nos colégios particulares, as bibliotecas estão a cargo de bibliotecários, mas nos demais não há bibliotecários. Também é importante destacar que em todos os colégios a quantidade de funcionários que realizam trabalhos nas bibliotecas escolas não é compatível com a quantidade de estudantes.

No que concerne à formação dos bibliotecários, é necessário que a Faculdade de Ciência da Informação da Universidade de Brasília reveja o próprio currículo, visto que atualmente não há disciplinas obrigatórias voltadas para a realidade das BEs. Mais ainda, em relação à questão da leitura, há necessidade de 
uma alteração profunda. Com certeza, a ausência de conhecimentos básicos atrapalha a atuação dos bibliotecários escolares.

Ao tratar da percepção dos professores sobre a contribuição da BE para os resultados do Enem, observou-se, apesar de vários problemas, a percepção é positiva. Os professores avaliaram positivamente o horário de atendimento e a presença de funcionários competentes no atendimento aos estudantes. Em seguida, os professores avaliaram também positivamente o acervo atualizado, os projetos de leitura e pesquisa, e, por fim, o trabalho integrado da biblioteca com o currículo ou o que eles entendem disso. $O$ fato de a biblioteca oferecer os serviços básicos dão a percepção de integração, que na verdade, é quase inexistente no que concerne aos projetos de leitura.

Isso pode demonstrar o potencial que as BEs possuem para potencializar a aprendizagem. Em 2013, na Escócia, Williams, Wavell e Morrison realizaram uma pesquisa para identificar e avaliar criticamente as evidências disponíveis sobre o impacto das bibliotecas escolares na aprendizagem. Os resultados revelam a existência de um considerável corpo de evidências que demonstram que as bibliotecas escolares contribuem positivamente neste processo. 


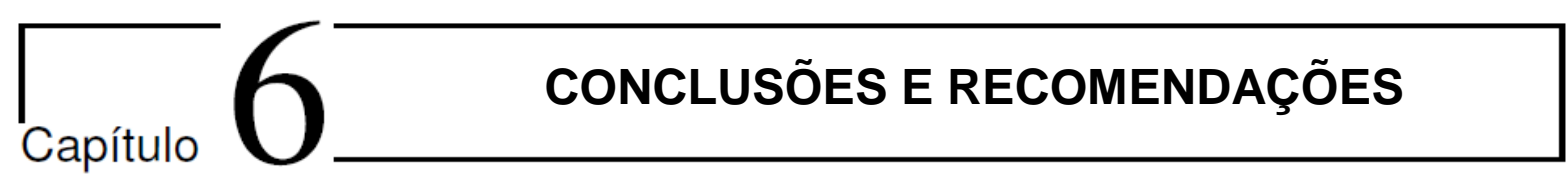

A presente pesquisa buscou analisar a contribuição das bibliotecas escolares nos resultados do Exame Nacional do Ensino Médio considerando os projetos de leitura. Em síntese, os resultados apontaram que os colégios possuem uma estrutura adequada, ainda que haja diferenças grandes entre os particulares e os públicos, em especial, no que concerne à presença das novas tecnologias. As escolas apresentaram uma concepção pedagógica renovada, pelo menos, no discurso, porém apesar de algumas disciplinas complementares no currículo, o ensino-aprendizagem ainda parece ser mais tradicional.

As estruturas das bibliotecas ainda se encontram no patamar básico ou menos. As bibliotecas possuem o mínimo de computadores necessários ao funcionamento, mas não em quantidade suficiente para os estudantes. Foram bem avaliados o acervo, pelo menos, quantitativamente, e o catálogo das bibliotecas, mas os serviços oferecidos são os básicos. Além disso, apesar de metade das bibliotecas contarem com um bibliotecário, a quantidade é insuficiente ao se considerar o número de estudantes.

Os resultados mostraram que os projetos de leitura vinculados às disciplinas, em geral, são realizados sem a participação das bibliotecas escolares. Contudo, os professores relataram que as bibliotecas escolares contribuíram para o resultado do Exame Nacional do Ensino Médio em outros aspectos, tais como, oferecer acesso à informação organizada, propiciar horário de atendimento adequado e recursos humanos.

$E$, por fim, os dados mostram que os professores possuem uma concepção abrangente de biblioteca no discurso, mas isso não se traduz em termos práticos. Além disso, em relação às atividades de leitura em sala de aula, as estratégias ensinadas aos estudantes são as básicas. Os tipos de leitura praticados são a busca de informação e a leitura por prazer, que, no caso, vinculam-se aos estudos literários necessários ao vestibular ou avaliação do Exame Nacional do Ensino Médio.

Assim, retomando a pergunta de pesquisa, pode-se observar que as bibliotecas escolares não contribuíram diretamente para o resultado do Exame Nacional do Ensino Médio em relação aos projetos de leitura, porém contribuíram 
indiretamente por meio dos serviços e produtos oferecidos. Isso significa que as bibliotecas pesquisadas não podem ser consideradas Centros de Recursos de Aprendizagem e não ocupam papel de protagonismo na escola. Portanto, o pressuposto de que o desenvolvimento da competência leitora no processo de letramento informacional realizada nas bibliotecas escolares, em parceria com os docentes, influencia positivamente a aprendizagem dos estudantes não se confirmou nas bibliotecas pesquisadas.

Nesse sentido, pode-se perceber que o espaço físico precisa ser ampliado, o acervo pode ser ampliado e atualizado. Contudo, o mais importante diz respeito à mudança de cultura pedagógica. A comunidade acadêmica precisa realmente se conscientizar que a biblioteca escolar pode desempenhar um papel crucial na aprendizagem, desde que atue como Centro de Recursos de Aprendizagem integrado ao currículo da escola. Por sua vez, as escolas precisam ter currículo mais flexível e voltado para a resolução de problemas. Para que isso ocorra, a formação dos professores e do bibliotecário torna-se elemento essencial, visto que carecem de capacitação, recursos e estratégias para realmente propiciar uma aprendizagem mais significativa.

No que concerne à leitura, as atividades de animação e promoção da leitura são consideradas concepções restritas, que precisam ser ampliadas. Acredita-se que, nos primeiros anos da escola, deveria se consolidar as competências leitoras, estimular o gosto pela leitura e, nos anos seguintes, reforçar essas práticas com atividades de desenvolvimento das competências leitoras voltadas para o pensamento critico.

As propostas pedagógicas das escolas, apesar de especificarem a importância da leitura, possuem lacunas no planejamento e na formação dos mediadores para que realmente ajudem os estudantes a desenvolverem as competências leitoras. Nessa perspectiva, as bibliotecas atuam como atores secundários ou quase inexistentes. Por isso, é necessário o respaldo da proposta pedagógica e o monitoramento para que isso ocorra efetivamente em sala de aula.

Nesse sentido, sugere-se um esquema de trabalho para o planejamento de atividades de leitura integrada ao currículo: 
Figura 04 - Processo de projeto de leitura.

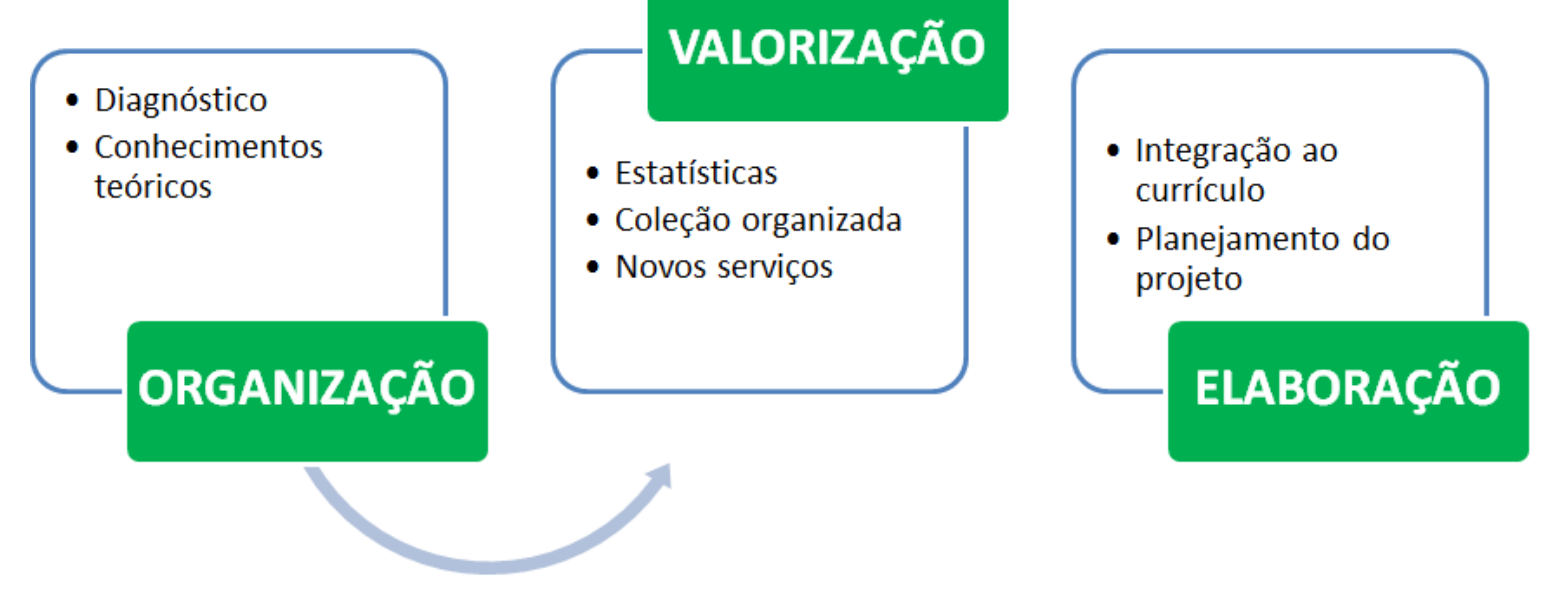

Fonte: elaboração própria.

A figura mostra a existência de três fases, quais sejam: organização, valorização e elaboração. A organização abrange o diagnóstico e os conhecimentos teóricos necessários ao projeto de leitura. Nessa fase, requer-se conhecer a infraestrutura, tipo de coleção, serviços, projetos, recursos humanos, financeiros, parcerias. Além disso, é importante conhecer o paradigma subjacente à concepção da biblioteca. A fase da valorização vincula-se à imagem que a biblioteca reflete. Por isso, a análise dos dados estatísticos e a organização do acervo permitem que se implementem serviços adequados ao perfil e às necessidades da comunidade educacional. Finalmente, a elaboração corresponde ao esboço e apresentação desses resultados e da ideia aos professores, bem como a plena participação dos professores na elaboração do projeto na definição de objetivos, metas, programação das atividades, avaliação e monitoramento.

Observou-se que a realidade das bibliotecas escolares em instituições públicas permitiu verificar na prática a falta de infraestrutura, equipamento, computadores e qualificação contínua dos recursos humanos. Em relação aos profissionais, as informações vão de encontro com a Lei n. 12.244, de 24 de maio de 2010, que menciona, por exemplo, que as bibliotecas escolares devem ser administradas por profissionais com bacharelado em biblioteconomia. No entanto, esse fato por si só não assegura a qualidade das bibliotecas, como se verificou pela 
presença de bibliotecário nas bibliotecas das escolas privadas. Existem outros elementos que influenciam no êxito da biblioteca, como a concepção pedagógica, o tipo de currículo, a formação, dentre vários outros. Assim, é necessário verificar mais profundamente os fatores que impedem a plena integração da biblioteca à estrutura pedagógica.

Um aspecto que pode influenciar positivamente na formação dos bibliotecários é a mudança do currículo das faculdades, assegurando que os graduandos cursem disciplinas obrigatórias voltadas para atuação nas bibliotecas escolares. Por sua vez, os cursos de pedagogia e licenciatura, de maneira geral, precisam proporcionar disciplinas e cursos que ensinem os estudantes a usarem os recursos de informação e a desenvolverem as estratégias de leituras, independente da área, por exemplo, química, matemática, dentre outros. Isso porque a leitura é responsabilidade de todos os membros da sociedade. 


\section{REFERÊNCIAS}

ALFARO, $\mathrm{H}$. Los bibliotecarios y la formación de lectores. Investigación Bibliotecológica. México, v. 23, n. 49, p. 179-196, set./dez., 2009.

ANTUNEZ, J. S. C. Leitura, compreensão e formação do leitor. XVI ENDIPE Encontro Nacional de Didática e Práticas de Ensino. Universidade estadual de Campinas, 2012.

Disponível em:<http://www.infoteca.inf.br/endipe/smarty/templates/arquivos_template/upload_ar quivos/acervo/docs/2338d.pdf>. Acesso em: 29 jan. 2015.

BEHR, Ariel; MORO, Eliane Lourdes da Silva; ESTABEL, Lizandra Brasil. Gestão da biblioteca escolar: metodologias, enfoques e aplicação de ferramentas de gestão e serviços de biblioteca. Ci. Inf., Brasília, v. 37, n. 2, ago. 2008.

BRASIL. Senado Federal. Lei 12.244, de 24 de maio de 2010. Dispõe sobre a universalização das bibliotecas nas instituições de ensino do País. Brasília: Presidência da República, 2010. Disponível em: <http://www.planalto.gov.br/ccivil_03/_Ato2007-2010/2010/Lei/L12244.htm> Acesso em: 30 jan. 2015.

BRASIL. Ministério da Educação/Instituto Nacional de Estudos e Pesquisas Educacionais Anísio Teixeira. Exame Nacional o Ensino Médio: Documento básico. Brasília, $1998 . \quad$ Disponível em: http://historico.enem.inep.gov.br/index.php?option=com_content\&task=view\&id=39\& I temid=73. Acesso em: 21 ago. 2013.

BRASIL. Instituto Nacional de Estudos e Pesquisas Educacionais Anísio Teixeira. Exame Nacional do Ensino Médio (ENEM): fundamentação teórico-metodológica. Brasília: Inep, 2005.

BRASIL. Secretaria de Educação Fundamental. Parâmetros curriculares nacionais : introdução aos parâmetros curriculares nacionais. Secretaria de Educação Fundamental.- Brasília : MEC/SEF, 1997.

BRASIL. Ministério da Educação. Avaliação das Bibliotecas Escolares no Brasil. São Paulo: Edições SM, 2011. 113 p. Disponível em: < http://www.oei.es/bibliobrasil.pdf >. Acesso em: 04 jan. 2015

CAMPELLO, Bernadete (Coord.). Biblioteca escolar como espaço de produção de conhecimento: parâmetros para criação e avaliação de bibliotecas escolares. Belo Horizonte: GEBE, 2010.

Letramento informacional: função educativa do bibliotecário na escola. Belo Horizonte: Autêntica, 2009.

CANTAliCe, L. M. de. Ensino de estratégias de leitura. Psicol. Esc. Educ., Campinas, v. 8, n. 1, jun. 2004. 
CAPURRO, Rafael; HJORLAND, Birger. O conceito de informação. Perspectivas em Ciência da Informação, Belo Horizonte, v. 12, n. 1, p. 148- 207, jan./abr. 2007.

Rafael. Epistemologia e ciência da informação. In: V Encontro Nacional de pesquisa em ciência da informação 2003, Belo Horizonte. Anais. Belo Horizonte: Associação Nacional de Pesquisa e Pós-Graduação em Ciência da Informação e Biblioteconomia, 2003. Disponível em: <www.capurro.de/enancib_p.htm> Acesso em: 13 oct. 2013.

CARVALHO, M. da C. Escola, biblioteca e leitura. In: CAMPELLO, Bernadete et al. A biblioteca escolar: temas para uma prática pedagógica. Belo Horizonte; Autêntica, 2008.

CARVALHO, D. de Q. Bibliotecas Escolares: manual de organização e funcionamento. Rio de Janeiro: FENAME, 1972.

CESILA, J. S. da S. O ensino de literatura no ensino médio: Uma tentativa de aliar o conhecimento ao prazer da leitura. Anais do 17을 Congresso de Leitura do Brasil. Campinas: ALB, 2009.

CERLAC-OEI. Agenda de políticas públicas de lectura: Plan iberoamericano de lectura. Bogotá: CERLAC-OEI, 2004.

CERLAC-Unesco, 2007.

Por las bibliotecas escolares de Iberoamérica. Bogotá:

CONDE, E. Bibliotecas escolares, ambientes de aprendizagem permanentes. Revista Noesis, n. 82, p. 30-31, jul./set. 2010.

CUEVAS, A. Lectura, alfabetizacion en informacion y biblioteca escolar. España: EdicionesTrea, 2007.

SIMEÃO, E. (Coord.). A alfabetização informacional e inclusão digital: modelo de info-inclusão social. Brasília: Thesaurus, 2011.

CUNHA, Murilo Bastos da; CAVALCANTI, Cordélia Robalinho de Oliveira. Dicionário de biblioteconomia e arquivologia. Brasília: Briquet de Lemos Livros, 2008.

DURBAN, G. Programas para el desarrollo de la competencia informacional articulados desde la biblioteca escolar. España: Junta de Andalucía, 2012.

ENEM - EXAME NACIONAL DO ENSINO MÉDIO: Documento básico. MEC/INEP (Ministério da Educação/Instituto Nacional de Estudos e Pesquisas Educacionais Anísio Teixeira); Brasil; $1998 . \quad$ Disponível em: http://historico.enem.inep.gov.br/index.php?option=com_content\&task=view\&id=39\&l temid=73. Acesso em: 21 ago. 2013

FERREIRA, S. P. A.; DIAS, M. da G. B.B. A escola e o ensino da leitura. Psicol. estud., Maringá , v. 7, n. 1, jun. 2002 . Disponível em: 
<http://www.scielo.br/scielo.php?script=sci_arttext\&pid=S1413-

73722002000100007\&lng=pt\&nrm=iso >. Acessos em: 01 ago. 2014.

FOUCAMBERT, J. Leitura em questão. Porto alegre: Artes Médicas, 1994.

FREIRE, Paulo. A importância do ato de ler. Marisa Lajolo (org.) São Paulo: Moderna, 2003.

GASQUE, K. C. G. D. CR: biblioteca escolar para o século XXI. RDBCl, Campinas, SP, v. 11, n. 1, p. 138-154, jan. 2013.

.Competência em informação: Conceitos, características e desafios. AtoZ, Curitiba, v. 2, n. 1, ago. 2013.

Letramento informacional: pesquisa, reflexão e aprendizagem. Brasília: Faculdade de Ciência da Informação/Universidade de Brasília, 2012.

; COSTA, S. M. de S. Comportamento dos professores da educação básica na busca da informação para formação continuada. Ci. Inf., Brasília, v. 32, n. 3, dez. 2003.

GIL, A. C. Estudo de caso: Fundamentação científica, subsídios para coleta e análise de dados, como redigir o relatório. São Paulo: Ed. Atlas, 2009. . Como elaborar projetos de pesquisa. 4. ed. São Paulo: Atlas, 2002.

GALLARDO, S. C. H. El constructivismo social como apoyo en el aprendizaje en línea. Apertura, v. 7(7), p. 46-62, nov. 2007.

HOPKINS, D. M. The School Library Collection: an essential building block to teaching and learning. School Libraries Worldwide, Tallahassee, p. 1-15, vol. 5, 1999.

IMBERNÓN, Francisco. La formación del professorado. Buenos Aires: Paidós, 1994.

INSTITUTO EVARISTE GALOIS. Proposta pedagógica. Disponível em: http://es.scribd.com/doc/235917973/01-Proposta-Pedagogica-Para-2013em\#scribd. Acesso em: 26 nov. 2013.

KRAWCZYK, N. O ensino médio no Brasil. São Paulo: Ação Educativa, 2009.

KOCH, I. V.; ELIAS, V. M. Ler e compreender: Os sentidos do texto. 3. ed. São Paulo: Contexto, 2010.

KUHLTHAU, C. C. O papel da biblioteca escolar no processo de aprendizagem. In: VIANNA, M. M.; CAMPELLO, B.; MOURA, V. H. V. Biblioteca escolar: espaço de ação pedagógica. Belo Horizonte: EB/UFMG, 1999, p. 9-14.

LAKATOS, E. M.; MARCONI, M. de A. Metodologia científica. São Paulo: Atlas, 2011. 
MARCONI, M. de A.; LAKATOS, E. M. Técnicas de pesquisa: planejamento e execução de pesquisas, amostragens e técnicas de pesquisas, elaboração, análise e interpretação de dados. 4.ed. São Paulo: Atlas, 1999.

MARCUSCHI, L. A. Produção textual, análise de gêneros e compreensão. São Paulo: Parábola Editorial, 2012.

MARTINS, M. H.. O que é leitura. Coleção Primeiros Passos, n.ำ 74. São Paulo: Brasiliense, 1994.

MATHEUS, R. F. Rafael Capurro e a filosofia da informação: abordagens, conceitos e metodologias de pesquisa para a Ciência da Informação. Perspectivas em Ciência da Informação, Belo Horizonte. v. 10 n. 2, p.140-165, jul./dez.2005. Disponível em: <http://eprints.rclis.org/7325/>. Acesso em 28 mai. 2013.

MEDEIROS, N. R. D. Enem e a questao da democratização do acesso à graduação: O caso da Unicamp. Brasília, 2002.

MORENO, V. Lectura de prensa y desarrollo de la competencia lectora. Ministerio de Educación/Secretaria General de Educación y Formación Profesional: Madrid, 2009.

MOURA, V. V.. Biblioteca escolar: espaço de ação pedagógica. Belo Horizonte: EB/UFMG, 1999.. Seminário promovido pela Escola de Biblioteconomia da Universidade Federal de Minas Gerais e Associação dos Bibliotecários de Minas Gerais, 1998, Belo Horizonte.

NARANJO; V. E. ¿Debe tener bases pedagógicas el bibliotecólogo dedicado a la promoción de la lectura? Revista Interamericana de Bibliotecología, Medellín, v. 28, n. 1, p. 113-145, jan./jun., 2005.

POZO, J. Aquisição de conhecimento: quando a carne se faz verbo. Porto Alegre: Artmed, 2004.

SANTOS, F. dos; Marques N. J. C; SILVA, E. T da; SANTANNA, F.R de (Org.) Mediação de leitura: discussões e alternativas para a formação de leitores. São Paulo: Global, 2009. 284p.

SANTOS, J. M. C. T. Exame Nacional do Ensino Médio: entre a regulação da qualidade do Ensino Médio e o vestibular. Educação em revista, Curitiba, n. 40, jun. 2011.

SOLÉ, I. Estrategias de lectura. Barcelona: GRAO, 2004.

. Competencia lectora y aprendizaje. Revista Iberoamericana de Educación, n. 59, p. 43-61, 2012. 
THE ORGANISATION FOR ECONOMIC CO-OPERATION AND DEVELOPMENT (OECD). Programme for Internacional Student Asssessment (PISA): Results from PISA 2012. Disponível em: <www.oecd.org/brazil/PISA-2012-results-brazil.pdf.> Acesso em: 15 jun. 2014.

TEBEROSKY, A.; COLOMER, T. Aprender a ler e a escrever: uma proposta construtivista. Porto Alegre: Artmed, 2003.

UNESCO/CERLALC (Centro Regional para el Fomento del Libro en América Latina, el Caribe, España y Portugal). Por las bibliotecas escolares de iberoamérica. Colombia, 2007.

UNESCO; IFLA. Manifesto UNESCO-IFL para biblioteca escolar. 2000. Disponível. $\quad \mathrm{Em} \quad \mathrm{http} / / / \mathrm{www}$. ifla.org/files/assets/school-libraries-resourcecenters/publications/school-library-guidelines/school-library-guidelines-es.pdf.

Acesso em: 16 mar. 2013

WILLIAMS, D.; WAVELL, C.; MORRISON; K. Impact of school library: Critical review of published evidence to inform the work of the Scottish education community. Aberdeen: Robert Gordon University, 2013. 


\section{APÊNDICE \\ QUESTIONÁRIO}

Prezado (a) professor (a),

Este questionário refere-se a uma pesquisa de mestrado do Programa de Pós-Graduação em Ciência da Informação da Universidade de Brasília (UnB). O objetivo é obter dados para analisar a relação entre leitura e biblioteca escolar. Os dados serão mantidos em sigilo. Agradecemos a contribuição.

\section{Sexo}

Feminino

Masculino

\section{Professor (a) em qual área do conhecimento?}

Linguagens e Códigos (Língua Portuguesa, Língua Estrangeira, Arte, Ed. Física)

Matemática

Ciências da Natureza (Ciências, Biologia, Química e Física)

Ciências Sociais (História, Geografia, Filosofia, Sociologia, Ensino Religioso)

\section{Qual é a principal característica da sua concepção de Biblioteca Escolar? Marque somente} uma questão.

Espaço de consulta de livros e documentos $\square$

Espaço de aprendizagem: pesquisa, leitura, eventos culturais.

Espaço de promoção da leitura $\square$

Espaço para guardar informação

\section{Como as atividades de leitura na sua disciplina são planejadas e realizadas?}

\section{Marque somente uma questão.}

Conjuntamente com o bibliotecário e aplicado em parceria

Apenas pelo bibliotecário e aplicadas na biblioteca

Pelo docente e aplicadas na biblioteca $\square$

Pelo docente e aplicadas na sala de aula $\square$

Pelo docente utilizando informação da biblioteca 
5. Marque o tipo de material que costuma indicar aos estudantes para ser consultado na Biblioteca? Qual é a frequência de uso?

\begin{tabular}{|c|c|c|c|c|c|}
\hline 1 & 2 & 3 & 4 & 5 & 6 \\
\hline Nunca & Semanal & Quinzenal & Mensal & Semestral & Anual \\
\hline
\end{tabular}

\begin{tabular}{|l|l|l|l|l|l|l|}
\hline \multicolumn{1}{|c|}{ Materiais de referência: Enciclopédias, } & $\mathbf{1}$ & $\mathbf{2}$ & $\mathbf{3}$ & $\mathbf{4}$ & $\mathbf{5}$ & $\mathbf{6}$ \\
\hline $\begin{array}{l}\text { Obras } \\
\text { Dicionários... }\end{array}$ & & & & & \\
\hline Livros de histórias & & & & & & \\
\hline livros técnicos & & & & & & \\
\hline Revistas, jornais & & & & & & \\
\hline CD-ROM & & & & & & \\
\hline Vídeos; DVD's & & & & & & \\
\hline CD
\end{tabular}

6. Considerando o tipo de texto que você mais trabalha em sala de aula, marque as $\mathbf{5}$ principais estratégias que você utiliza.

\begin{tabular}{|c|c|}
\hline \multirow{8}{*}{ ANTES } & Atividades \\
\hline & Fazer inferências com o título: o que disse? O que sugere? \\
\hline & Relacionar o título com o possível conteúdo. \\
\hline & Formular hipótesis \\
\hline & Ativar conhecimentos prévios (quanto se sabe sobre o texto) \\
\hline & Ensinar o vocabulário necessário \\
\hline & Precisar como ler. Sublinhar. \\
\hline & Constatar a estrutura de textos mediante diagramas. \\
\hline \multirow[t]{5}{*}{ DURANTE } & Reler mediante perguntas explícitas e inferenciais. \\
\hline & Revisar o conteúdo. \\
\hline & Modificar ou confirmar hipóteses. \\
\hline & Aclarar dúvidas de léxico e expressões. \\
\hline & Avaliar o conteúdo e a forma do texto. \\
\hline \multirow{4}{*}{ DEPOIS } & Perguntas literais \\
\hline & Gerar inferências lógicas \\
\hline & Resumir e sintetizar \\
\hline & Generalizar o conhecimento \\
\hline
\end{tabular}


7. Com que frequência, você promove os tipos de práticas de leitura em sala de aula?

\begin{tabular}{|c|c|c|c|c|c|}
\hline 1 & 2 & 3 & 4 & 5 & 6 \\
\hline Nunca & Semanal & Quinzenal & Mensal & Semestral & Anual \\
\hline
\end{tabular}

\begin{tabular}{|l|l|l|l|l|l|l|}
\hline TIPOS DE LEITURA & $\mathbf{1}$ & $\mathbf{2}$ & $\mathbf{3}$ & $\mathbf{4}$ & $\mathbf{5}$ & $\mathbf{6}$ \\
\hline $\begin{array}{l}\text { A leitura - busca de informações. O leitor } \\
\text { extrai do texto uma as mais informações para } \\
\text { responder questões formuladas. }\end{array}$ & & & & & & \\
\hline $\begin{array}{l}\text { A leitura - estudo do texto. O leitor busca } \\
\text { teses, argumentos e verifica-se a coerência } \\
\text { entre tese e argumentos. }\end{array}$ & & & & & & \\
\hline $\begin{array}{l}\text { A leitura do texto - pretexto. Uso do texto } \\
\text { para desenvolver outro produto. Transforma } \\
\text { um poema, dramatiza uma narrativa, produzir } \\
\text { um texto a partir de outro. }\end{array}$ & & & & & & \\
\hline $\begin{array}{l}\text { A leitura - fruição do texto. O prazer de ler, } \\
\text { desinteresse pelo controle do resultado da } \\
\text { leitura. }\end{array}$ & & & & & & \\
\hline
\end{tabular}

8. Quais são as atividades em que a Biblioteca Escolar trabalha em parceria com os professores/ comunidade escolar? E em que frequência essas atividades ocorrem?

\begin{tabular}{|c|c|c|c|c|c|}
\hline 1 & 2 & 3 & 4 & 5 & 6 \\
\hline Nunca & Semanal & Quinzenal & Mensal & Semestral & Anual \\
\hline
\end{tabular}

\begin{tabular}{|l|l|l|l|l|l|l|}
\hline \multicolumn{1}{|c|}{ Atividade } & $\mathbf{1}$ & $\mathbf{2}$ & $\mathbf{3}$ & $\mathbf{4}$ & $\mathbf{5}$ & $\mathbf{6}$ \\
\hline Projetos de leitura & & & & & & \\
\hline Plano semanal (de área/disciplina) & & & & & & \\
\hline Seleção de materiais para a biblioteca & & & & & & \\
\hline Férias e eventos da escola & & & & & & \\
\hline Projetos de pesquisa & & & & & & \\
\hline Formação de profesores & & & & & & \\
\hline Projetos com uso das Tecnologias. & & & & & & \\
\hline Cursos, aulas virtuais & & & & & & \\
\hline Não realiza essas atividades & & & & & & \\
\hline Outras Quais? & & & & & & \\
\hline
\end{tabular}


9. Que tipo de atividade relacionada à leitura se realiza na biblioteca escolar em que trabalha? E com qual frequência essa atividade é feita?

\begin{tabular}{|c|c|c|c|c|c|}
\hline 1 & 2 & 3 & 4 & 5 & 6 \\
\hline Nunca & Semanal & Quinzenal & Mensal & Semestral & Anual \\
\hline
\end{tabular}

\begin{tabular}{|l|l|l|l|l|l|l|}
\hline \multicolumn{1}{|c|}{ Atividade } & $\mathbf{1}$ & $\mathbf{2}$ & $\mathbf{3}$ & $\mathbf{4}$ & $\mathbf{5}$ & $\mathbf{6}$ \\
\hline Hora do conto & & & & & & \\
\hline Exposição de livros & & & & & & \\
\hline Encontros com autores & & & & & & \\
\hline Roda da leitura & & & & & & \\
\hline Clube de leitores & & & & & & \\
\hline Feiras de livros & & & & & & \\
\hline Leitura dialogada & & & & & & \\
\hline Palestras & & & & & & \\
\hline Concursos & & & & & & \\
\hline Pesquisas para as aulas & & & & & & \\
\hline Não realiza essas atividades & & & & & \\
\hline Outra. Qual ?
\end{tabular}

10. Com que frequência utiliza a Biblioteca Escolar? Marque as alternativas conforme opções abaixo:

\begin{tabular}{|c|c|c|c|c|c|}
\hline 1 & 2 & 3 & 4 & 5 & 6 \\
\hline Nunca & Semanal & Quinzenal & Mensal & Semestral & Anual \\
\hline
\end{tabular}

\begin{tabular}{|l|l|l|l|l|l|l|}
\hline \multicolumn{1}{|c|}{ Atividade } & $\mathbf{1}$ & $\mathbf{2}$ & $\mathbf{3}$ & $\mathbf{4}$ & $\mathbf{5}$ & $\mathbf{6}$ \\
\hline Usar o espaço da biblioteca com a turma. & & & & & & \\
\hline Utilizar material bibliográfico para preparar aulas. & & & & & & \\
\hline Empréstimo de Livros. & & & & & & \\
\hline Realizar pesquisa com os estudantes. & & & & & & \\
\hline Complementar ou ampliar a formação docente. & & & & & & \\
\hline Utilizar o espaço para atividades de leitura. & & & & & & \\
\hline Ir a biblioteca com a turma para usar a internet. & & & & & & \\
\hline $\begin{array}{l}\text { Participar de atividades promovidas pela biblioteca } \\
\text { (exposiç̃es, palestras, etc) }\end{array}$ & & & & & & \\
\hline Tirar fotocopias & & & & & & \\
\hline
\end{tabular}


11. Sua escola foi bem avaliada no ENEM, em sua opinião de que maneira a Biblioteca Escolar contribuiu para esse resultado?

\begin{tabular}{|c|c|c|c|c|}
\hline MB & B & R & P & NC \\
\hline Muito Bom & Bom & Regular & Péssima & Não contribuiu \\
\hline
\end{tabular}

\begin{tabular}{|l|l|l|l|l|l|}
\hline \multicolumn{1}{|c|}{ Satisfação } & MB & B & R & P & NC \\
\hline Contribuiu com: & & & & & \\
\hline Ambientes adequados & & & & & \\
\hline Coleção atualizada & & & & & \\
\hline Profissional competente & & & & & \\
\hline Horário amplo de atendimento & & & & & \\
\hline Serviços inovadores & & & & & \\
\hline Atendimento & & & & & \\
\hline Projetos de leitura & & & & & \\
\hline Integração ao currículo & & & & & \\
\hline Trabalho em parceria & & & & & \\
\hline Outros & & & & & \\
\hline
\end{tabular}

MUITO OBRIGADA PELA COLABORAÇÃO. 
ANEXO 1. Parâmetros para bibliotecas escolares

\section{CEBE}

Unlversidade Federal de Minas Gerals

Escola de Clêncla da Informação

Grupo de Estudos en Biblinteca Escolar

\section{Biblioteca escolar como espaço de produção do conhecimento}

Parâmetros para bibliotecas escolares

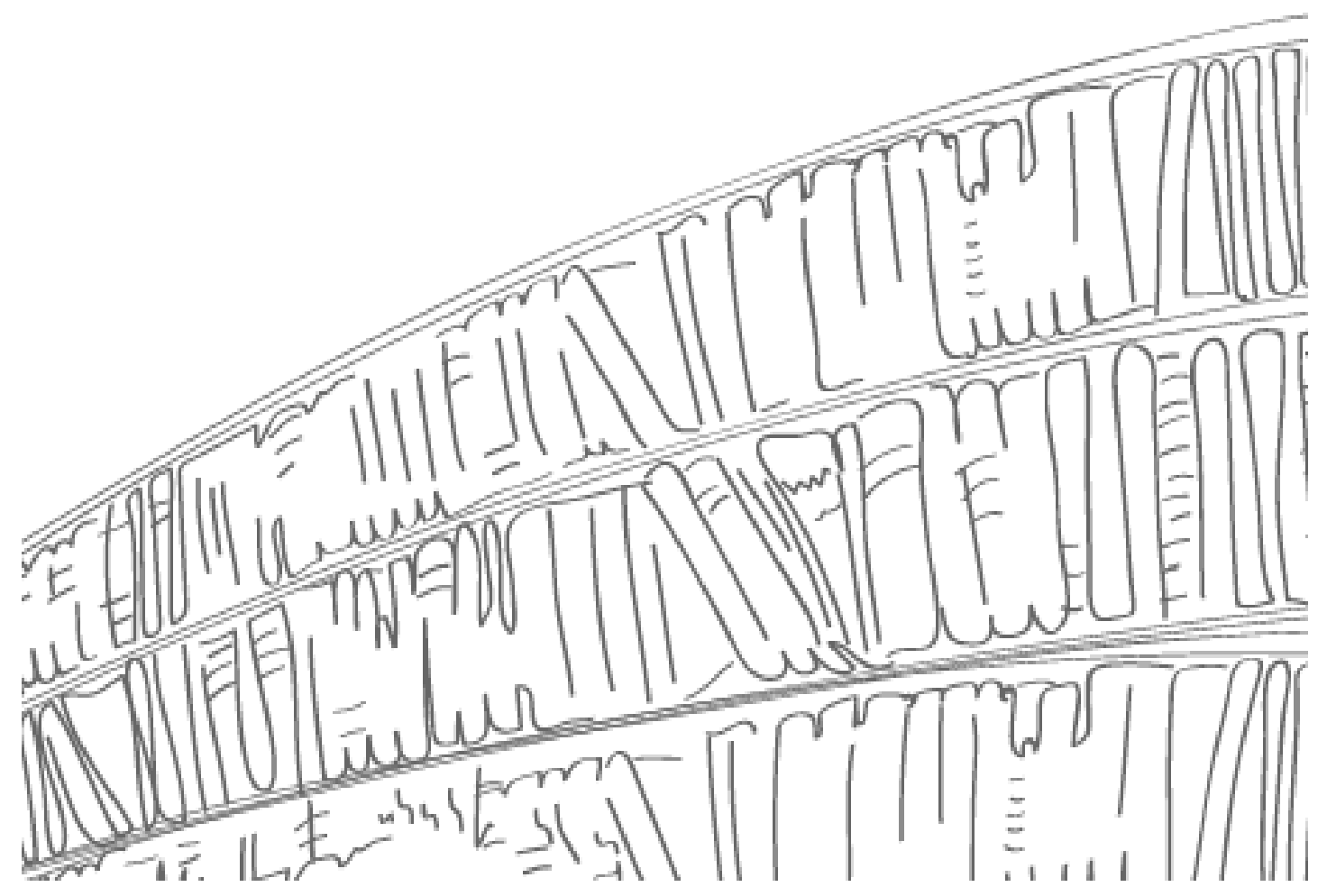


Este instrumento de avaliação e planejamento foi elaborado para permitir que a comunidade escolar elabore um retrato de sua biblioteca ou estabeleça planos para sua criação.A partir daí,é possível traçar metas para seu aperfeiçoamento.

Essas metas devem ser definidas criteriosamente, levando-se sempre em consideração as especificidades da escola e as possibilidades existentes.

Escola:

Biblioteca:

Data da avaliaçẫo: Início

Fim

\section{FUNCIONAMENTO}

Todos os turnos

Apenas um turno

Meta

Ano

\section{Horário de funcionamento}

Regular/durante todo o tempo em que a escola está aberta, inclusive

durante o horário de recreio.

Regular/ durante todo o tempo em que a escola está aberta, menos. durante o horário de recreio

Irregular/ dependendo da disponibilidade de pessoal.

Meta Ano

\section{ESPAÇO FÍsICO}

\section{Localização dentro do espaço da escola}

adequada inadequada

Meta Ano $\mathrm{m} 2$ 
Meta

Ano

Condiçōes de:

$\begin{array}{lcc}\begin{array}{l}\text { Iluminação } \\ \text { Meta }\end{array} & \text { boas } \square & \text { médias } \square \\ \begin{array}{l}\text { Ventilação } \\ \text { Meta }\end{array} & \text { boas } \square & \text { médias } \square \\ \begin{array}{l}\text { Limpeza } \\ \text { Meta }\end{array} & \text { boas } \square & \text { médias } \square \\ \text { Estética } & \text { boas } \square & \text { médias } \square \\ \text { Meta } & \end{array}$

ruins

Ano

ruins

Ano

ruins

Ano

ruins

Ano

Acessibilidade para todas as pessoas

\begin{tabular}{lcc} 
& boas $\square$ & médias $\square$ \\
Meta \\
$\begin{array}{l}\text { Segurança } \\
\text { Meta }\end{array}$ boas $\square$ \\
\hline
\end{tabular}

ruins

Ano

ruins

Ano

Espaços existentes para usuários

Espaço para atendimento ao público m2 nã̀o tem

Meta Ano

Espaço para leitura e pesquisa m2 nã̀ tem

Meta Ano

Espaço específico para leitura infantil m2 กลั้ tem

Meta Ano

Cabines/salas individuais para estudo $\mathrm{m} 2$ naั๊ tem Meta Ano

Espaço para atividades audiovisuais (que exijam equipamento) m2 nằ tem

Meta Ano

Espaço para computadores m2 não tem 
Meta

Ano

Espaço para acervo $\mathrm{m} 2$

não tem

Meta

Ano

Espaços existentes para funcionários $m 2$

atende bem às necessidades

atende razoavelmente às necessidades

não atende às necessidades

Meta

Ano

Mobiliário e equipamentos:

Assentos para acomodar usuários assentos

Meta

Ano

Mesas para acomodar usuários mesas

Meta

Ano

Balcão de atendimento

funcional

pouco funcional

nada funcional nã̃o tem

Meta

Ano

Estantes metros lineares

Acomodam o acervo:

bem

medianamente

mal

Meta

Ano

Guarda volume

tem

naิ̀ tem

Meta

Ano

Estantes expositoras

naิ̀ tem

Meta

tem

Arquivos

tem

naิ̀o tem

Meta

Televisão

tem

nลิ๊o tem

Ano

Ano 
Meta

Ano

Mapoteca

tem

nลิ๊o tem

Meta

Ano

Quadro mural

tem $\square \quad$ nã̃o tem

Meta

nầ tem

Impressora

tem $\square$ nã̃o tem

Meta

tem $\square \quad$ nầo tem

Tocador de DVD

$$
\text { tem }
$$

Meta

\section{năo tem}

Tocador de CD

tem $\square \quad$ não tem

Meta

tem $\square$ (n)

Scanner

tem

nลิ๊ tem

Meta

Ano

Máquina fotográfica tem $\square \quad$ nẫo tem

Meta

te.

Filmadora $\quad$ tem $\square \quad$ não tem $\square$

Meta

$$
\text { ten ธ }
$$

$\begin{array}{lcc}\begin{array}{l}\text { Telefone } \\ \text { Meta }\end{array} & \text { tem } \square & \text { não tem } \square \\ \text { Quadro negro } & \text { tem } \square \\ \text { Meta }\end{array}$

Ano

Ano

Ano

Ano

Layout (Distribuição de espaços, mobiliário e equipamentos) funcional $\square \quad$ pouco funcional $\square$ Meta nada funcional $\square$ Ano 


\section{ACERVO}

Número total de itens do acervo itens

Meta

Ano

Número de títulos títulos

Meta

Ano

Número de itens do acervo destinados a

professores itens

Meta

Ano

Número de itens do acervo destinados a estudantes itens

Meta

Ano

Número de revistas informativas (títulos)

Meta

Ano t__ títulos

Número de jornais (assinaturas correntes) assinaturas de jornais correntes

Meta

Ano

Número de enciclopédias (títulos) enciclopédias

Meta

Ano

Número de dicionários dicionários

Meta Ano

Número de almanaques almanaques

Meta Ano

Outros materiais (gibis, atlas, mapas, DVDs, CDs, fotografias, materiais para contação de histórias, etc. )

em quantidade suficiente

em quantidade insuficiente

Meta

Ano

Número de livros por aluno livros por aluno

Meta Ano

Número total de computadores com acesso à internet 


\section{Computadores}

Relação computador $\mathbf{x}$ alunos

Um computador por alunos

Meta

Ano

Condições de uso dos computadores

boas razoíveis

ruins

Meta

Ano

\section{Condiçōes gerais do acervo}

Equilibrio entre assuntos

Meta \begin{tabular}{c} 
bom $\square \quad$ razoável $\square \quad$ ruim $\square$ \\
\hline
\end{tabular}

Ano

Equilibrio entre séries ou faixa etária dos alunos bom $\square \quad$ razoável $\square \quad$ ruim

Meta Ano

Estado de conservação bom. $\square \quad$ razoível $\square \quad$ ruim

Meta Ano

Freque̊ncia de utilização

Pelos alunos

muito usada

razoavelmente usada

pouco usada

Meta

Ano

Pelos professores

muito usada

razoavelmente usada

pouco usada

Meta

Ano

Número de empréstimos por mês empréstimos

Meta Ano 


\section{Descarte de materiais}

realizado sistematicamente

realizado de vez em quando

nẫo realizado

Meta

Ano

\section{Presença de livros didáticos no acervo da biblioteca}

a biblioteca mantém alguns exemplares apenas para consulta

a biblioteca mantém todos os exemplares que não

foram entregues aos alunos.

Meta Ano

Comissão de seleção do acervo

existe e se reúne regularmente

existe e se reúne raramente

não existe

Meta

Ano

\section{ORGANIZAČ̃O DO ACERVO}

\section{Tombamento/registro}

todo o acervo é tombado/registrado

parte do acervo é tombado/registrado

o acervo nã̃o é tombado/registrado

Meta

Ano

\section{Classificação}

todo o acervo é classificado

parte do acervo é classificado

o acervo não é classificado

Meta

Ano 


\section{Catalogação}

todo o acervo é catalogado

parte do acervo é catalogado

o acervo não é catalogado

Meta

Ano

\section{Informatização do catálogo}

todo o acervo está inserido em catálogo informatizado parte do acervo está inserido em catálogo informatizado não há catálogo informatizado

Meta

Ano

\section{Acesso remoto ao catálogo}

- catálogo de todo o acervo pode ser acessado remotamente

o catálogo de parte do acervo pode ser acessado remotamente o catálogo não pode ser acessado remotamente

Meta

Ano

\section{SERVIÇOS E ATIVIDADES OFERECIDAS}

Consulta no local

Meta

não

$$
\sin
$$

Ano

Empréstimo domiciliar

$\sin$ naิ่

Meta

Ano

Empréstimo manual $\square \quad$ Empréstimo automatizado

Meta

Ano

Orientação individual à pesquisa tem $\square$ nầ tem

Meta

Ano 
Orientação coletiva à pesquisa $\quad$ tem $\square \quad$ não tem

Meta

Ano

Orientação à pesquisa na internet $\operatorname{tem} \square \quad$ nã̃o tem

Meta

Ano

Visitas orientadas

tem $\square$

nã๊o tem [

Meta

Ano

Follheto/guia da biblioteca

tem

não tem

Meta

Ano

Contação de histórias

tem $\square$

nã๊o teก

Meta

Ano

Divulgação de novas aquísiçỗes

tem

nã̃o tem

Meta

Ano

Boletim informativo

tem

nã̃o tem

Meta

Ano

Mural

tem

naี้อ tem

Meta

Ano

Exposiç̧ões

tem

não tem

Meta

Ano

Clube de leitura

tem $\square$

nã̃o tem

Meta

Ano

Feira de livros.

tem

nã๊o tem

Meta

Ano 
Encontro com escritores

Meta

Palestras

Meta

Apresentações artísticas

Meta

Concursos/premiações

Meta

Oficinas

Meta

Blog/site da biblioteca

Meta tem

tem

tem

tem

tem

tem nầ tem

Ano

nâ้o tem

Ano

nẫo tem

Ano

nẫo tem $\square$

Ano

nẫo tem

Ano

nẫo tem

Ano

\section{PESSOAL}

Responsável pela biblioteca

Horas de trabalho que o responsável dedicada à biblioteca

8 a 6 horas diárias

5 a 4 horas diárias

menos de 4 horas diárias

Meta

Ano

Nível de formação do responsável

adequado

pouco adequado

inadequado

Meta

Ano 


\section{Funcionários/auxiliares}

Número de funcionários/auxiliares por turno

$1^{\circ}$ turno _________ funcionários/auxiliares

Meta __ Ano

$2^{\circ}$ turno funcionários/auxiliares

Meta

Ano

$3^{\circ}$ turno ________ funcionários/auxiliares

Meta

Ano

Número total funcionários/auxiliares

Meta Ano

Nível de formação dos funcionários/auxiliares

dequado 
ANEXO 2. Guia da prova de redação do ENEM

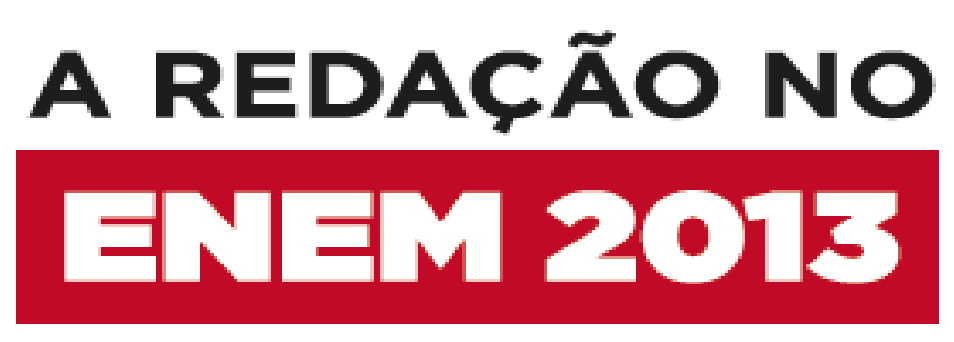

GUIA DO PARTICIPANTE

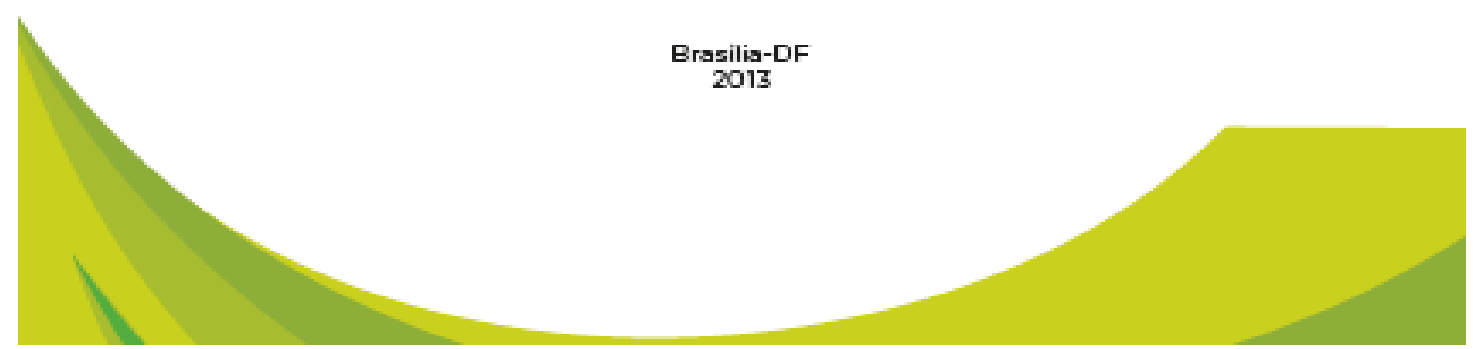




\section{SUMÁRIO}

1 APRESENTAÇĀO.

2 MATRIZ DE REFERÉNCIA PARA REDAÇĀO 2013 - DETALHAMENTO POR COMPETENCIA

2.1 Competência 1 - Demonstrar dominio da modalidade escrita formal da Lingua Portuguesa

2.2 Competência 2 - Compreender a proposta de redaçāo e aplicar conceitos das várias áreas de conhecimento para desenvolver o tema, dentro dos limites estruturais do texto dissertativo-argumentativo em prosa..

2.3 Competẻncia 3 - Selecionar, relacionar, organizar e interpretar informaçōes, fatos, opiniōes e argumentos em defesa de um ponto de vista.

2.4 Competẻncia 4 - Demonstrar conhecimento dos mecanismos linguisticos necessários para a construção da argumentaçăo.

2.5 Competência 5 - Elaborar proposta de intervenção para o problema abordado, respeitando os direitos humanos.

3 PROPOSTA DE REDAÇĀO DO ENEM 2012. 24

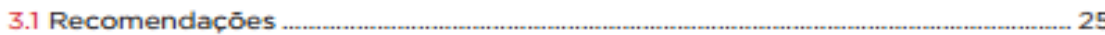

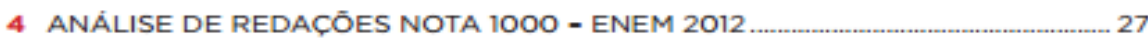

5 LEIA MAIS, SEJA MAIS 


\section{APRESENTAÇÃO}

Caro participante,

Você está se preparando para realizar o Enem 2013, constituído de quatro provas objetivas e uma prova de redação.

A prova de redação exiglrá de vocế a produção de um texto em prosa, do tlpo dissertativo-argumentativo, sobre um tema de ordem soclal, clentíflca, cultural ou politica. Os aspectos a serem avallados relaclonam-se às "competênclas" que devem ter sido desenvolvidas durante os anos de escolaridade. Nessa redação, você deverá defender uma tese, uma opinlão a respelto do tema proposto, apolada em argumentos consistentes estruturados de forma coerente e coesa, de modo a formar uma unldade textual. Seu texto deverá ser redigido de acordo com a modalidade escrita formal da Lingua Portuguesa. Por fim, voce deverá elaborar uma proposta de Intervençăo soclal para o problema apresentado no desenvolvimento

TEMA

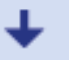

TESE

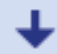

ARGUMENTOS

$\downarrow$

PROPOSTA DE INTERVENÇÃO

Fonte:

http://download.inep.gov.br/educacao basica/enem/guia participante/2013/guia participante redacao enem 2013.pdf. 